UNIVERSIDADE DE SÃO PAULO

FACULDADE DE ECONOMIA, ADMINISTRAÇÃO E CONTABILIDADE DEPARTAMENTO DE ADMINISTRAÇÃO

PROGRAMA DE MESTRADO PROFISSIONAL EM EMPREENDEDORISMO

LUIS FERNANDO OLIVEIRA RODRIGUES

A REINVENÇÃO DE UMA EMPRESA DE COBRANÇA EDUCACIONAL: EMPRESA CAMARGO RODRIGUES

Orientador: PROF. DR. MARTINHO ISNARD RIBEIRO DE ALMEIDA

São Paulo 
Prof. Dr. Vahan Agopyan

Reitor da Universidade de São Paulo

Prof. Dr. Fábio Frezatti

Diretor da Faculdade de Economia, Administração e Contabilidade

Prof. Dr. Moacir de Miranda Oliveira Junior

Chefe do Departamento de Administração

Prof. Dr. Marcelo Caldeira Pedroso

Coordenador do Programa de Mestrado Profissional em Empreendedorismo 


\title{
A REINVENÇÃO DE UMA EMPRESA DE COBRANÇA EDUCACIONAL: EMPRESA CAMARGO RODRIGUES
}

\begin{abstract}
Dissertação apresentada ao Programa de Mestrado Profissional em Empreendedorismo do Departamento de Administração da Faculdade de Economia, Administração e Contabilidade da Universidade de São Paulo, como requisito parcial para obtenção do título de Mestre em Ciências.
\end{abstract}

Orientador: Prof. Dr. Martinho Isnard Ribeiro de Almeida

Versão corrigida

\section{SÃO PAULO}


Ficha Catalográfica

Elaborada pela Seção de Processamento Técnico do SBD/FEA com os dados inseridos pelo(a) autor(a)

Rodrigues, Luis Fernando Oliveira.

A reinvenção de uma empresa de cobrança educacional: empresa Camargo Rodrigues / Luis Fernando Oliveira Rodrigues. - São Paulo, 2019. $115 \mathrm{p}$.

Dissertação (Mestrado) - Universidade de São Paulo, 2019.

Orientador: Martinho Isnard Ribeiro de Almeida.

1. Empreendedorismo. 2. Cobrança educacional. 3. Compra de recebíveis. I. Universidade de São Paulo. Faculdade de Economia, Administração e Contabilidade. II. Título. 


\section{DEDICATÓRIA}

À minha esposa, Claudia Camargo, aos meus filhos, Gabriela Rodrigues e Felipe Rodrigues, pelo suporte e incentivo neste longo caminho.

Ao meu pai, Clésio Teixeira Rodrigues, pelos exemplos dados em sua curta jornada entre nós, e, principalmente, à minha mãe, Maria Helena Rodrigues, por sua admiração e grande torcida por mim.

Ao meu orientador e amigo Martinho Isnard Ribeiro de Almeida, um grande estrategista empresarial, por sua eterna disposição em me orientar com carinho e humildade desde 1996. 



\section{AGRADECIMENTOS}

Inicialmente, agradeço a Deus por estar sempre ao meu lado.

Agradeço à minha esposa e aos meus filhos, pois eles são a principal motivação para que eu siga em frente com entusiasmo e amor.

Agradeço aos meus pais e aos meus irmãos pela confiança que sempre tiveram em mim. Agradeço à família da minha esposa por sempre bridarem gentilmente comigo as vitórias.

Agradeço ao meu amigo e cliente Carlos Eduardo Amorim, diretor Geral das Faculdades Oswaldo Cruz, por ter acreditado em mim antes mesmo de me conhecer.

Agradeço ao meu amigo, professor, orientador, consultor e mentor Prof. Martinho Isnard Ribeiro de Almeida, por me atender e aconselhar de forma incansável e com uma disposição invejável.

Agradeço à Fabiana, secretária do curso, por esclarecer todas as dúvidas que tive com um largo sorriso no rosto.

Agradeço à Professora Heidy e ao Professor Reynaldo pelas valiosas orientações dadas na fase de qualificação.

Agradeço a todos os professores do programa do mestrado profissional pelos ensinamentos passados durante o curso.

Agradeço, sobretudo aos meus colegas de sala, por todas as colaborações e observações que fizeram ao meu trabalho.

Agradeço ao matemático Ivan Ferraz pelo apoio na elaboração dos cálculos de precificação do serviço ora desenvolvido.

Agradeço a todos os colaboradores que trabalham em minhas empresas, pois sem eles eu não estaria onde estou e nem teria feito os cursos que fiz. Pessoal, muito obrigado! 

Existem dois tipos de empresários,

os ágeis e os que já morreram!

(Autor desconhecido)

Luis Fernando Rodrigues 



\section{APRESENTAÇÃO}

Meu nome é LUIS FERNANDO OLIVEIRA RODRIGUES, sou advogado e me formei na PUC-SP em 1990 com a ajuda de minha mãe e de meu avô, Caetano Bertino de Almeida Oliveira, que era dentista aposentado. Tenho 53 anos e sou empreendedor desde os 14 anos de idade, quando vendia pulseirinha de linha no colégio, depois óculos espelhados no colegial, e depois sanduíche natural no cursinho. Como autônomo, fui também professor de iatismo no tempo de faculdade, até iniciar os estágios de Direito. Como estagiário, trabalhei em três empresas, a saber: Bandeira de Melo \& Nahun Advogados, Indústrias Villares e Alcoa Alumínio. Em 1989, morei na Inglaterra para aperfeiçoar o inglês e acabei também me certificando como instrutor sênior de iatismo pela Royal Yachting Association. Em 1991 montei minha primeira empresa formal, a BL3 Escola de Iatismo, em sociedade com o meu irmão gêmeo, Pedro Luis Oliveira Rodrigues. Iniciei a profissão como advogado aos 28 anos, em 1994, trabalhando por dois anos em processos de abertura de novos cursos junto ao MEC, em Brasília. A oportunidade me foi dada por um aluno da BL3 que trabalhava nas Faculdades Oswaldo Cruz. Em 1996 montei a CAMARGO RODRIGUES e comecei a cobrar os alunos inadimplentes dessa instituição de ensino superior. Para constituir a empresa de cobrança educacional, busquei os conselhos do meu irmão mais velho, já falecido, Clésio Roberto Oliveira Rodrigues, do Professor Martinho Isnard Ribeiro de Almeida e, também, de dois contadores amigos deles, Marcos Luchinni e Flávio Mattos. O fato é que, nestes 23 anos de empresa, sempre procurei manter-me atualizado, conversando com especialistas e fazendo diversos cursos, como a pós-graduação em Direito Educacional, MBA Executivo no Insper e pós-graduação em Direito Tributário, para gerir a empresa da melhor forma possível e poder crescer. Em 2016, diante das dificuldades que a empresa vinha enfrentando, o Professor Martinho sugeriu que eu fizesse o Mestrado Profissional, algo que também era meu sonho. Prestei as provas, passei e acabei vindo, mais uma vez, beber água na fonte para me atualizar e, quem sabe, retomar o crescimento de minha empresa. Além disso, sentia que como empreendedor precisava me adaptar ao mercado atual, que vinha sofrendo transformações profundas ano após ano. O curso poderia me auxiliar a diagnosticar melhor as causas das dificuldades pelas quais a empresa vinha passando. Em suma, 
aprendi muito ao longo dos dois anos de curso, desde o contrato psicológico de trabalho, até o fim do emprego, passando por Canvas, Design Thinking, Modelo de negócios e Empreendedorismo social. Saio renovado, reinventado, reformado, atualizado, com um novo repertório e, principalmente, com uma nova proposta de prestação de serviços. Sinto-me pronto para retomar o crescimento e, sobretudo, para ofertar à sociedade mais empregos através de uma empresa ainda mais preparada para enfrentar os desafios do futuro. 


\section{RESUMO}

A presente pesquisa tomou como base a vivência do autor em sua empresa de cobrança educacional, a CAMARGO RODRIGUES. A empresa foi constituída em 1996 com o objetivo de cobrar mensalidades atrasadas de Instituições de Ensino Superior Privadas. Ocorre que, a partir de 2009, a empresa começou a perder receita em razão de diversos fatores, sendo os quatro principais: a concorrência, a concentração do setor educacional, cobrança interna pelo cliente e o fundo de financiamento estudantil - FIES. Naquele momento, a alternativa encontrada para compensar as perdas de receita foi constituir a RAF Advogados, para realizar a cobrança judicial dos débitos que permaneciam em aberto após a cobrança amigável, agregando valor ao serviço de cobrança educacional extrajudicial. Entretanto, a partir de 2016 a empresa voltou a ter problemas de receita em razão do aumento do desemprego decorrente da crise no governo Dilma. Com isso o problema a ser resolvido era: Como retomar o crescimento da Camargo Rodrigues. Após realizar pesquisa pelo método de pesquisa-ação, como solução, os estudos revelaram que a empresa precisava se reinventar criando um novo serviço. Dessa forma, criou-se um novo serviço: a compra de recebíveis vencidos há mais de 90 dias. Este novo serviço foi desenvolvido em cima de uma carteira de 2014 que já havia cumprido todo o ciclo de cobrança amigável e judicial. O modelo de precificação foi calculado por um matemático que considerou diversas variáveis, como o tempo de cobrança amigável e de cobrança judicial, taxas de recuperação, taxas de inadimplência, custos de cobrança amigável e judicial e uma taxa de retorno adequada sobre o capital, o que possibilitou chegar a um percentual para a compra dessas carteiras de mensalidades vencidas. Após validação com os dois principais clientes, concluímos que o estudo foi fundamental por que orientou a negociação com os clientes, pois, quando o novo serviço foi apresentado a dois clientes que o aceitaram de imediato, houve um cliente que queria receber um valor muito alto que comprometeria o retorno e o negócio não se concretizou. Notou-se, então, que a negociação deste novo serviço não será fácil, ainda mais porque o valor final terá de ser menor que o percentual apurado para que haja ganho financeiro além do ponto de equilíbrio. Ademais, o estudo demonstrou que o risco neste tipo de operação é alto, pois o devedor está mais resistente à cobrança. E ainda existem os riscos decorrentes da situação econômica.

Palavras-chave: Cobrança educacional, Compra de recebíveis. 



\begin{abstract}
This research was based on the author's experience in his educational collection company, CAMARGO RODRIGUES. The company was incorporated in 1996 with the purpose of charging late tuition from Private Higher Education Institutions. As of 2009, the company started to lose revenue due to several factors, being the four main ones: competition, concentration of the education sector, internal collection by the client and the student financing fund - FIES. At that time, the alternative found to compensate for the loss of revenue was to set up RAF Advogados, to make the judicial collection of debts that remained open after the friendly collection, adding value to the extrajudicial educational collection service. However, from 2016 the company had again revenue problems due to the increase in unemployment due to the crisis in the Dilma government. With this the problem to be solved was: How to resume the growth of Camargo Rodrigues. After researching the action research method as a solution, studies revealed that the company needed to reinvent itself by creating a new service. Thus, a new service was created: the purchase of receivables overdue for more than 90 days. This new service was developed on top of a 2014 portfolio that had already completed the entire friendly and judicial collection cycle. The pricing model was calculated by a mathematician who considered several variables, such as amicable and judicial collection time, recovery rates, default rates, amicable and judicial collection costs, and an adequate rate of return on capital. which made it possible to reach a percentage for the purchase of these overdue monthly loan portfolios. After validation with the two main clients, we concluded that the study was fundamental because it guided the negotiation with the clients, because when the new service was presented to two clients who immediately accepted it, there was one client who wanted to receive a very high value. that would compromise the return and the deal did not materialize. It was noted, then, that the negotiation of this new service will not be easy, especially since the final value will have to be less than the percentage calculated for financial gain beyond the break-even point. In addition, the study showed that the risk in this type of operation is high because the debtor is more resistant to recovery. And there are still risks arising from the economic situation.
\end{abstract}

Keywords: Educational collection, Purchase of receivables. 



\section{LISTA DE ABREVIATURAS E SIGLAS}

ACSP

$\mathrm{B} 2 \mathrm{~B}$

BNDES

CAPES

CDC

$\mathrm{CF}$

$\mathrm{CPC}$

CR

CREV

ERP

FIES

FOFA

IESP

IBGE

IPCA

INEP

NCC

PIB

RAF

TI
Associação Comercial de São Paulo

Business to Business

Banco Nacional de Desenvolvimento Econômico e Social

Coordenação de Aperfeiçoamento de Pessoal de Nível Superior

Código de Defesa do Consumidor

Constituição Federal

Código de Processo Civil

Camargo Rodrigues Assessoria em cobranças

Compra de Recebíveis Educacionais Vencidos

Enterprise Resource Planning

Fundo de Financiamento Estudantil

Pontos fortes, Oportunidades, Pontos fracos e Ameaças

Instituição de Ensino Superior Privada

Instituto Brasileiro de Geografia e Estatística

Índice de Preços ao Consumidor Ampliado

Instituto Nacional de Estudos e Pesquisas Educacionais

Novo Código Civil

Produto Interno Bruto

Rodrigues, Abud, Ferreroni Advogados Associados

Tecnologia da Informação 



\section{LISTA DE TABELAS}

Tabela 1 - Educação Superior Brasil 2017

Tabela 2 - Causas da inadimplência educacional

Tabela 3 - Crescimento nos 5 primeiros anos

Tabela 4 -: Fases do grupo CAMARGO RODRIGUES

Tabela 5 - Análise SWOT ou FOFA

Tabela 6 - Linha do tempo das empresas

Tabela 7 - Entrevistas realizadas

Tabela 8 - Fases de cobrança

Tabela 9 - Quadro dos serviços prestados atualmente e o novo serviço

Tabela 10 - Status de débito

Tabela 11 - Taxa de retorno sobre o capital 



\section{LISTA DE FIGURAS}

Figura 1 - Variação anual do IPCA

Figura 2 - Número de alunos matriculados nas IES Privadas

Figura 3 - Três Estratégias Genéricas

Figura 4 - Receita Bruta CAMARGO RODRIGUES de 1997 a 2018

Figura 5 - SWOT com Canvas

Figura 6 - Receita Bruta RAF de 2009 a 2018

Figura 7 - Matriz ciclo de vida das organizações

Figura 8 - Receita Bruta CAMARGO, RAF e TOTAL 53

Figura 9 - Evolução do PIB do Brasil de 2011 a 2018

Figura 10 - Diagrama de causa e efeito

Figura 11 - Estrutura da dissertação

Figura 12 - Problema, repertório e solução

Figura 13-Formas de crescer

Figura 14 - Espiral de reflexão

Figura 15 - Diagrama de influência

Figura 16 - Fluxo de caixa dos 7 primeiros meses 



\section{ANEXOS}

Anexo 1 - Premissas iniciais para cálculo do fluxo de caixa

Anexo 2 - Valores históricos de mensalidades em aberto

Anexo 3 - Valor presente, Cenário e Custos

109

Anexo 4 - Receitas

111

Anexo 5 - Minuta de Contrato de Cessão de Crédito Educacional

113 



\section{SUMÁRIO}

1- INTRODUÇÃO

1.1- Contextualização 30

1.2- Cobrança amigável 36

1.3- A Estratégia 39

1.4- O declínio da cobrança amigável 42

$\begin{array}{ll}1.5- & \text { Cobrança judicial }\end{array}$

1.6- O ciclo de vida das empresas $\quad 50$

2- O PROBLEMA

2.1- Analise SWOT 55

2.2- Aspectos internos 56

2.3- Ambiente organizacional 57

2.4- Problema observado 61

2.5- Questão de pesquisa $\quad 62$

2.6- Objetivos 62

2.6.1- Objetivo principal 63

2.6.2- Objetivos complementares 63

2.6.3- Estrutura da dissertação 64

3- REFERENCIAL TEÓRICO 67

3.1- Planejamento estratégico 67

3.2- Busca da Liderança 69

$\begin{array}{ll}3.3-\text { Relacionamento com clientes } & 70\end{array}$

3.4- Conhecendo o problema $\quad 71$

$\begin{array}{ll}3.5-\text { Visão de um futuro inovador } & 72\end{array}$

3.6- Reconhecimento de oportunidade $\quad 73$

$\begin{array}{ll}\text { 3.7- Lei 9870/99 } & 74\end{array}$

3.8- A solução 74

4- MÉTOdOS E TÉCNICAS DE PESQUISA

4.1- Pesquisa-ação $\quad 77$

4.2- Espiral de reflexão $\quad 78$

$\begin{array}{ll}\text { 4.3- Pesquisa exploratória qualitativa } & 79\end{array}$ 
5.1- Compra de recebíveis educacionais vencidos

5.2- Modelo de precificação

5.3- Metodologia

5.3.1 - Na cor rosa

5.3.2- Na cor azul 88

5.3.3- Na cor lilás 88

5.3.4- Na cor verde 88

5.4 - Validação 92

6- CONCLUSÕES E LIMITAÇÕES DA PESQUISA 95

7- REFERÊNCIAS BIBILIOGRÁFICAS 99

8- BIBLIOGRAFIA COMPLEMENTAR 103

9- ANEXOS 


\section{1- INTRODUÇÃO}

A inadimplência educacional surgiu de forma mais contundente no Brasil em meados do ano de 1994, após a estabilização da economia, decorrente da implantação do Plano Real. Nesse momento, as instituições de ensino particulares, principalmente as Instituições do Ensino Superior Privado (IESP), passaram a identificar a existência de índices de inadimplência extremamente altos, que passaram a comprometer a saúde financeira das IESP.

Piorou essa situação o fato de o governo ter incentivado a abertura de novos cursos, pois a procura por cursos universitários era maior do que o número de vagas disponíveis, ou seja, a demanda de alunos era maior que a oferta de vagas, pois havia um grande funil, e as poucas vagas existentes eram muito concorridas pelos alunos que se inscreviam nos vestibulares.

Em razão desses incentivos, o número de alunos cresceu bastante e, junto com ele, a inadimplência educacional, que aumentou mais ainda e continuou crescendo até o ano de 2015, como se verá nos próximos itens.

Em face dessa situação, surgiu a oportunidade de constituir uma empresa de cobrança educacional, ou seja, de constituir uma empresa de cobrança que fosse especializada na recuperação das mensalidades vencidas de instituições de ensino privadas.

Nesse contexto, nasceu a empresa de cobrança especializada em cobrança educacional - a CAMARGO RODRIGUES -, constituída em 1996 com o propósito de reduzir a inadimplência dos estabelecimentos de ensino privados. A empresa foi criada com uma estratégia clara de diferenciação em relação ao mercado tradicional de cobrança. Pode-se considerar que o serviço se classificava como alvo estreito, pois buscava prestar o melhor serviço exclusivamente ao setor educacional.

Como estratégia, desenvolveu-se um serviço diferenciado, como se verá, que sempre procurou obter uma solução amigável com o devedor, buscando, inicialmente, conversar com ele, tratando-o com respeito e dignidade, ao invés de, como tradicionalmente se fazia, tratá-lo como estelionatário. $\mathrm{O}$ atendimento era feito em um 
local fora da escola, evitando-se assim constrangimentos ao aluno perante seus amigos, professores e funcionários.

Enfim, buscou-se criar algo único dentro da indústria educacional, fugindo do padrão de cobrança tradicional, que se utiliza do telemarketing acentuadamente e, sobretudo, oferece um atendimento grosseiro e intimidador.

Anos depois, a empresa começou a ser copiada pela concorrência. Basicamente, a concorrência era composta, em sua grande maioria, de diversos tipos de empresas, como: outras empresas de cobrança, escritórios de advocacia e também escritórios de contabilidade que prestavam assessoria a instituições de ensino, além de outras empresas que porventura tivessem algum tipo de relacionamento com as IESP.

Em razão dessa concorrência voraz, o serviço deixou de ser diferenciado, pois muitas empresas copiaram o modelo de negócios desenvolvido pela CAMARGO RODRIGUES, assim como a política de cobrança criada pela empresa, que tinha desenvolvido uma nova forma de tratar o devedor. Com isso, o serviço prestado deixou de ser inédito, o que obrigou a empresa a modificar sua estratégia, que passou a focar em preço e não mais em diferenciação. O serviço passou a ser baseado estritamente no preço, com uma estratégia mais focada em custo. Tal mudança de estratégia gerou uma perda significativa de margem, reduzindo os lucros auferidos pela empresa. Basicamente, pode-se afirmar que houve, com o passar dos anos, uma comoditização do serviço de cobrança educacional, haja vista que as IESP passaram a buscar mais por preço do que por qualidade, mudando completamente seus critérios de escolha na hora da contratação de uma empresa de cobrança.

Além da concorrência, outros fatores também contribuíram para o declínio da empresa, como a concentração do setor educacional do ensino superior privado, os avanços tecnológicos e o Financiamento ao Estudante do Ensino Superior Privado. Em razão desses fatores, em meados de 2009 a empresa decidiu iniciar um novo serviço, qual seja, realizar a cobrança judicial, constituindo para isso um escritório de advocacia, RODRIGUES ABUD FERRERONI ADVOGADOS (RAF ADVOGADOS), que foi concebido para compensar as perdas de receita ocorridas e gerar uma segunda onda de crescimento, pois a empresa de cobrança amigável estava sofrendo demais com a perda de receita. 
Como na CAMARGO RODRIGUES, o escritório de advocacia adotou como estratégia competitiva atuar focando um alvo estreito, a fim de obter retornos acima da média por meio da diferenciação com foco em qualidade na cobrança judicial de mensalidades vencidas das IESP.

Constituir a RAF ADVOGADOS mostrou ser uma estratégia acertada e, para melhorar a situação, logo após a sua montagem houve a criação dos setores de conciliação pelo Poder Judiciário, o que ocorreu devido à publicação do novo CPC no ano de 2015. Também houve alterações na lei processual civil que favoreceram a cobrança judicial, como as que permitiram a "penhora on-line".

A penhora on-line é um expediente realizado diretamente pelo juiz de direito a pedido do credor sem a necessidade de expedição de ofícios aos Bancos, pois é realizado eletronicamente, caso em que o devedor não toma ciência antes do bloqueio dos valores eventualmente depositados em sua conta bancária, como antigamente.

Contudo, novamente, alguns anos depois, o escritório de advocacia que realizava a cobrança judicial entrou em declínio. Os fatores foram semelhantes aos que levaram ao declínio da empresa que realizava a cobrança amigável, haja vista que as duas empresas tinham o mesmo propósito, reduzir a inadimplência educacional.

O fato é que 2012 foi o pior ano da história da empresa, que permaneceu em declínio até o ano de 2016, quando então passou-se a buscar uma nova solução para os problemas de receita que novamente se tornaram presentes.

A solução encontrada foi explorar o problema no Mestrado Profissional. Ao longo do curso, concluiu-se que a solução poderia ser lançar um novo serviço, algo que fosse inédito e inovador, visando novamente alcançar resultados positivos que possibilitassem a expansão da empresa.

Acredita-se que este novo serviço, eventualmente, possibilitará a retomada do crescimento da empresa de cobrança educacional que realiza a cobrança extrajudicial através da CAMARGO RODRIGUES e a cobrança judicial através da empresa RAF ADVOGADOS. 


\section{1- CONTEXTUALIZAÇÃO}

A estabilização da economia, patrocinada pelo Plano Real nos governos de Itamar Franco e Fernando Henrique Cardoso em 1994, acabou com a inflação e introduziu o país em um novo ciclo de crescimento econômico.

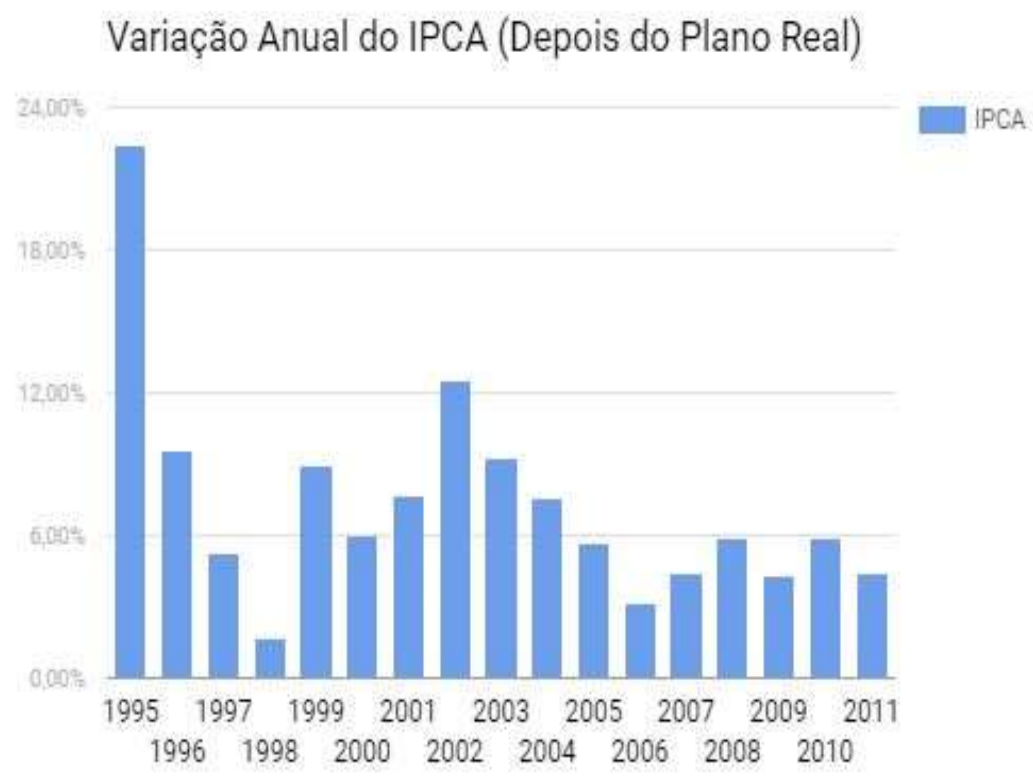

Figura 1 - Variação anual do IPCA

Fonte: IBGE, Diretoria de pesquisas, Coordenação de índices de preços, Sistema Nacional de Índices de Preços ao Consumidor. Disponível em:

$<$ https://www.google.com/search?biw=1366\&bih=590\&tbm=isch\&sa=1\&ei=y62rXK3wNaCr5OUPib2p $6 \mathrm{Ag} \& \mathrm{q}=$ varia $\% \mathrm{C} 3 \% \mathrm{~A} 7 \% \mathrm{C} 3 \% \mathrm{~A} 3 \mathrm{o}+$ anual + do + ipca\&oq $=$ varia $\% \mathrm{C} 3 \% \mathrm{~A} 7 \% \mathrm{C} 3 \% \mathrm{~A} 3 \mathrm{o}+$ anual + do + ipca $\& \mathrm{gs}$ $\mathrm{l}=$ img.1.0.0i24.55658.58555..60388...0.0..0.95.555.6..........1..gws-wiz-img.k6INmR9cw1 A\#imgrc=dzjKKTLJ50WkM>. Acesso em: 2018.

Nesse contexto de estabilização econômica, o setor educacional do ensino superior privado começou, com a chancela do governo, a aumentar a oferta de vagas em diversos cursos para, sobretudo, atender à enorme demanda reprimida de brasileiros que ansiavam fazer um curso superior e não conseguiam, pois o número de vagas existentes à época era inferior ao número de brasileiros que queriam fazer uma graduação e estudar no ensino superior. 
Desde que se iniciou este movimento de aumentar o número de vagas no ensino superior privado, o número de alunos matriculados passou de 1 milhão em 1995 para mais de 5 milhões de alunos matriculados em 2015 (Fig. 2), uma expansão de mais de $500 \%$ em 20 anos. Isso permitiu que muitos brasileiros conseguissem realizar o grande sonho de fazer um curso superior, principalmente os brasileiros advindos das classes $\mathrm{C}$ e $\mathrm{D}$, pois estes eram os que encontravam maior dificuldade de acesso ao ensino superior, por terem estudado, em sua grande maioria, em escolas públicas, o que dificultava ainda mias o acesso ao ensino superior, pois as escolas públicas, que notoriamente perderam muito em qualidade nas últimas décadas para as escolas particulares.

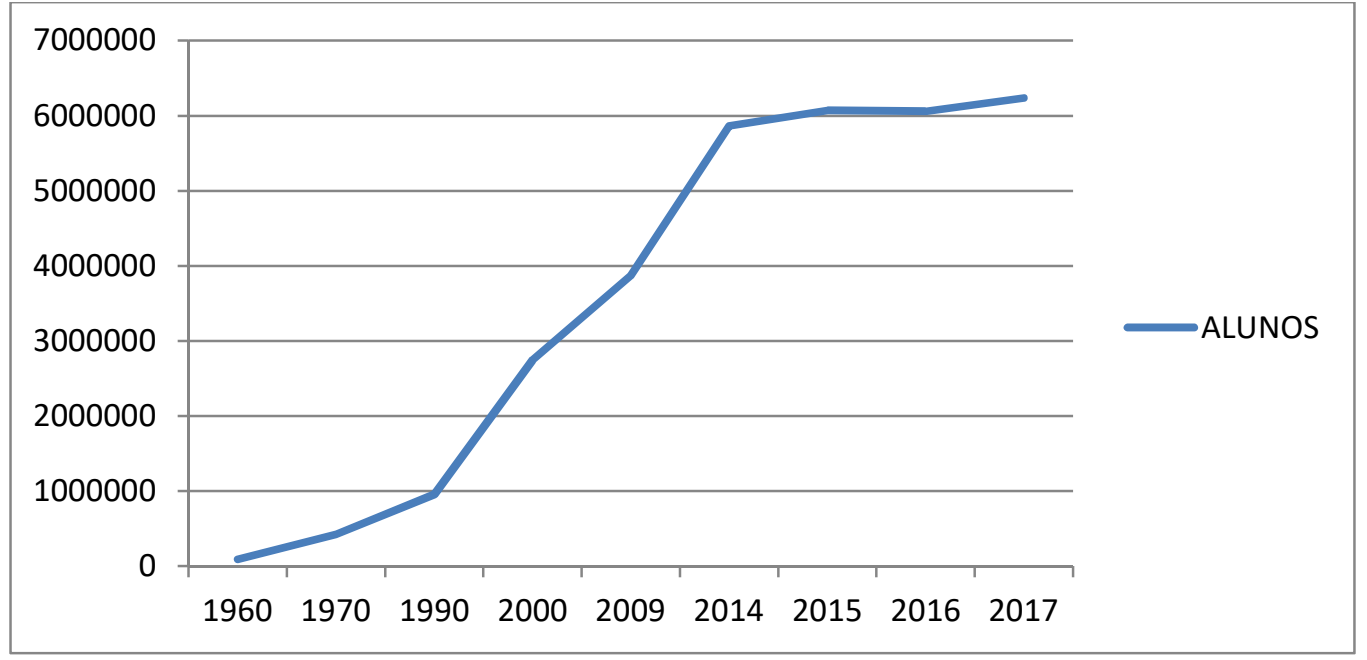

Figura 2 - Número de alunos matriculados nas IES Privadas

Fonte: INEP/MEC (2017). (Atualizado até 20/09/2018).

Junto com a estabilização da economia e com a expansão do número de alunos no ensino superior privado, porém, aumentou significativamente a inadimplência, que chegou a ser de mais de 40\% em algumas Instituições de Ensino Superior Privadas, conforme informado pelos clientes a época, em razão do fato de estes novos alunos serem de baixa renda, das classes mais desfavorecidas, e advindos de instituições públicas, que apresentam baixa qualidade de ensino. 
No Brasil, segundo relatório do INEP de 2017 publicado em 20/09/2018, aproximadamente 27.348.080 alunos estão matriculados na educação básica, dos quais $83,16 \%$ (22.742.259) estudam em escolas públicas e 16,84\% (4.605.821) em escolas particulares. O mesmo relatório indicou que somente 8.286 .663 jovens (ou 30\%) estão na universidade. Mas no ensino superior a maioria dos jovens estuda em Universidades particulares $75,3 \%(6.241 .307)$ e a minoria em universidades públicas $24,7 \%$ (2.045.356), como a Universidade de São Paulo.

Tabela 1 - Educação Superior Brasil 2017

\begin{tabular}{|c|c|c|c|}
\hline GRADUAÇÃO & Pública & Particular & Total \\
\hline Matrículas & 2.045 .356 & 6.241 .307 & 8.286 .663 \\
\hline$\%$ & $24,7 \%$ & $75,3 \%$ & $100 \%$ \\
\hline Nr de Instituições & 296 & 2.111 & 2.407 \\
\hline$\%$ & $12,30 \%$ & $87,70 \%$ & $100 \%$ \\
\hline
\end{tabular}

Fonte: INEP/MEC. Censo Educação Superior (2017). (Atualizado até 20/09/2018).

Disponível em: http://www.brasil.gov.br/noticias/educacao-e-ciencia/2017/08/ensino-superior-tem-8-05milhoes-de-alunos-matriculados-em-2016/universitarios_unb_ebc.jpg/view

Com o passar do tempo, foi ficando claro que estes alunos, incluídos no ensino superior por meio dessas políticas de inclusão, não tinham condições de assumir integralmente o valor das mensalidades cobradas pelas instituições de ensino superior privadas, pois tinham de fato uma renda familiar baixa.

Com o crescimento da inadimplência, as pesquisas da ACSP constataram que o desemprego era a principal causa da inadimplência, o que não era de estranhar, haja vista que o país vinha de uma das maiores crises de sua história. Por essa razão, o governo tomou uma medida econômica drástica para poder colocar o trem nos trilhos, ou melhor, o país nos eixos: um novo plano econômico, o PLANO REAL, foi 
implantado, visando sobretudo controlar a inflação e retomar o crescimento econômico, para diminuir o desemprego e a miséria que assolava o país.

É inegável que o Plano Real contribuiu imensamente para a estabilização da economia, porém, o desemprego permanecia, pois a economia ainda não havia reagido por completo e os alunos que adentravam o ensino superior e suas famílias ainda sofriam os reflexos dessa situação, que, por certo, era extremamente complexa. A economia estava fraca e o desemprego estava em alta, os juros estavam nas nuvens e o PIB estava baixíssimo. Esses fatores combinados eram os maiores empecilhos para aqueles que queriam estudar em uma instituição de ensino superior privada.

Tabela 2 - Causas da inadimplência educacional

\begin{tabular}{|l|c|}
\hline Desemprego & $54 \%$ \\
\hline Endividamento & $17 \%$ \\
\hline Fiança ou Avalista & $15 \%$ \\
\hline Empréstimo de documentos & $8 \%$ \\
\hline Problemas de saúde e outros & $6 \%$ \\
\hline
\end{tabular}

Fonte: Rodrigues (2004, p. 73).

Por outro lado, as IESP, que tinham uma gestão majoritariamente familiar, viram-se obrigadas a profissionalizar sua gestão, em razão tanto do aumento do número de alunos quanto do aumento da inadimplência, de funcionários, além do aumento da concorrência, passando assim por uma grande transformação no que diz respeito à sua gestão administrativa e financeira.

Em função desses problemas, as IESP viram como solução para a inadimplência a terceirização da cobrança. Por conta disso, as IESP começaram a encaminhar os débitos de mensalidades vencidas para os escritórios especializados na área de cobrança educacional. Escritórios como a CAMARGO RODRIGUES. 
$\mathrm{Na}$ realidade, entende-se que, em parte, as IESP acabaram terceirizando a cobrança porque não dominavam completamente o processo de cobrança extrajudicial. Ademais, essas instituições não tinham nem a expertise nem a mão de obra com knowhow para fazer a cobrança extrajudicial internamente. Tampouco tinham conhecimento da legislação específica aplicável ao assunto, e não conheciam profundamente os processos administrativos; em suma, desconheciam completamente a cobrança extrajudicial, sendo, portanto, pouquíssimo eficiente nesse quesito.

Por outro lado, como se verá a seguir, as IESP não tinham também a expertise e o conhecimento necessários para realizar a cobrança judicial de tais débitos, haja vista que, para a realização da cobrança judicial, é necessária a contratação de mão de obra especializada, como advogados e assistentes jurídicos. Além disso, estes profissionais deveriam ter conhecimentos específicos de Direito Educacional, que são adquiridos fora da Universidade, pois grande parte da matéria encontra-se legislada por via de legislação esparsa, indo além da Constituição e do Código Civil.

Assim, a estabilização da economia ocorrida a partir do Plano Real deu início à expansão do ensino superior privado, gerando a inclusão de milhões de alunos na Universidade. Contudo, essa expansão gerou um desequilíbrio econômico financeiro grande nas IESP, pois, basicamente, ela ocorreu de forma desorganizada e de cima para baixo, incluindo no sistema educacional estudantes das classes $\mathrm{C}$ e $\mathrm{D}$, que não tinham condições financeiras de assumir o pagamento das mensalidades das Universidades privadas. Naquele momento não havia ainda nenhum tipo de financiamento público ou privado, que seria uma alternativa para os alunos de baixa renda.

Segundo Moritz et al. (2011), as formas de financiamento surgiram em nosso país somente depois de 2005, possibilitando que os alunos de baixa renda tivessem acesso ao ensino superior através de bolsas integrais ou financiamentos. gratuitamente é o Pro Uni (Programa Universidade para Todos), desenvolvido pelo governo federal com o intuito de cumprir as metas do PNE - Plano Nacional de Educação. Criado em 2004, pela Lei no 11.096/2005. O Pro Uni, tem como finalidade a concessão de bolsas de estudos parciais e integrais para cursos de graduação, sequenciais e de formação específica, em instituições de 
ensino superior privadas, sendo que as instituições de ensino superior que aderem ao programa recebem isenção de tributos.

Outro grande aliado dos alunos que não têm condições de arcar com o valor integral das mensalidades do ensino superior é o FIES - Fundo de Financiamento ao Estudante do Ensino Superior, que é um programa do Ministério da Educação destinado a financiar prioritariamente estudantes de cursos de graduação. Podem recorrer ao financiamento os estudantes matriculados em cursos superiores presencias que tenham avaliação positiva nos processos conduzidos pelo Ministério da Educação.

Contudo, até que isso ocorresse, os alunos do ensino superior ficavam inadimplentes quando matriculados em instituições privadas, obrigando as instituições a realizarem, a partir da estabilização da economia, a cobrança desses débitos.

Nesse momento, algumas instituições iniciaram um processo de profissionalização da cobrança. Parte delas terceirizou esse serviço, mediante a contratação de empresas de cobrança, enquanto outras iniciaram o processo de cobrança interna.

A CAMARGO RODRIGUES ofereceu ao mercado a possibilidade de profissionalizar a cobrança amigável através da terceirização dos serviços - pois os custos eram menores do que a realização da cobrança interna e eram remunerados "ad êxito", ou seja, sobre o valor efetivamente recuperado -, transformando um custo fixo de um departamento interno de cobrança em variável de uma empresa contratada para esse fim. 


\section{2- COBRANÇA AMIGÁVEL}

A oportunidade de realizar a cobrança amigável de mensalidades atrasadas para as instituições de ensino privadas surgiu logo após a estabilização da economia, pois a partir desse momento o Brasil iniciava uma nova fase econômica, com a inflação sob controle e com uma nova moeda, algo extremamente importante sob o ponto de vista econômico.

Com a estabilização da economia, sem inflação e com moeda forte, os números da inadimplência começaram a se tornar preocupantes nos balanços das IESP. Nos anos 90, muitas instituições não tinham fins lucrativos, pois eram Institutos ou Fundações de Ensino, e não empresas privadas, de responsabilidade limitada e sofriam alta fiscalização dos órgãos de controle, como o Tribunal de Contas do Município.

Em razão disso, a inadimplência era tratada por essas Fundações de forma mais social e menos profissional, ou seja, o aluno devedor praticamente não era cobrado até o período de rematrícula e, por conta disso, inexistindo a dor, inexistiam empresas especializadas na cobrança educacional.

No caso da CAMARGO RODRIGUES, a oportunidade de realizar a cobrança de inadimplentes para o setor educacional surgiu, de fato, quando o autor deste projeto foi contratado, em 1994, pelas Faculdades Oswaldo Cruz para prestar serviços no andamento de projetos de abertura de novos cursos perante o MEC em Brasília. Dois anos depois, a inadimplência explodiu, atingindo níveis alarmantes para a instituição. Foi quando o Diretor geral me chamou e me perguntou se eu não queria montar um escritório para fazer a cobrança dos inadimplentes das faculdades e das escolas do grupo.

Assim, em 1996, constituímos a CAMARGO RODRIGUES, que foi pioneira no setor educacional, pois naquele momento ainda não existiam empresas de cobrança que realizassem exclusivamente a cobrança educacional. Até hoje, desconhecem-se empresas que trabalhem exclusivamente para o setor educacional. De forma geral, as empresas de cobrança trabalham para bancos, comércio, indústria e cartões de crédito. 
Inicialmente, a empresa tinha seis funcionários: uma faxineira, uma recepcionista, dois atendentes, um auxiliar administrativo financeiro e o autor desta dissertação. Ela foi estabelecida na Avenida Paulista, em São Paulo, Capital, endereço que nenhum devedor poderia alegar desconhecer, uma vez que a Avenida Paulista é a avenida mais famosa do Brasil.

No início, os departamentos de TI, de marketing e de contabilidade eram todos terceirizados para profissionais do ramo e remunerados por projeto, exceto a contabilidade, que tinha um custo mensal fixo. Desde o início houve grande preocupação com custos fixos, visando não onerar em demasia a empresa. Nesse sentido, o pró-labore inicial dos sócios era de apenas 5 salários mínimos.

O crescimento da empresa nos 5 primeiros anos foi impressionante, chegando a mais de 10 vezes: no ano de 1996, que foi o primeiro ano, o faturamento bruto foi de $\mathrm{R} \$$ 175 mil reais, em 2001 ficou em $\mathrm{R} \$ 1.816 .897,00$.

Tabela 3 - Crescimento nos 5 primeiros anos

\begin{tabular}{|c|c|c|c|c|}
\hline ANO & RECEITA & CRESCIMENTO & FUNCIONÁRIOS & ACORDOS \\
\hline $\mathbf{1 9 9 6}$ & $175.317,00$ & 0 & 5 & 1.009 \\
\hline $\mathbf{1 9 9 7}$ & $372.692,00$ & $112,58 \%$ & 6 & 1.544 \\
\hline $\mathbf{1 9 9 8}$ & $515.081,00$ & $38,20 \%$ & 7 & 2.076 \\
\hline $\mathbf{1 9 9 9}$ & $605.244,00$ & $17,50 \%$ & 7 & 2.272 \\
\hline $\mathbf{2 0 0 0}$ & $1.064 .222,00$ & $75,83 \%$ & 12 & 5.062 \\
\hline $\mathbf{2 0 0 1}$ & $1.816 .897,00$ & $70,72 \%$ & 18 & 10.687 \\
\hline
\end{tabular}


A empresa iniciou suas atividades em decorrência de uma oportunidade do mercado educacional, que passou por várias transformações após a estabilização da economia com o advento do Plano Real em 1994.

Uma vez definido o segmento de clientes, inicialmente a empresa se dispôs a resolver o problema da inadimplência educacional das instituições de ensino privadas localizadas na cidade de São Paulo Capital.

O serviço de cobrança amigável era feito mediante um modelo de cobrança próprio e com um software próprio.

Esse modelo foi amplamente divulgado através de livros e palestras. O modelo defendia que as mensalidades vencidas fossem mensalmente enviadas pelas IESP para a CAMARGO RODRIGUES, que imediatamente iniciava o processo de cobrança por meio de cartas e telefone, visando realizar com o aluno-devedor um acordo extrajudicial de forma amigável. Uma vez realizados os acordos com os alunos devedores, os valores efetivamente recebidos eram mensalmente transferidos para as IESP mediante a prestação de contas.

O modelo de cobrança desenvolvido pela CAMARGO RODRIGUES propunha a cobrança em 4 fases:

1- Matrícula e assinatura do contrato de prestação de serviços educacionais;

2- $\quad$ Cobrança interna, realizada pela IESP;

3- Cobrança amigável, realizada pela CAMARGO RODRIGUES;

4- Cobrança judicial, realizada pela RAF ADVOGADOS.

Através desse modelo de cobranças conseguiu-se recuperar até $1200 \%$ dos débitos em aberto que as IESP tinham, pois identificou-se que existiam devedores para cada uma delas, ou seja, existiam devedores que pagavam assim que a IESP cobrasse; havia aqueles que só pagavam quando cobrados por um agente externo e, além desses, existiam devedores que só pagavam em juízo.

Portanto, conclui-se que, para obter um resultado ótimo, a IESP deveria realizar a cobrança interna, depois a cobrança externa através de uma cobrança amigável e, finalmente, a cobrança judicial. Contudo, para que tudo isso fosse possível, seria 
necessário que a primeira fase tivesse sido realizada corretamente, colhendo a assinatura do aluno no contrato de prestação de serviços assim que ele se matriculasse, pois, para que a cobrança amigável e, principalmente, a judicial fossem possíveis, era imprescindível que a IESP comprovasse três coisas fundamentais: 1) que o aluno havia contratado o serviço (assinatura do contrato de prestação de serviços educacionais); 2) que ele havia usufruído do serviço (lista de presença, boletim de notas); 3) que ele não havia pago o serviço (ficha financeira).

\section{3- A ESTRATÉGIA}

Estrategicamente, a CAMARGO RODRIGUES optou por atuar exclusivamente na cobrança educacional de mensalidades atrasadas de alunos que estudavam em instituições de ensino fundamental, médio e superior privadas.

Tal estratégia aplicava a teoria de diferenciação como vantagem competitiva (PORTER, 1989) em relação ao setor de cobrança tradicional, que também prestava serviço para outros setores da economia. Com isso, a empresa visava, portanto, diferenciar-se das empresas já existentes, tornando-se única na indústria de cobrança que já vinha prestando serviços de cobrança extrajudicial há muitos anos para bancos e empresas de cartão de crédito.

Porter (2004, 1989, p. 9-10) observou a importância de focar a estratégia da empresa em diferenciação ou em custo:

A base fundamental do desempenho acima da média em longo prazo é a vantagem competitiva sustentável. Embora uma empresa possa ter inúmeros pontos fortes e pontos fracos em comparação com seus concorrentes, existem dois tipos básicos de vantagem competitiva que uma empresa pode possuir: baixo custo ou diferenciação. A importância de qualquer ponto forte ou ponto fraco que uma empresa possui é, em última instância, uma função de seu impacto sobre o custo relativo ou a diferenciação. A vantagem de custo e a diferenciação, por sua vez, originam-se da estrutura industrial. Elas resultam da 
habilidade de uma empresa em lidar com as cinco forças melhor do que seus rivais.

Os dois tipos básicos de vantagem competitiva combinados com o escopo de atividades para as quais uma empresa procura obtê-los levam a três estratégias genéricas para alcançar o desempenho acima da média em uma indústria: liderança de custo, diferenciação e enfoque. A estratégia do enfoque tem duas variantes: enfoque no custo e enfoque na diferenciação.

Também nesse sentido, Mintzberg (2010, p. 105) aborda o posicionamento, citando o modelo de Porter de análise competitiva e classificando-o como a terceira onda da escola de posicionamento, que se iniciou na década de 70 e atingiu seu auge na década de 80 do século passado. Lá, Mintzberg deixa claro que Porter evidenciou a importância da análise do ambiente externo e das estratégias internas, falando tanto das 5 forças de Porter, como das "Estratégias Genéricas". Estas foram aplicadas pela CAMARGO RODRIGUES tanto no início da empresa como atualmente, na decisão de desenvolvimento do novo serviço ora apresentado, visando com isso possibilitar a retomada do crescimento da empresa, tendo em vista a entrada de "novos entrantes", além de outros fatores já mencionados que causaram o declínio da empresa, como concentração do setor, financiamento federal e tecnologia.

$\mathrm{Na}$ sequência de seu relato, Mintzberg (2010) também ressalta que Porter afirmou que existem dois tipos básicos de vantagem competitiva: baixo custo e diferenciação, estratégias em que a CAMARGO RODRIGUES se baseou para definir sua atividade principal e realizar o desenvolvimento deste novo serviço (Compra de recebíveis Vencidos), buscando assim criar barreiras aos "novos entrantes" mencionados por Porter.

Mintzberg (2010, p. 110), para quem "a partir de Porter, a literatura de posicionamento estratégico floresceu", conclui dizendo:

A escola de posicionamento originalmente via a formulação de estratégia como um processo que consiste em encontrar a posição que pode suportar melhor a competição existente e potencial. Mas focar a concorrência restringe a visão e reduz a criatividade estratégica. Isso também pode ser contra produtivo: um avanço competitivo agressivo tende a provocar outro, em um ciclo maior que não deixa ninguém em melhor posição. 


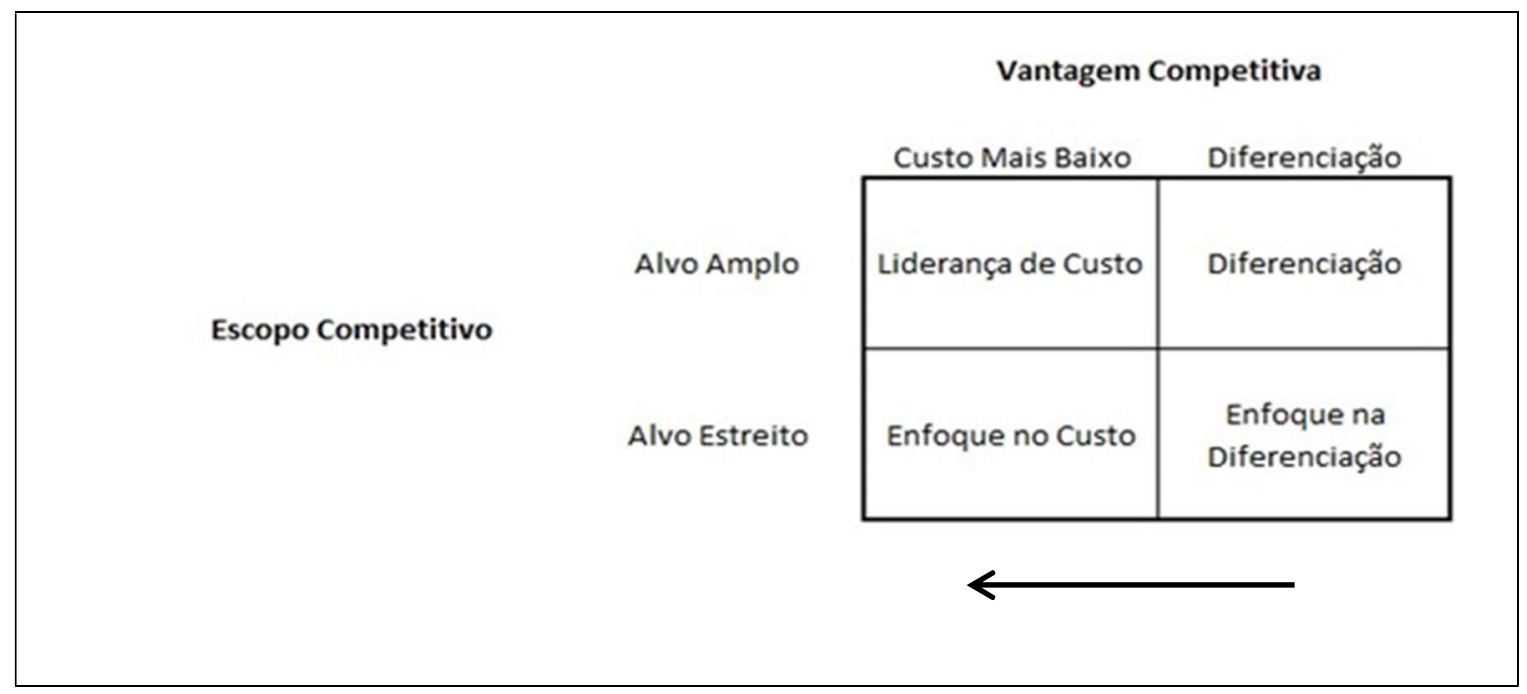

Figura 3 - Três Estratégias Genéricas

Fonte: Porter (1989, p. 10).

Entretanto, com o passar dos anos, a estratégia foi se deslocando dentro do alvo estreito, partindo do "enfoque em diferenciação" para o "enfoque em custos", mas isso demorou alguns anos, pois, apesar de a empresa não ganhar novos clientes, ela tinha muitos clientes fiéis e ainda era muito reconhecida como a melhor empresa do mercado.

Além disso, ela tinha alguns diferenciais, como ser extremamente eficiente no que fazia e transparente. Doravante, a empresa seria a mais cara do mercado e famosa por sua localização privilegiada - “aquela que fica na Paulista, né?”.

Tendo em vista essa admiração, a empresa manteve-se firme na estratégia de "enfoque na diferenciação", sem notar que o mercado estava baixando seus preços.

Assim, depois de 2008, ela começou a pagar um preço alto por isso, deixando de conquistar novos clientes pois o mercado havia ficado mais sensível aos preços, dando preferência a contratar as empresas que tinham preços mais baixos, ainda que estas empresas não fossem tão eficientes quanto a CAMARGO RODRIGUES e não entregassem o mesmo serviço. Mas o mercado, nesse momento, queria preço e um bom serviço.

Como se verá, uma alternativa foi criar um serviço com maior valor agregado que no caso em tela: a cobrança judicial, através da RAF ADVOGADOS, que foi muito 
bem recebida pelos clientes, gerando uma receita significativa que compensou as perdas geradas pelo declínio da cobrança amigável.

\section{4- O DECLÍNIO DA COBRANÇA AMIGÁVEL}

Entre 1996 e 2008 a empresa voou em céu de brigadeiro, em verdadeiro Oceano Azul, pois não tinha concorrentes que atuavam exclusivamente para o segmento educacional. Esse foi um grande diferencial no início da empresa.

Kim (2005, p. 47) disse em seu livro que, estrategicamente, devem-se sempre buscar oportunidades de oceano azul:

\footnotetext{
O primeiro princípio da estratégia do oceano azul é reconstruir as fronteiras do mercado para se libertar da concorrência e criar oceanos azuis. Esse princípio trata dos riscos da busca com o qual se defrontam muitas empresas. O desafio é identificar com sucesso, em meio à pilha de possibilidades existentes, oportunidades de oceano azul comercialmente atraentes. Este desafio é fundamental, pois os gestores não podem se dar ao luxo de atuarem como jogadores em um cassino, os quais apostam na estratégia apenas com base na intuição ou em palpites.
}

Durante esse período inicial, a empresa foi muito interessante comercialmente, realizando um grande trabalho de cobrança para as IESP. Contudo, a fase de oceano azul perdurou apenas até o ano de 2009; a partir desse momento, a empresa começou a sofrer um processo de queda no faturamento. Tal fato ocorreu por diversos fatores, como se verá mais detalhadamente à frente, a maioria deles externos, ou seja, alheios ao ambiente da empresa e, por conta disso, fora de seu controle. Eram ameaças previsíveis que se concretizaram ao longo dos anos, deixando a empresa em uma situação extremamente delicada, o que a obrigou a se reestruturar totalmente, fechar unidades e dispensar colaboradores. 
Além disso, como se disse anteriormente, a empresa teve também que alterar sua estratégia, migrando então para o quadrante de liderança em custos com enfoque em custos. Entretanto, esta estratégia demorou anos para dar resultado, pois a empresa já tinha desenvolvido a imagem perante seus clientes de uma empresa com qualidade, porém "careira", ou seja, que cobrava caro pelo que fazia.

Alguns anos se passaram até que a empresa retomasse o crescimento. Muitos cortes tiveram que ser feitos, unidades foram fechadas, e somente em 2012 a empresa voltou a crescer, como se pode ver na figura abaixo (Figura 4), e muito lentamente. Na realidade, ela conseguiu simplesmente interromper a trajetória de queda que vinha ocorrendo.

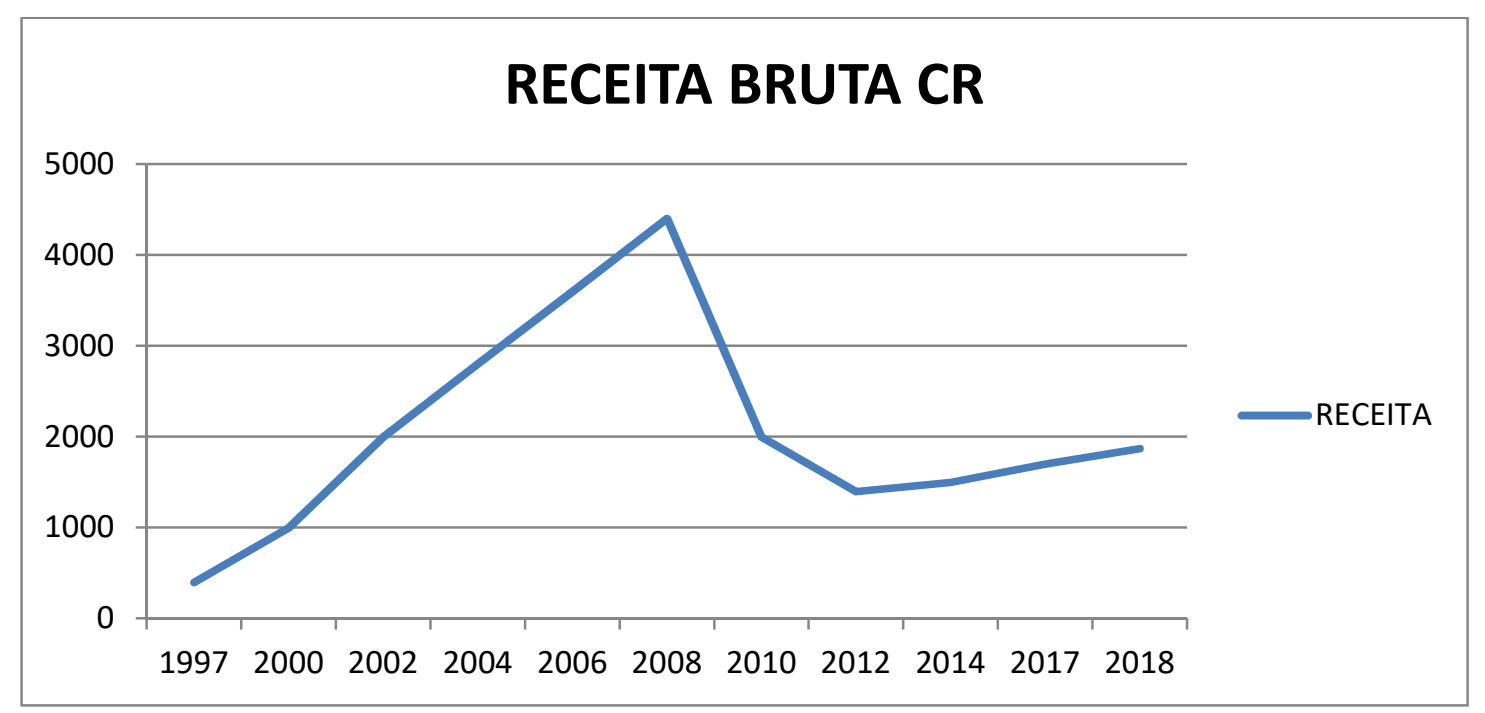

Figura 4 - Receita Bruta CAMARGO RODRIGUES de 1997 a 2018

Fonte: O autor. Relatórios de fechamento anual.

Outro fator que pode ter contribuído para o declínio da empresa foram os avanços tecnológicos. Acredita-se que a tecnologia interferiu negativamente no crescimento da empresa, agravando ainda mais profundamente o cenário, pois com o desenvolvimento tecnológico, muitas IESP passaram a realizar a cobrança por conta própria, ou seja, internamente. Tal fato ocorreu quando as IESP passaram a implantar sistemas de gestão educacional (ERP). Esses sistemas passaram a oferecer um módulo de cobrança, pois as empresas de software identificaram que esta era uma "dor" do 
cliente e que elas poderiam estruturar o processo de cobrança interno, o que levou as IESP a encerrar os contratos de prestação de serviços com as cobradoras, pois assim cortariam custos e teriam autonomia no processo de cobrança de inadimplentes.

Para agravar ainda mais a situação, nessa mesma época os meios de financiamento e os programas de bolsa como FIES e PROUNI, respectivamente, começaram a impactar negativamente a empresa, pois a inadimplência estava muita alta e as IESP passaram a pressionar o governo para que aumentasse o volume dos financiamentos e bolsas.

Como alternativa a essas ações que vinham prejudicando o desempenho da CAMARGO RODRIGUES, esta optou por criar um novo serviço. Sendo assim, partiu para realizar algo que fosse mais especializado e com maior valor agregado - a Cobrança Judicial. Assim, constituiu-se a RODRIGUES, ABUD E FERRERONI ADVOGADOS - RAF ADVOGADOS.

Com este novo serviço a empresa, como um todo, visava viver a segunda onda de crescimento, oferecendo ao cliente um novo serviço, mais especializado e de maior responsabilidade, ainda pouco executado pelos concorrentes, pois era muito mais complexo do que a cobrança amigável extrajudicial e exigia conhecimento específico da legislação educacional, aplicável aos casos.

Segundo Schwab (2016), o mundo está em rápida transformação e precisamos agir transformando desafios em oportunidades:

Claramente, os desafios são tão assustadores como as oportunidades são convincentes. Juntos, devemos trabalhar para transformar esses desafios em oportunidades, ao nos prepararmos de forma adequada - e proativa - para seus efeitos e impactos. $\mathrm{O}$ mundo está em rápida mudança, hiperconectado, cada vez mais complexo e mais fragmentado, mas nós ainda podemos moldar o nosso futuro de uma forma que beneficie a todos. A janela de oportunidade para fazer isso é agora.

E para poder aproveitar essas novas oportunidades, era necessário inovar, fazendo algo novo. Algo que fosse inédito. Segundo Osterwalder (2011), para uma 
empresa encontrar os caminhos para a inovação e para a renovação seria interessante combinar a análise SWOT com o Canvas de Modelo de Negócios, pois isso possibilitaria uma análise mais focada. É o que se vê na seguinte citação (OSTERWALDER, 2011, p. 216):

Analisar a consistência do seu Modelo de Negócios é crucial, mas observar seus componentes em detalhes também pode revelar interessantes caminhos para inovação e renovação. Uma maneira eficiente de se fazer isso é combinando a clássica análise de forças, fraquezas, oportunidades e ameaças (SWOT- sigla em inglês) com o Canvas de Modelo de Negócios. A análise SWOT fornece o foco necessário para uma discussão estruturada.

A análise SWOT faz quatro perguntas simples mas amplas. As duas primeiras - quais são as maiores forças e fraquezas de sua empresa? - analisam sua organização internamente. As duas seguintes - quais oportunidades sua organização tem, e quais ameaças ela enfrenta? - analisam a posição de sua organização dentro do ambiente.

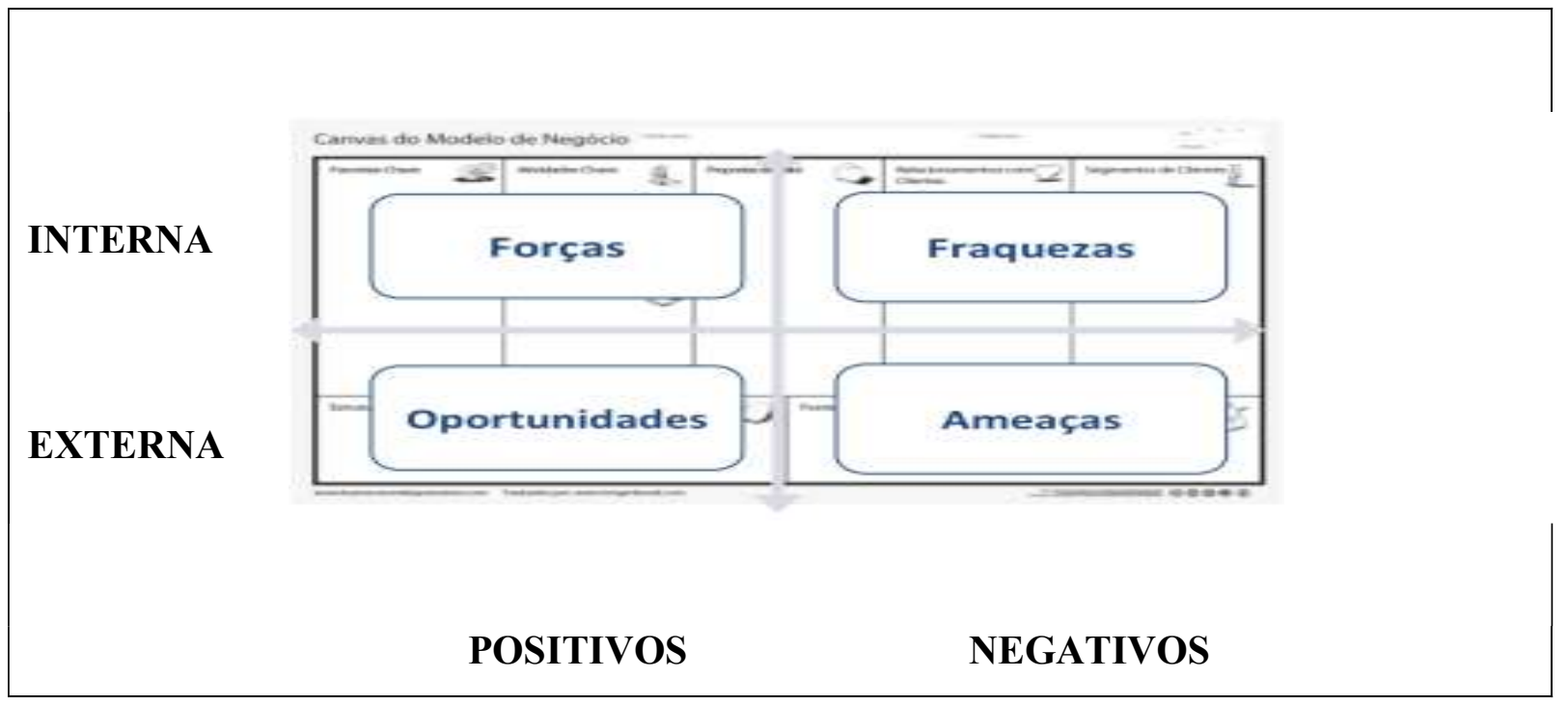

Figura 5 - SWOT. Com Canvas

Fonte: Internet, Google, SWOT+CANVAS, Imagens.

$<$ https://www.google.com.br/search? $\mathrm{q}=$ swot $+\% 2 \mathrm{~B}+$ canvas\&source $=$ lnms\&tbm $=\mathrm{isch} \& \mathrm{sa}=\mathrm{X} \& \mathrm{ved}=0 \mathrm{ahU}$ KEwjpofnz4veAhVEPJAKHYXPBk8Q_AUIDigB\&biw=1137\&bih=559\#imgrc $=$ mCWrtefXYNi1nM:\&s $\mathrm{pf}=1539715651226>$. 
Nesse sentido ainda, Collins (1995, p. 215) diz que as empresas visionárias são como as espécies descritas por Charles Darwin, elas evoluem na medida em que conseguem se adaptar às mudanças ocorridas no ambiente de negócios, e muitas vezes após um fracasso ou após cometer um erro estrondoso. Ele chama isso de "processo evolutivo":

Nós costumamos descrever o processo evolutivo como "processo de ramificação e poda". A ideia é simples: se você acrescentar uma quantidade suficiente de galhos a uma árvore (variação) e podar com inteligência a madeira morta (seleção), você provavelmente evoluirá, transformando a árvore num conjunto de galhos saudáveis e bem posicionados para prosperar num ambiente em constante transformação.

O autor (COLLINS, 1995, p. 217) ainda ressalta que muitas empresas evoluem graças ao fato de aproveitarem as oportunidades que deram certo e por corrigirem ou descartarem aquelas que não deram certo, ou seja, o que nem sempre ocorre em função de um grande planejamento estratégico:

Pode ser muito mais satisfatório imaginar não que as empresas visionárias mais aptas sejam resultado de uma percepção brilhante e do planejamento estratégico, mas que sejam consequências de um processo básico - ou seja, fazer várias experiências, agarrar as oportunidades, ficar com as que dão certo (coerentes com a ideologia central) e corrigir ou descartar as que não dão certo.

A cobrança judicial era algo que a empresa já vinha fazendo há muitos anos, contudo sem divulgar muito para os clientes, pois ainda naquele momento os custos para ajuizar uma ação judicial de cobrança eram muito altos e os resultados eram baixos, em razão de os processos serem extremamente morosos.

Contudo, mesmo assim, a partir de 2009, tendo em vista a queda de receita da $\mathrm{CR}$, acreditou-se que poderia ser uma oportunidade de prestar um serviço com maior valor agregado, pois este serviço tinha sinergia com a cobrança amigável. 
Naturalmente, a cobrança judicial era o próximo passo, principalmente para as ações cujo valor fosse justificável na relação custo/benefício.

\section{5- COBRANÇA JUDICIAL}

Em 2009, foi criada a RODRIGUES ABUD FERRERONI ADVOGADOS RAF ADVOGADOS, escritório de advocacia voltado exclusivamente para a cobrança judicial dos débitos educacionais que não haviam sido negociados extrajudicialmente pela CAMARGO RODRIGUES.

De certa forma, realizar a cobrança judicial foi uma evolução natural da cobrança amigável, pois era uma atividade que tinha sinergia com o que se fazia no campo extrajudicial. Nesse momento, iniciou-se um novo ciclo de crescimento, que se manteve crescente até o ano de 2016.

A cobrança judicial foi a solução encontrada, na época, para compensar a queda da receita da CAMARGO RODRIGUES. O novo serviço de cobrança judicial mostrouse bastante interessante no início, sendo, em grande parte, contratado pelos principais clientes da CAMARGO RODRIGUES. Depois, surgiram novos clientes também. Estes clientes valorizaram a expertise acumulada pela equipe na cobrança extrajudicial, bem como o profundo conhecimento da legislação educacional que a empresa detinha.

A receita bruta anual deste novo serviço chegou a $\mathrm{R} \$ 2.246 .000,00$ em 2016, o que representava 5 vezes o faturamento inicial da empresa. Contudo, em meados de 2017 o escritório começou a apresentar sinais de que o modelo já estava sendo copiado pela concorrência e um novo ciclo de queda se iniciou, então, pelos mesmos fatores que acometeram a cobrança amigável, o principal deles a concorrência.

Como se pode observar a seguir, a receita bruta de 2009 a 2017 cresceu até 2016, quando então os efeitos da concorrência começaram novamente a se confirmar, interrompendo o ritmo de crescimento do escritório de advocacia que realizava a cobrança judicial das mensalidades vencidas dos alunos de instituições de ensino superior privadas. 


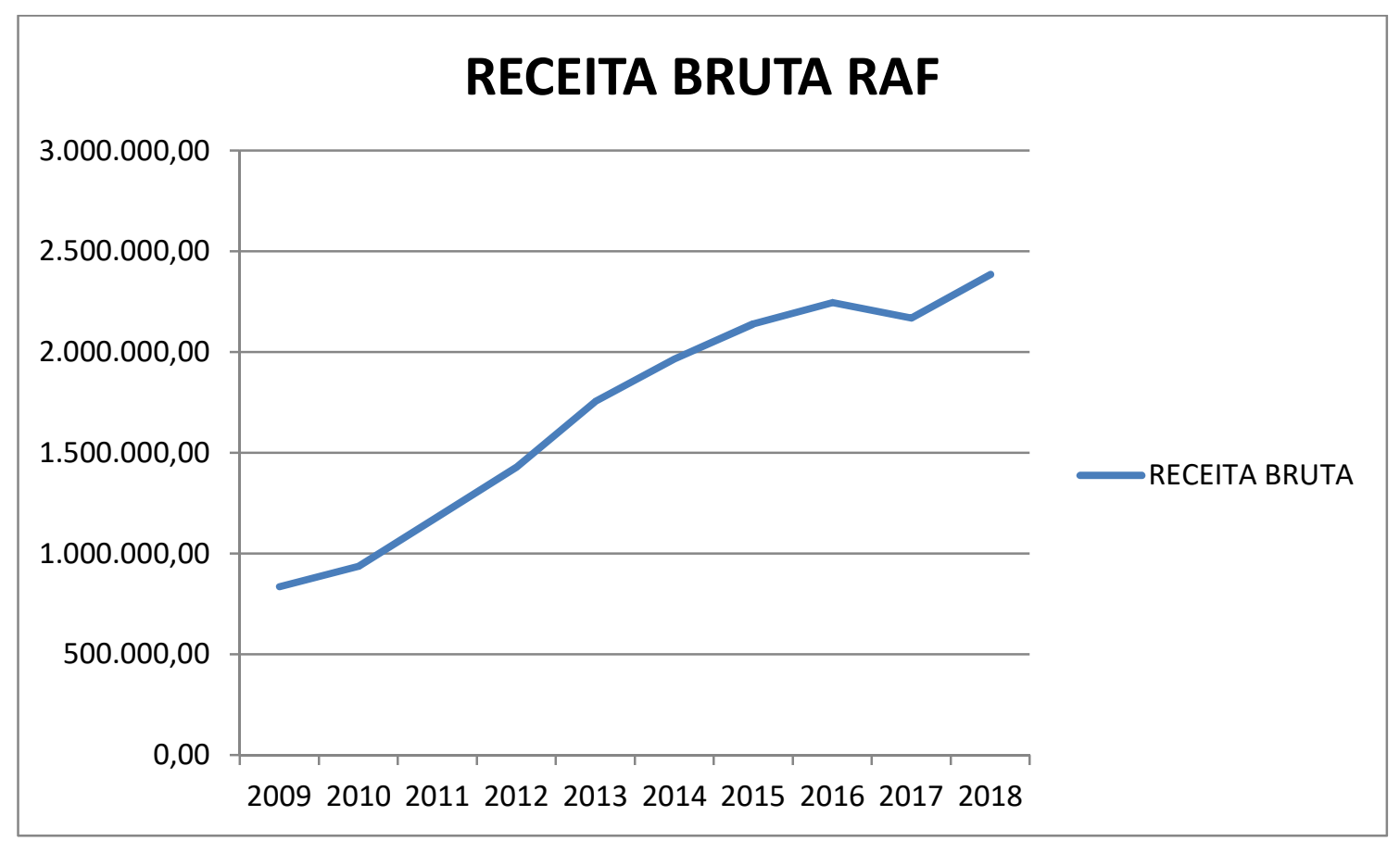

Figura 6 - Receita Bruta RAF de 2009 a 2018

Fonte: O autor. Relatórios financeiros de fechamento anual.

Tal fato gerou a necessidade de novamente fazer uma análise do que estava acontecendo, pois novamente a empresa verificava a ocorrência de um movimento semelhante ao da receita da cobrança amigável e agora em um tempo menor, pois em apenas 8 anos a receita da RAF ADVOGADOS se estabilizou e começou a cair.

Com isso, mais uma vez buscou-se identificar as causas do declínio do grupo de cobrança amigável e da cobrança judicial de uma forma geral, a fim de pontuar o que estava ocorrendo e gerando o declínio e a queda de receita das empresas.

Ao estudar o assunto, identificando alguns fatores que poderiam estar causando a queda do crescimento, consequentemente poderiam ser definidas ações que possibilitassem a retomada do crescimento do grupo como um todo. E esta era, naquele momento, uma grande dúvida: como retomar o crescimento do grupo de cobrança educacional?

Dessa forma, a seguir, analisar-se-á detalhadamente o declínio da cobrança educacional de forma geral, visando entender o processo de declínio pelo qual o grupo 
passou como um todo, para então buscar respostas tanto para as causas do problema, como para abrir caminhos para solucionar o mesmo de tal forma que o grupo volte a crescer.

De fato, a estabilização da receita da cobrança judicial foi mais um alerta importante para que se buscassem respostas para o que estava ocorrendo, evitando-se assim um mal maior, que poderia ser a falência do grupo. 


\section{6- O CICLO DE VIDA DAS EMPRESAS}

Analisando a teoria das empresas e o declínio do grupo como um todo, identificou-se que o declínio vivido pela CAMARGO RODRIGUES ocorre na vida de toda e qualquer empresa, pois as empresas têm uma natureza dinâmica e apresentam determinados padrões em seu crescimento e em seu desenvolvimento. Esses padrões são percebidos ao se analisar o ciclo de vida das organizações (ADIZES, 1993).

Na realidade, o Prof. Adizes (1993, Introdução, p. XVII) nos diz que "as organizações são organismos vivos que apresentam padrões de comportamento em seu crescimento e desenvolvimento". Segundo ele, "o sucesso ou o fracasso de uma organização depende de como ela irá enfrentar os problemas que surgem em cada uma das etapas de seu crescimento". Para ele, é comum que uma empresa que tem, no início, uma boa margem de lucros, veja que esta diminui quando começa a ser imitada pela concorrência, o que faz com que o faturamento diminua e a margem líquida caia também, e foi exatamente isso o que ocorreu com a CAMARGO RODRIGUES, como se viu nos gráficos anteriores.

Segundo Adizes (1993, p. 2 da introdução à parte I do livro), as empresas envelhecem porque elas perdem flexibilidade e controlabilidade:

\footnotetext{
Assim como ocorre com os organismos vivos, o crescimento e o envelhecimento das organizações manifestam-se primordialmente na interrelação entre dois fatores: flexibilidade e controlabilidade. A organizações quando jovens são bastante flexíveis, mas nem sempre são controláveis. $\mathrm{Na}$ medida em que as organizações envelhecem, essa relação se altera. A controlabilidade aumenta e a flexibilidade diminui. É a mesma diferença que há entre um bebê e uma pessoa mais velha. O bebê é bastante flexível e consegue até colocar o pé na boca, mas seus movimentos e o seu comportamento não são muito controláveis. Na medida em que envelhecemos, acabamos eventualmente perdendo também o controle.
}

Para Andrade et al. (2004, p. 9), as pequenas empresas, apesar de terem menos recursos que as grandes empresas, passam por todas as fases do ciclo de vida ao longo 
de sua trajetória, da mesma forma que as grandes empresas, e não poderia ser diferente com a CAMARGO RODRIGUES:

\begin{abstract}
As empresas de uma forma geral buscam se adequar ao tipo de ambiente em que estão inseridas ao longo de toda a sua trajetória de vida. A cada fase da vida empresarial ela vivencia momentos particulares e característicos de cada fase que pode estar distribuída no nascimento, crescimento, no desenvolvimento ou no envelhecimento. Assim, a preocupação de se estudar os diferentes estágios de ciclo de vida das organizações.
\end{abstract}

Por consequência, as empresas podem até morrer, como dizem Gassman, Frankerberger e Cski (2016, p. 6) quando afirmam que o empresário de hoje deve se preparar mentalmente para a morte de sua empresa, pois estamos vivendo em uma era de vantagem competitiva temporária:

Seja paranoico. As consequências para as empresas na corrida pela inovação são drásticas. $\mathrm{O}$ antigo ditado do The Boston Consulting Group sobre a ordenha de suas vacas leiteiras tornou-se cada vez menos relevante hoje. Mesmo que sejam bem-sucedidas no momento, é importante que as empresas testem regularmente seu modelo de negócio. Um pouco de paranoia não faz mal nenhum, e, como disse Steve Jobs, é crucial questionar os pilares do sucesso de hoje e preparar-se mentalmente para a morte de sua empresa, mesmo que ela esteja muito bem agora. Vivemos em uma era de vantagem competitiva temporária: o sucesso só pode ser mantido se suas raízes forem continuamente reexaminadas e nutridas.

Corroborando o tema acima, pode-se dizer que a CAMARGO RODRIGUES teve sua vantagem competitiva temporária. De certa forma, essa vantagem foi de 1996 a 2008, quando iniciou seu declínio.

O professor Adizes vai além, ao afirmar que, quando a empresa atinge a maturidade, o maior problema enfrentado por ela diz respeito à perda do espírito Empreendedor, o que pode gerar reflexos na administração e na prestação de serviços, os quais correm o risco de perder qualidade lentamente com o passar dos anos. 
Continuando, o professor diz que, não raramente, ao atingir a maturidade, a direção da empresa fica aguardando orientações sobre o que fazer diante dos problemas que surgem; isso quando ela consegue identificá-los claramente, pois muitas vezes a empresa não consegue reagir aos fatos externos, passando a concentrar seus esforços na solução de problemas internos. Isso ocorreu com a CAMARGO RODIGUES. A empresa ficou de 2009 a 2015 sem saber muito bem o que fazer, até que o autor do presente estudo procurou o mestrado profissional em busca de respostas, ideias, inovações e repertório.

$\mathrm{Na}$ figura abaixo, observa-se a matriz do ciclo de vida das empresas. Esta é uma figura clássica desenvolvida pelo professor Adizes em 1993 para ilustrar o que ocorre com a empresa ao longo de sua trajetória. Nela, ficam claras as fases pelas quais as empresas passam ao longo do tempo, do crescimento ao declínio, independentemente de seu porte. Ou seja, tal figura retrata a realidade das pequenas, médias e grandes empresas, de qualquer empresa, e retratou a realidade da CAMARGO RODRIGUES e da RAF ADVOGADOS, como foi possível ver nos gráficos de receitas das duas empresas.

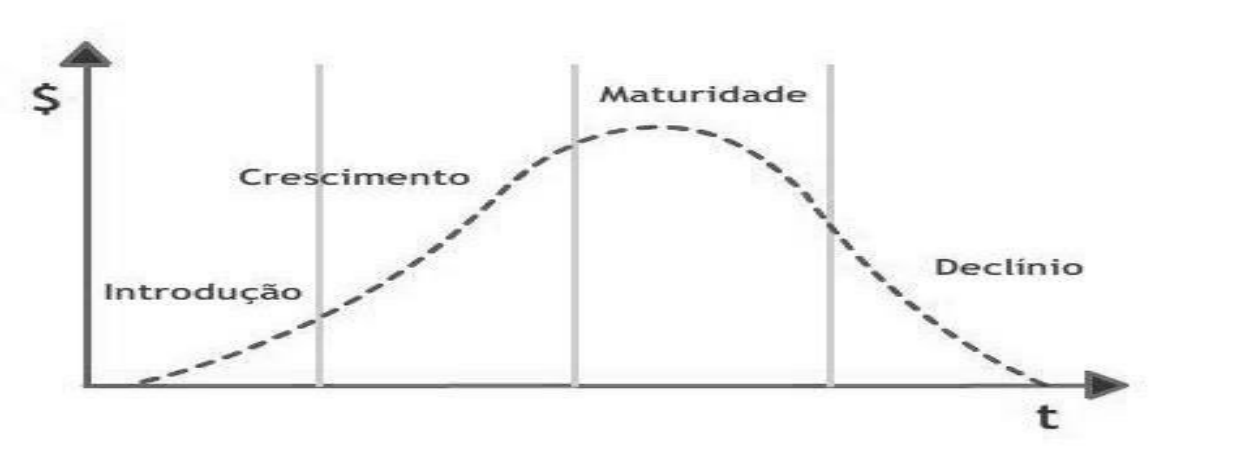

Figura 7 - Matriz ciclo de vida das organizações

Fonte: Internet. Imagens ciclo de vida. Adizes (1993).

Analisando abaixo as fases da empresa de cobrança educacional CAMARGO RODRIGUES, nota-se que a mesma passou inquestionavelmente pelas fases do ciclo de vida das organizações, como tantas outras empresas, quais sejam: introdução, crescimento, maturidade e declínio. 
Tabela 4 - Fases do grupo CAMARGO RODRIGUES

\begin{tabular}{|c|c|c|c|c|}
\hline ANO & $\mathbf{1 9 9 6 - 2 0 0 0}$ & $\mathbf{2 0 0 0 - 2 0 0 4}$ & $\mathbf{2 0 0 4 - 2 0 1 0}$ & $\mathbf{2 0 1 0 - 2 0 1 6}$ \\
\hline FASE & INTRODUÇÃO & CRESCIMENTO & MATURIDADE & DECLÍNIO \\
\hline ESTRATÉGIA & DIFERENCIAÇÃO & DIFERENCIAÇÃO & DIFERENCIAÇÃO & CUSTO \\
\hline ESTRUTURA & 1 UNIDADE & 2 UNIDADES & 4 UNIDADES & 2 UNIDADES \\
\hline FUNCIONÁRIOS & 6 & 20 & 80 & 40 \\
\hline
\end{tabular}

Fonte: O autor.

Esse quadro demonstra de forma clara o movimento da empresa desde sua fundação até os dias de hoje, não deixando margem para dúvidas sobre a realidade da empresa. Por consequência, reconheceu-se que se não fosse feito nada a empresa como um todo poderia morrer, como foi mencionado acima.

Por outro lado, o ciclo de vida do escritório de advocacia RAF ADVOGADOS, que se iniciou em 2009, completou 8 anos, ou seja, atingiu seu auge em 2016. Com isso, notou-se que o ciclo ficou menor, obrigando também o escritório a tomar medidas visando à retomada do crescimento, porém em um espaço de tempo mais curto, haja vista que o ciclo da cobrança amigável foi de 12 anos e o da cobrança amigável foi de 8 anos, conforme se pode verificar na Figura 8.

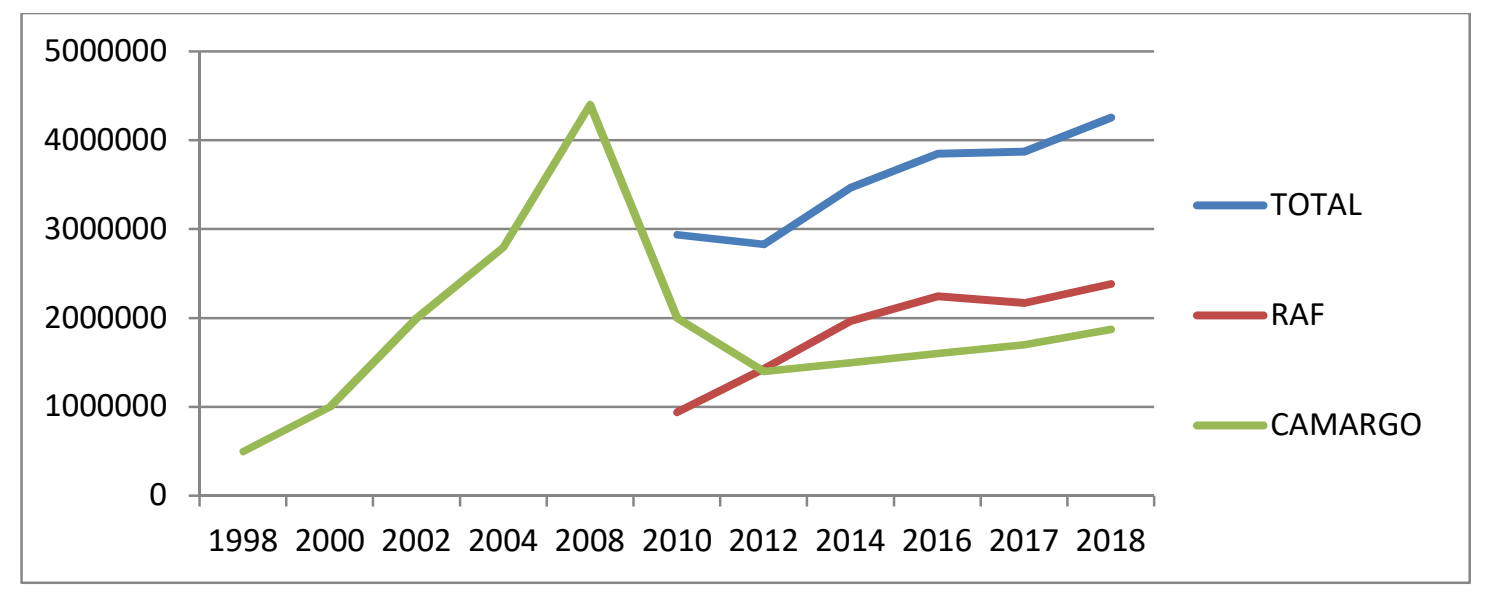

Figura 8 - Receita Bruta CAMARGO, RAF e TOTAL

Fonte: O autor. 
Em função disso, neste estudo fez-se uma análise ainda mais profunda da situação geral da empresa, ao se fazer uma SWOT, ou FOFA, em português, analisando os aspecto internos e o ambiente organizacional, destacando os pontos positivos e negativos, a fim de que tal análise pudesse contribuir na elaboração de um plano de ação que gerasse a retomada do crescimento do grupo.

Esta análise foi importante para identificarmos as semelhanças com os pontos abordados pelos professores citados e buscar soluções para reinventar a empresa CAMARGO RODRIGUES, a fim de evitar que ela viesse a morrer. 
Tabela 5 - Análise SWOT ou FOFA

\begin{tabular}{|c|c|c|}
\hline FATORES POSITIVOS & FATORES NEGATIVOS & \\
\hline $\begin{array}{l}\text { PONTOS FORTES } \\
\text { - Liderança } \\
\text { - Know-how } \\
\text { - Acordo On-line } \\
\text { - Caixa }\end{array}$ & 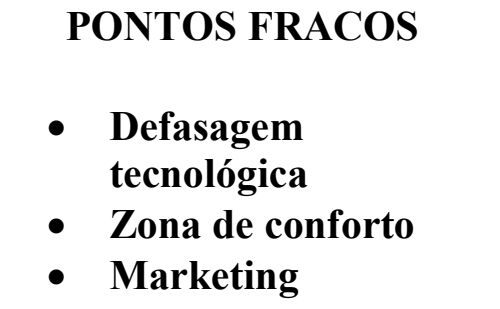 & $\begin{array}{l}\text { ASPECTOS } \\
\text { INTERNOS }\end{array}$ \\
\hline 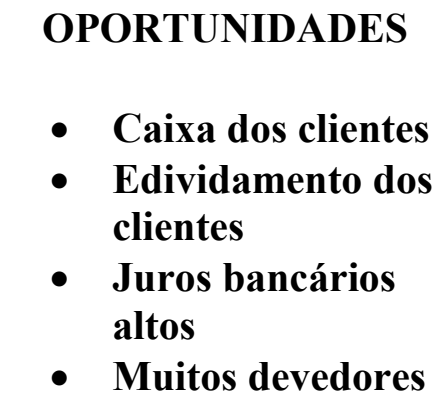 & $\begin{array}{ll} & \text { AMEAÇAS } \\
\text { - } & \text { Concorrência } \\
\text { - } & \text { Concentração do } \\
& \text { setor } \\
\text { - } & \text { PROUNI - FIES } \\
\text { - } & \text { Avanços tecnológicos }\end{array}$ & $\begin{array}{c}\text { AMBIENTE } \\
\text { ORGANIZACIONAL } \\
\text { EXTERNO }\end{array}$ \\
\hline
\end{tabular}

Fonte: O autor.

Analisando o quadro acima, verifica-se que tanto no aspecto interno como no ambiente organizacional externo a empresa apresentou fatores positivos e negativos significativos que merecem destaque, principalmente no que tange aos fatores negativos. Desses, destacam-se, no ambiente interno, o fato de a empresa estar defasada tecnologicamente, estacionada em zona de conforto e também contando com fraca equipe de vendas.

Ademais, destaca-se também que, dentre os pontos negativos, existem os fatores externos, que, como se viu, também contribuíram para a queda do grupo. Desses, 
destacam-se a entrada de concorrentes com preço baixo, a tecnologia oferecendo módulo de cobrança em seus softwares educacionais e, sobretudo o Fies, que ofertou através da CEF bolsas de estudos para os alunos de baixa renda que eram os clientes das IESP atendidas pela CAMARGO RODRIGUES e pela RAF ADVOGADOS.

\section{2- ASPECTOS INTERNOS}

Alguns aspectos internos contribuíram para o declínio das empresas, dentre os quais citam-se aqueles que foram identificados em reuniões internas da empresa como sendo os pontos fracos da empresa:

1- Defasagem tecnológica

2- Zona de conforto

3- Vendas

4- Marketing

5- Novos serviços

Analisando cada um desses fatores internos e Pontos fracos, identifica-se que a empresa perdeu um pouco de sua iniciativa quando as coisas começaram a não dar tão certo. A queda na receita diminuiu a lucratividade e, junto com ela, a capacidade de investimento. Com isso, a empresa acomodou-se e deixou de investir em tecnologia, em vendas, marketing e, principalmente, no desenvolvimento de novos serviços.

A queda da receita, juntamente com outros fatores de ordem subjetiva, como a perda de confiança, levou a uma perda de iniciativa. A empresa ficou paralisada diante dos problemas que vinha enfrentando, principalmente no que diz respeito à perda de clientes e de receita.

Dessa forma, sem saber o que fazer e deixando de investir em melhorias que seriam importantes para manter a competitividade perante os concorrentes, como se viu acima, a empresa deixou de investir em tecnologia, em vendas, em marketing e, sobretudo, no desenvolvimento de novos serviços.

Com baixos investimentos, com baixa inovação, a empresa sentiu ainda mais os efeitos da queda de receita, sofrendo profundamente as consequências de tais atitudes. Os fatores internos identificados surgiram afetando o desempenho da empresa nestes 
anos, contribuindo para levarem-na à situação que chegou, com uma queda de faturamento sem igual e profunda: faturou em 2012, como se viu, 1/3 de sua maior receita, que fora em 2008, ou seja $\mathrm{R} \$ 1.400 .000,00$ e $\mathrm{R} \$ 4.400 .000,00$ respectivamente.

Segundo o professor Covey (2008, p. 29) “a confiança é uma das formas mais poderosas de motivação e inspiração", ideia que o autor completa e que se registra na sequência:

Qualquer que seja a situação, precisamos aprender a ficar bons em estabelecer, estender e recuperar a confiança - não como técnica de manipulação, mas como um meio eficaz de nos relacionarmos e de trabalharmos com os outros, e também como o meio mais eficiente de alcançarmos resultados.

Certamente, boa parte desses pontos fracos encontraram na falta de confiança um solo fértil, que deu a eles mais e mais força para se fazerem presentes, prejudicando ainda mais o crescimento da empresa nesse momento.

Sobre a importância de evitar os pontos fracos, os professores Fischmann e Almeida (2018, p. 94) refletem:

O estabelecimento do direcionamento estratégico não é algo definitivo, apenas procura-se traçar um possível caminho que valorize a utilização dos pontos fortes e evite os pontos fracos, aproveitando as oportunidades e evitando as ameaças.

\section{3- AMBIENTE ORGANIZACIONAL}

Muitos fatores contribuíram para o declínio da CAMARGO RODRIGUES. Dentre os principais, identificaram-se também alguns externos que contribuíram fortemente para o declínio. Desses, podem-se citar quatro de maior relevância que 
surgiram de forma mais acentuada a partir do ano de 2009, afetando diretamente o desempenho da empresa, que estava focada na cobrança extrajudicial de mensalidades.

Por outro lado, o escritório de advocacia também começou a apresentar sintomas de declínio depois de 2014, após a crise que atingiu o país no fim do primeiro governo Dilma, gerando PIB negativo nos anos de 2015 e 2016, como se pode notar na tabela abaixo reproduzida.

\section{EVOLUÇÃO DO PIB}

\section{Ano a ano, em \%}

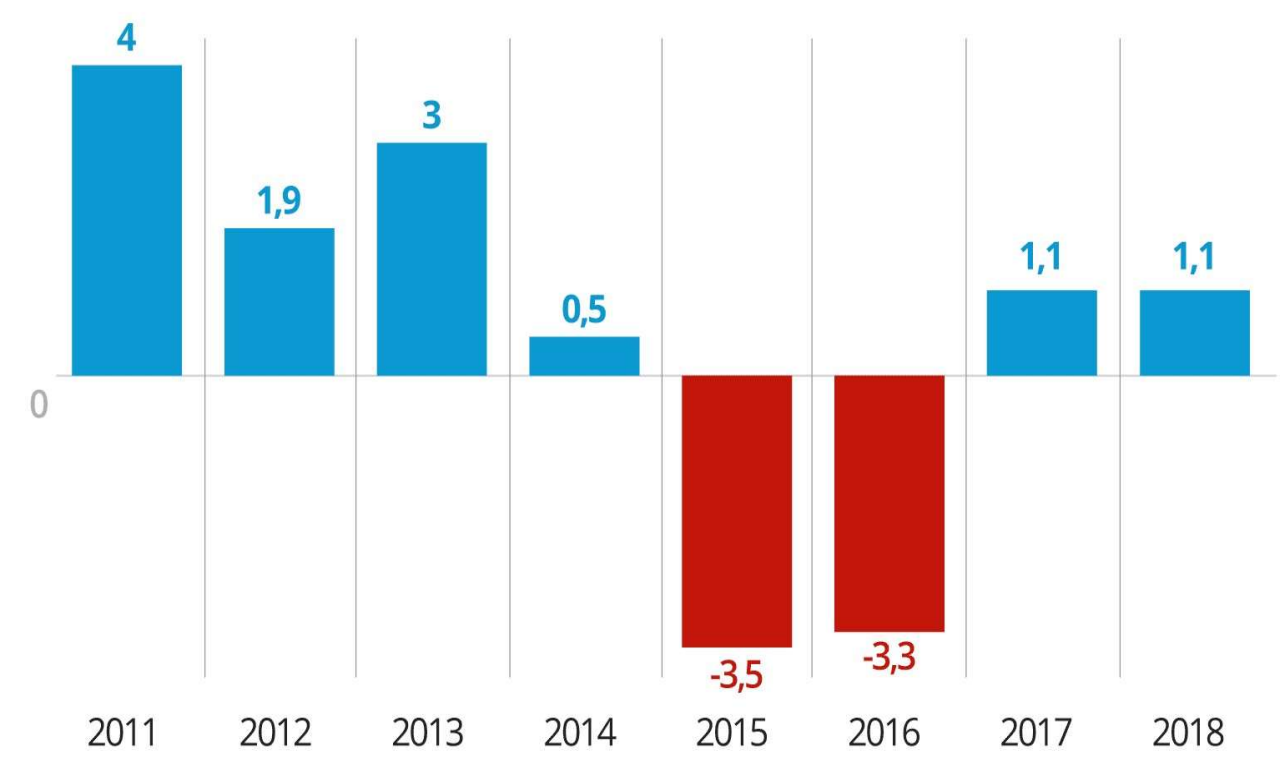

Fonte: IBGE

Figura 9 - Evolução do PIB do Brasil de 2011 a 2018

Fonte: G1 - Globo. Disponível em:

$<$ https://www.google.com/search?q=evolu\%C3\%A7\%C3\%A3o + do + pib + brasileiro\&source $=\operatorname{lnms} \&$ tbm $=\mathrm{i}$ sch\&sa=X\&ved=0ahUKEwjI1OLEt8HhAhV9IbkGHX2RCEkQ_AUIDigB\&biw=1366\&bih=590\#imgrc =3Zp19dYJ9T6aWM:>. 
Somados ao baixo desempenho econômico, seguem relacionados abaixo os principais fatores externos que contribuíram para o declínio da CAMARGO RODRIGUES.

Basicamente, identificou-se 4 (quatro) fatores principais que causaram de forma mais impactante o declínio das empresas como um todo. Cada um destes fatores causaram a queda das empresas em momentos diferentes, pois elas também nasceram em momentos diferentes. Contudo, entende-se que as duas empresas sofreram dos mesmos problemas, haja vista que estão intimamente ligadas, uma fazendo a cobrança amigável e a outra fazendo cobrança judicial de mensalidades de instituições de ensino superior privado.

Fatores Externos identificados:

1. Concorrência

2. Concentração do setor

3. PROUNI - FIES

4. Novas Tecnologias

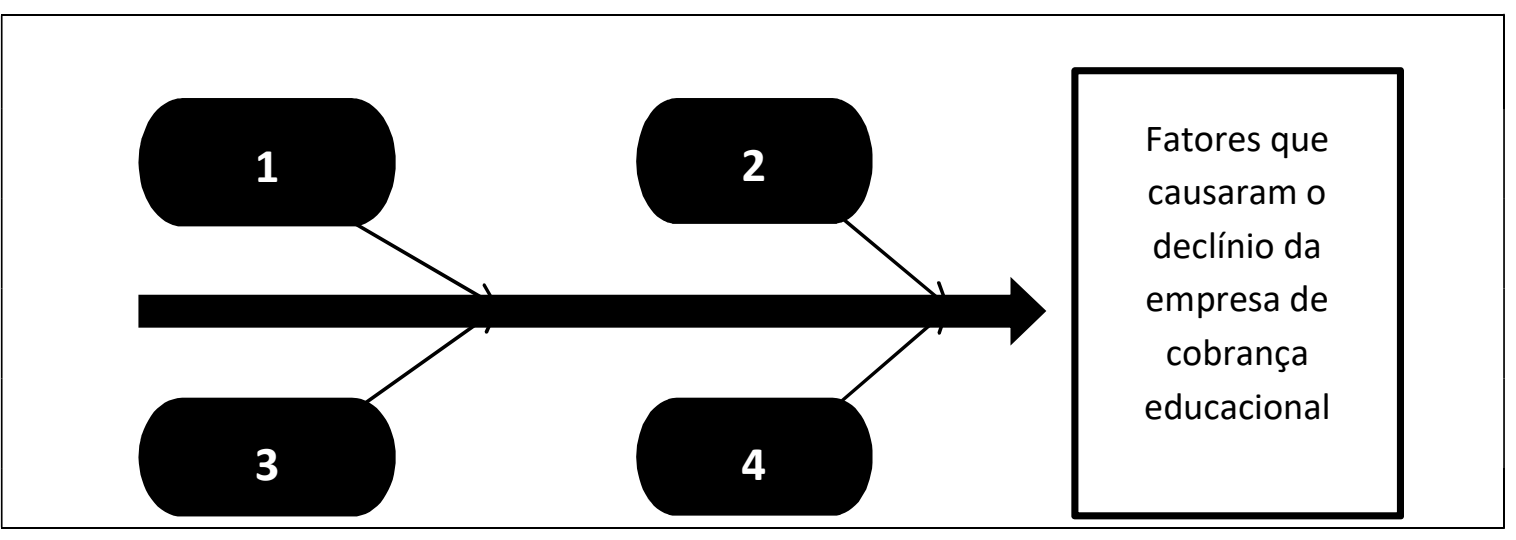

1- Concorrência

2- Concentração do Setor

3- PROUNI - FIES

4- Novas Tecnologias
- foco em preço;

- rescisão contratual;

- bolsas de estudo;

- cobrança interna;

Figura 10 - Diagrama de causa e efeito Fonte: $\mathrm{O}$ autor. 
Segundo o professor Almeida (2010, p. 33), o diagrama de causa e efeito é bastante útil para auxiliar na identificação das causas dos problemas que eventualmente a empresa precise solucionar. Para ele, "as técnicas deste método levam" à identificação de possíveis causas, que, por sucessivas quebras, tornam-se efeitos de ações menores, resultando no povoamento do diagrama, que é o que se vê acima. De acordo com o professor, "desta forma, pode-se entender como um problema prático e amplo foi dividido nos seus principais segmentos, que facilitarão a definição da questão de pesquisa, do objetivo principal da pesquisa e do surgimento dos objetivos específicos".

Dentre os fatores externos que causaram o declínio da empresa, pode-se dizer que os principais, os que mais impactaram a empresa, foram: a concorrência, a concentração do setor, o PROUNI e o FIES, e os avanços tecnológicos.

A concorrência diz respeito exatamente aos novos entrantes que surgiram com foco em preço, buscando a liderança em custo, deslocando a estratégia dentro do alvo estreito para um enfoque em custo.

A concentração do setor levou ao surgimento de grandes grupos educacionais que passaram a comprar IESP que eram atendidas pela CAMARGO RODRIGUES, o que diminuiu a carteira de clientes, uma vez que os mesmos foram incorporados pelos grandes grupos educacionais que surgiram no país, como Anhanguera e Kroton. Estes grandes grupos compraram alguns clientes que tinham a CAMARGO RODRIGUES como empresa de cobrança de mensalidades atrasadas, e estas instituições, ao serem adquiridas por esses grupos, suspenderam o encaminhamento de débitos para cobrança terceirizada, impactando diretamente na receita, como já se viu, a partir de 2008.

Depois veio o PROUNI e o FIES, sistemas que regularam a distribuição de bolsas pelo governo, as quais poderiam ser integrais ou parciais para os alunos vindos de escolas públicas e ou de baixa renda. Estes jovens eram alunos dos clientes da CAMARGO RODRIGUES e deixaram de ser inadimplentes. Isso gerou um impacto violento nas empresas, uma vez que os alunos devedores deixaram de ser devedores das IESP atendidas pela empresa de cobrança, o que por um lado foi bom, pois estes alunos estavam tendo dificuldade para honrar seus compromissos junto às instituições, porém, 
por outro lado, fez com que diminuísse o encaminhamento de débitos para as empresas cobradoras, em especial para a CAMARGO RODRIGUES.

As novas tecnologias, por sua vez, possibilitaram que as IES realizassem a cobrança internamente mediante sistemas de ERP que tinham módulos de cobrança. Puderam aperfeiçoar os serviços de cobrança interna, pois foram desenvolvidos, com as novas ferramentas de tecnologia, módulos que realizavam a cobrança emitindo relatórios de inadimplentes, disparando e-mails e fechando acordos mediante a emissão de confissão de dívida, notas promissórias e boletos, exatamente como as empresas terceirizadas faziam.

Todos esses fatores juntos causaram um grande impacto no faturamento da empresa, uma vez que possibilitaram de uma forma ou de outra que o cliente educacional resolvesse seu problema de inadimplência internamente ou com outro prestador de serviços de sua região ou que estivesse tecnologicamente mais desenvolvido, ou repassando os devedores para o governo através do financiamento educacional.

\section{4- PROBLEMA OBSERVADO}

Como se viu nos itens anteriores, a CAMARGO RODRIGUES cresceu até o ano de 2008, quando atingiu seu auge, com 80 funcionários e 4 unidades - uma matriz e 3 unidades de atendimento. Contudo, depois de 2008 iniciou-se um processo de queda que ainda não terminou. Tal processo de crescimento e queda confirma a teoria do ciclo de vida formulada por Adizes (1993). Ela nasceu, cresceu, atingiu a maturidade e, depois, entrou em declínio. Esse processo levou mais ou menos 13 anos.

Tabela 6 - Linha do tempo das empresas

\begin{tabular}{|l|l|l|l|l|l|}
\hline \multicolumn{1}{|c|}{1994} & \multicolumn{1}{|c|}{1995} & \multicolumn{1}{c|}{1996} & \multicolumn{1}{c|}{2000} & \multicolumn{1}{c|}{2009} & \multicolumn{1}{c|}{2012} \\
\hline Estabiliza- & Inadimplênc & Fundação da & Concorrência & Constituiçã & Pior \\
São da & ia- & Camargo & Consolidação & o da RAF & receita \\
economia - & cia & Rodrigues - & do setor, & Advogados & anual \\
Plano Real & educacional & cobrança & FIES e & - cobrança & desde a \\
& de até 40\% & amigável & Tecnologia & judicial & fundação \\
& & & & & \\
\hline
\end{tabular}

Fonte: $\mathrm{O}$ autor. 


\section{5- QUESTÃO DE PESQUISA}

O contexto acima apresentado e as dificuldades relatadas levaram ao problema a ser resolvido, que por sua vez levou à realização do presente estudo, o qual pretendia identificar, com base na teoria, COMO reverter este processo de declínio da empresa, ou seja:

\section{COMO RETOMAR O CRESCIMENTO DA EMPRESA DE PRESTAÇÃO DE SERVIÇOS DE COBRANÇA EDUCACIONAL - CAMARGO RODRIGUES?}

Este era o problema principal $\mathrm{e}$, juntamente com ele, vinham vários questionamentos surgidos, perguntas sem respostas fáceis, perguntas que pareciam significar que a empresa estava perdida, sem saber o que fazer:

- O que poderia ser feito para que a empresa voltasse a crescer?

- Como atingir um estágio economicamente sustentável?

- Como recuperar e manter a lucratividade?

- Como ser mais eficiente e mais eficaz?

- Como capturar mais valor para si?

- Como criar mais valor para os clientes?

\section{6- OBJETIVOS}

O objetivo seria, portanto, encontrar alguma solução que possibilitasse a retomada do crescimento da empresa, pois, se ela continuasse naquela direção, certamente bons frutos não seriam colhidos. Assim, tomando por base os serviços que a empresa já vinha prestando, assim como as dores que o cliente vinha sofrendo por causa dos efeitos da crise pela qual o país vinha passando, entendeu-se que poderia ser interessante desenvolver um novo serviço que aumentasse o volume de cobranças amigáveis e que melhorasse o fluxo de caixa dos clientes, fidelizando os ainda mais à empresa. 
Fez-se a seguinte pergunta: por que não comprar este tipo de débito, antecipando para o cliente parte desta receita, desobrigando-o de ter que aguardar os frutos do trabalho de cobrança? Além disso, a compra dos recebíveis educacionais poderia alimentar a carteira de cobrança da empresa com títulos que são a sua especialidade.

De fato, este novo serviço poderia então ser visto como uma solução, tanto para a CAMARGO RODRIGUES como para os clientes dela, pois tal negociação poderia gerar um ganha-ganha para ambos.

Com isso, como se verá a seguir, o presente estudo procurou propor este novo serviço: compra de recebíveis educacionais vencidos.

\subsection{1- OBJETIVO PRINCIPAL}

O objetivo principal da pesquisa:

Desenvolver um novo serviço que possibilite retomar o crescimento da CAMARGO RODRIGUES.

\subsection{2- OBJETIVOS COMPLEMENTARES}

a. Pesquisar junto aos clientes a aceitação/interesse pelo serviço;

b. Chegar a preços competitivos através de um estudo financeiro e estatístico para compra dos recebíveis educacionais vencidos;

c. Ter um contrato de cessão de crédito.

Quanto ao item "a", foi feito um estudo financeiro e estatístico com um matemático, visando estimar o preço correto do serviço, trazendo a valor presente o custo dos recursos a serem recuperados e estimando quando isso ocorreria, pois, como se disse anteriormente, cada devedor negocia o pagamento de sua dívida a partir de um determinado momento e, na maioria das vezes, de forma parcelada, podendo ainda romper o acordo firmado. Portanto, seria necessário identificar o tempo que o devedor 
levaria para comparecer para fazer o acordo, a probabilidade de ele cumprir o acordo realizado e o tempo mais provável de quitação, sempre considerando o valor do dinheiro utilizado na compra deste débito à vista.

Quanto ao item "b", pretendia-se analisar como os clientes receberiam o novo serviço e, sobretudo, avaliar se eles teriam real interesse nele. Isso acabou sendo feito em reuniões pessoais com os dois maiores clientes do escritório, os quais já haviam manifestado interesse na venda de débitos vencidos mais de um ano antes.

Quanto ao item “c”, as regras do serviço de compra de recebíveis educacionais vencidos envolvem uma cessão de crédito por parte da instituição de ensino para o novo credor. Tal cessão exige a elaboração de um instrumento particular de cessão de crédito, ou seja, de um contrato para regular todas as condições, descrevendo a operação como um todo e anexando um relatório com a relação completa dos devedores e dos débitos que serão cedidos. Na relação de devedores deverá conter a qualificação completa dos devedores, nome, RG, CPF, endereço residencial e eletrônico, número de telefone fixo e celular, além de dados acadêmicos, como número de matrícula e curso.

\subsection{3- ESTRUTURA DA DISSERTAÇÃO}

O trabalho foi realizado de forma estruturada, iniciando-se, como se viu, com a identificação do problema a ser resolvido, que foi definido com base na experiência profissional do autor, o qual é proprietário de uma empresa de cobrança educacional desde 1996.

Em seguida, identificado o problema, fez-se uma análise SWOT analisando os pontos fortes e fracos da empresa, assim como as ameaças e as oportunidades, visando identificar as causas do problema, o que foi feito mediante a aplicação da espinha de peixe.

Identificadas as causas do problema, passou-se a buscar uma solução para o mesmo na literatura, buscando através de todo o referencial teórico uma saída para o problema que havia sido identificado. 
A fundamentação teórica usada foi principalmente a relativa ao que fazer para solucionar o problema da empresa, pois, num primeiro momento, não se sabia qual seria a solução, daí termos pesquisado muitos autores, que estimularam o desenvolvimento de um pensamento inovador, flexível, de novas estratégias, procurando mais eficiência e eficácia, agilidade e confiabilidade.

Além disso, a teoria pesquisada estimulou bastante a ação de identificar oportunidades no mercado, assim como ficar atento aos custos, mas focado em sua expertise. Ficou claro que a solução deveria ser algo sinérgico ao que já vinha sendo feito pela empresa, aproveitando os conhecimentos, competências e habilidades do empreendedor.

A seguir, abordam-se a metodologia usada para chegar à solução do problema e ao seu desenvolvimento; mas, como se verá, há muito ainda a ser estudado, pois a solução é realmente complexa e de alto risco, o que obriga, ao nosso ver, serem dados passos firmes - devagar e sempre.

Finalmente, apresenta-se detalhadamente a solução encontrada, que é bastante ousada e ainda exigirá muito trabalho para seu aperfeiçoamento, mas sem dúvida alguma poderá transformar a realidade da empresa como um todo, tendo em vista o alto grau de escalabilidade da solução proposta,, pois o mercado educacional brasileiro representa em torno de 10 bilhões de reais por ano, com uma inadimplência média de $10 \%$, ou seja, de 1 bilhão por ano.

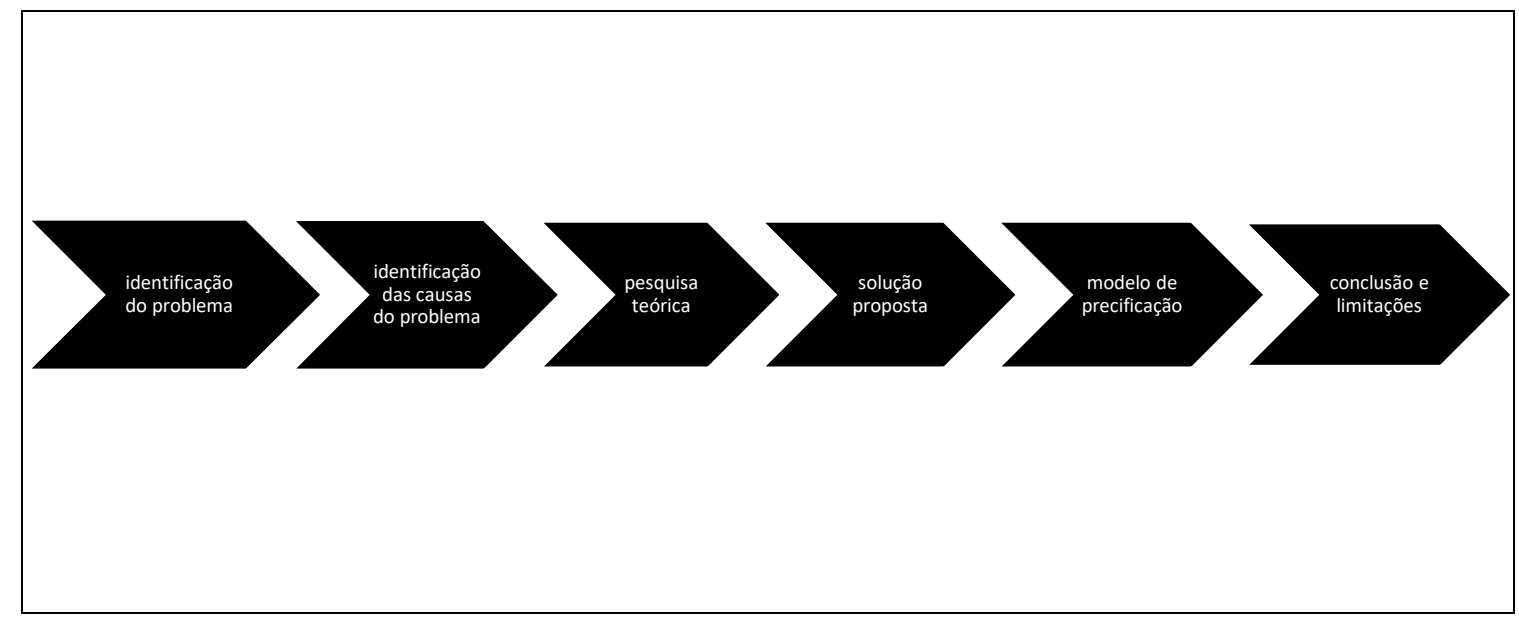

Figura 11 - Estrutura da dissertação Fonte: Autor. 


\section{3- REFERENCIAL TEÓRICO}

A administração de empresas é assunto recorrente em muitos estudos realizados por professores em todo o mundo. Alguns desses professores colocaram em livros suas teorias, algumas das quais foram estudadas pelo autor desta pesquisa antes de adentrar no mestrado profissional, outras foram consultadas ao longo do curso e, agora, todas foram revisitadas para a presente pesquisa, sobretudo visando encontrar respostas para as novas perguntas que surgiram, dentre elas, o que poderia ser feito para que fosse possível a retomada do crescimento da CAMARGO RODRIGUES e da RAF ADVOGADOS?

Como demanda o mestrado profissional, partiu-se da prática para a teoria e voltou-se à prática com uma solução para o problema de pesquisa, visando solucionar adequadamente o problema. Lembre-se que, eventualmente, a pesquisa pode também concluir que a solução proposta não é viável ou que tem limitações irreparáveis.
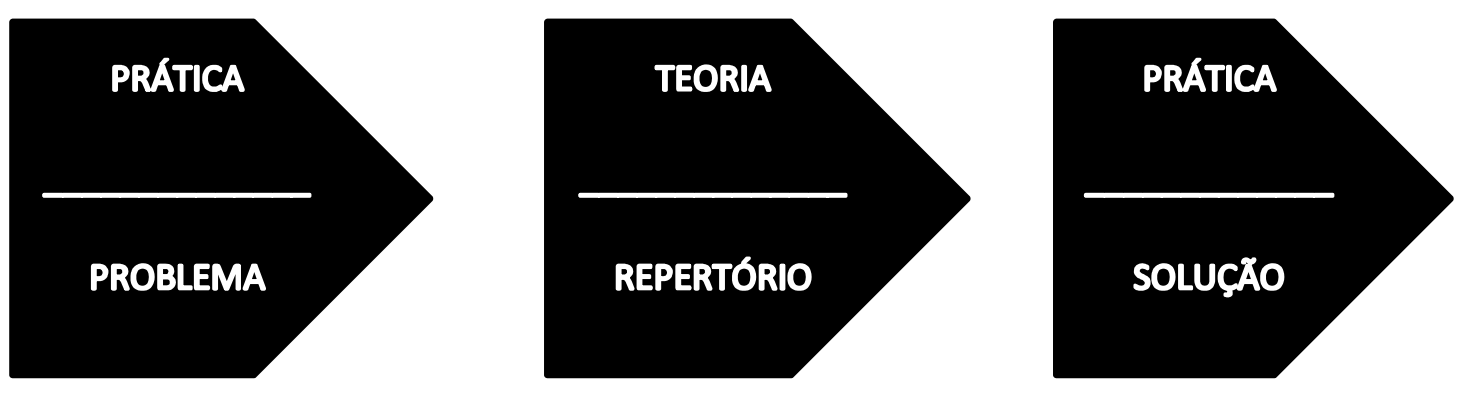

Figura 12 - Problema, repertório e solução

Fonte: Autor

\section{1- PLANEJAMENTO ESTRATÉGICO}

O planejamento estratégico é fundamental para o sucesso das empresas e de seus empreendimentos, sendo algo que a CAMARGO RODRIGUES sempre valorizou. A isso reputa-se o fato de a empresa ter 22 anos de existência, o que já é uma vitória em um país como o Brasil, onde empreender é uma tarefa bastante difícil. Segundo o mestre 
Anselmo (1995, p. 120), o planejamento estratégico pode sofrer mudanças, as quais devem estar em consonância com as forças externas e internas da empresa:

\begin{abstract}
As mudanças estratégicas são determinadas pelo contexto organizacional, ou seja, pelo conjunto das forças externas e internas à organização. As forças externas, de natureza econômica, social, política, tecnológica e competitiva, na medida em que sofrem contínuas mudanças, condicionam o desempenho das empresas, que buscam compatibilizar suas estratégias, estruturas e sistemas, tendo em vista os objetivos individuais e coletivos traçados para a empresa. As forças internas, de natureza política e cultural, atuam sobre a organização de duas formas distintas: na manutenção das estratégias, estruturas e sistemas, a fim de preservar as relações de poder e os valores e pressupostos básicos compartilhados pela coalizão de poder dominante; ou na alteração das estratégias, estruturas e sistemas, a fim de compatibilizá-los com uma nova coalizão de poder que busca alterar a cultura vigente tendo em vista novos objetivos e valores pretendidos para a empresa.
\end{abstract}

Nesse sentido, também se entende que as empresas devem ser eficientes e eficazes, contudo muitos empresários não sabem a diferença entre as duas coisas. Nem sempre uma empresa eficiente é eficaz a ponto de atingir seus objetivos. Para ilustrar esse ponto, buscam-se as orientações de Almeida (2010, p. 19), que ressaltam a importância de entender a diferença entre eficiência e eficácia:

Aprender a ser eficaz é mais difícil do que aprender a ser eficiente, pois a eficiência é uma medida racional, que pode ser comprovada e medida cientificamente, e a eficácia, embora saibamos que existe, não pode ser medida. Algumas pessoas explicam a eficácia como sendo atingir os objetivos e nesse caso a eficácia poderia ser medida em função de atender ao que foi planejado. Essa definição estaria certa se pudéssemos ter certeza de que a formulação dos objetivos foi adequada em atender às necessidades dos stakeholders, mas como não é possível ter certeza de que está atendendo adequadamente aos stakeholders não é correto aceitar que a eficácia seja atender aos objetivos.

Nós temos duas formas de desenvolver o pensamento: 
- racional, em que as decisões são claras e precisas, podendo-se avaliar quantitativamente; $\mathrm{e}$

- emocional e criativa, na qual as decisões não são precisas, seguem a intuição e a arte do decisor.

O planejamento estratégico se utiliza dessas duas formas de pensar, mas devese entender que são muito diferentes, embora se complementem, sobretudo porque a efíciência ajuda a eficácia.

De modo geral, a eficiência está mais voltada para o presente e a eficácia mais voltada para o futuro, ficando a primeira mais ligada aos aspectos internos da empresa e a segunda aos aspectos organizacionais, explica o professor. Na CAMARGO RODRIGUES sempre houve a preocupação em ser eficiente operacionalmente, cuidando para reduzir os pontos fracos da empresa e tirar vantagem dos pontos fortes. Por outro lado, buscou-se ter visão de futuro do negócio, mas esta é uma tarefa muito difícil. Enxergar as oportunidades e as ameaças que porventura surjam é complicado.

\section{2- BUSCA DA LIDERANÇA}

Outro ponto importante para o sucesso da empresa é a liderança. Muitos autores destacam, como principais características dos líderes, o caráter e a competência. Os professores Costa e Almeida (2002) abordam vários temas escritos por inúmeros colaboradores. O colaborador Luis Gaj (COSTA E ALMEIDA, 2002, p. 94) escreveu sobre liderança, onde destaca as 6 (seis) qualidades que um líder deveria ter para conduzir uma empresa:

Entre diversas qualidades necessárias para um líder exercer seu papel de condutor de outras pessoas ou outros líderes, podem-se destacar seis características ou aspectos que consideramos importantes.

Sendo de propósito: saber o que deseja de forma clara, para poder transmitir a seus seguidores e para poder unir esforços em torno desse propósito. 
Capacidade de construir uma visão: significa que o líder visionário precisa ser capaz de enxergar aonde quer levar sua organização no futuro. A visão é uma antecipação do desenvolvimento desejado.

Gerar confiança, arriscar e aprender: a confiança é conquistada pelas realizações confirmadas. O risco é inerente a qualquer atividade e precisa ser assumido. Sem risco não existe futuro possível. Aprender significa não achar que já sabe tudo. Ter a humildade necessária para atualizar-se constantemente, e abertura e disposição para aprender.

Significado da visão: uma visão deve apresentar para toda a organização um significado pelo qual valha a pena concentrar esforços e transformá-los em ação concreta. Esse significado é um sentido maior, que pode ser atender a uma carência ou necessidade, atuação ética, um crescimento que oferece novas oportunidades, um desafio especial, ou outras formas motivadoras.

Visão compartilhada: o que significa que não é suficiente alguém ter uma visão e não divulgá-la entre todos os que devem pô-la em prática. E também divulgar não é suficiente. É preciso compartir, assumir a visão em conjunto com a equipe, para que ela se torne realidade.

Equilíbrio intelectual: vida familiar regrada, equilíbrio entre amizades, leituras, exercício físico, boa alimentação e trabalho, sem dúvida, auxiliam o líder em suas funções. Contribui também sua experiência mundial, ou seja, sua visão de mundo.

$\mathrm{Na}$ CAMARGO RODRIGUES, sempre houve muita preocupação em desenvolver o líder e as lideranças, e pôde-se ver na prática a importância dos pontos acima destacados, quais sejam: propósito, visão, confiança, arriscar, aprender e equilíbrio intelectual. Sem dúvida nenhuma, são características importantíssimas para obter sucesso como empreendedor e assim conseguir encontrar soluções para os problemas de gestão.

\section{3- RELACIONAMENTO COM CLIENTES}

Outro aspecto fundamental para o sucesso de qualquer empresa é o relacionamento com os clientes e a confiança que deve existir neste relacionamento. $\mathrm{Na}$ 
atividade exercida pela CAMARGO RODRIGUES, a confiança é algo primordial, pois a empresa se encarrega de cobrar dos devedores e repassar para o credor os valores efetivamente recebidos. Esta é uma atividade extremamente delicada que requer alto nível de confiança.

No que tange à confiança no relacionamento com os clientes, Francesconi (2016) tratou do assunto, deixando claro que a confiança entre contratante e contratado é um fator sumamente importante, que pode, até mesmo, reduzir custos:

Pode-se quantificar a confiança através da relação direta de quanto maior a confiança, maior a velocidade, seja de comunicação, de decisão, de execução de alguma tarefa e assim decorrem menores custos.

A seguir, veremos como conhecer o problema. Algo fundamental para encontrar uma solução para o mesmo.

\section{4- CONHECENDO O PROBLEMA}

Outro aspecto importante é ter uma visão realista do problema, que pode ser interno ou externo, e, como nos ensinou Ohno (1997), sobre o sistema de produção da Toyota, é necessário que as pessoas envolvidas no processo trabalhem em equipe. Para isso, segundo o autor, torna-se imperativo conhecer o problema, e a Toyota tinha um problema: "O nosso problema era como cortar custos e, ao mesmo tempo, produzir pequenas quantidades de muitos tipos de carros."

A CAMARGO RODRIGUES tinha um problema: como retomar o crescimento? Para responder a isso era imperativo conhecer o profundamente problema, mais ainda, conhecer as causas do problema, para então buscar uma solução para o mesmo. 


\section{5- VISÃO DE UM FUTURO INOVADOR}

Em busca de resolver o problema da CAMARGO RODRIGUES, percebeu-se que havia necessidade de uma visão de futuro, de criar algo novo. Para isso, foram essenciais os ensinamentos do professor Brown (2010), que, em seu livro revolucionário, nos apresentou o Design thinking, que é uma metodologia poderosa para decretar o fim das velhas ideias.

Tim Brown divulgou o seu método em 2010, e ele fala que, para as empresas crescerem, sejam elas quais forem, há a necessidade de CRIAR coisas novas, revolucionárias. A seguir, registra-se um quadro que foi apresentado por este autor na disciplina de gestão de projetos do Prof. Dr. Amaru:

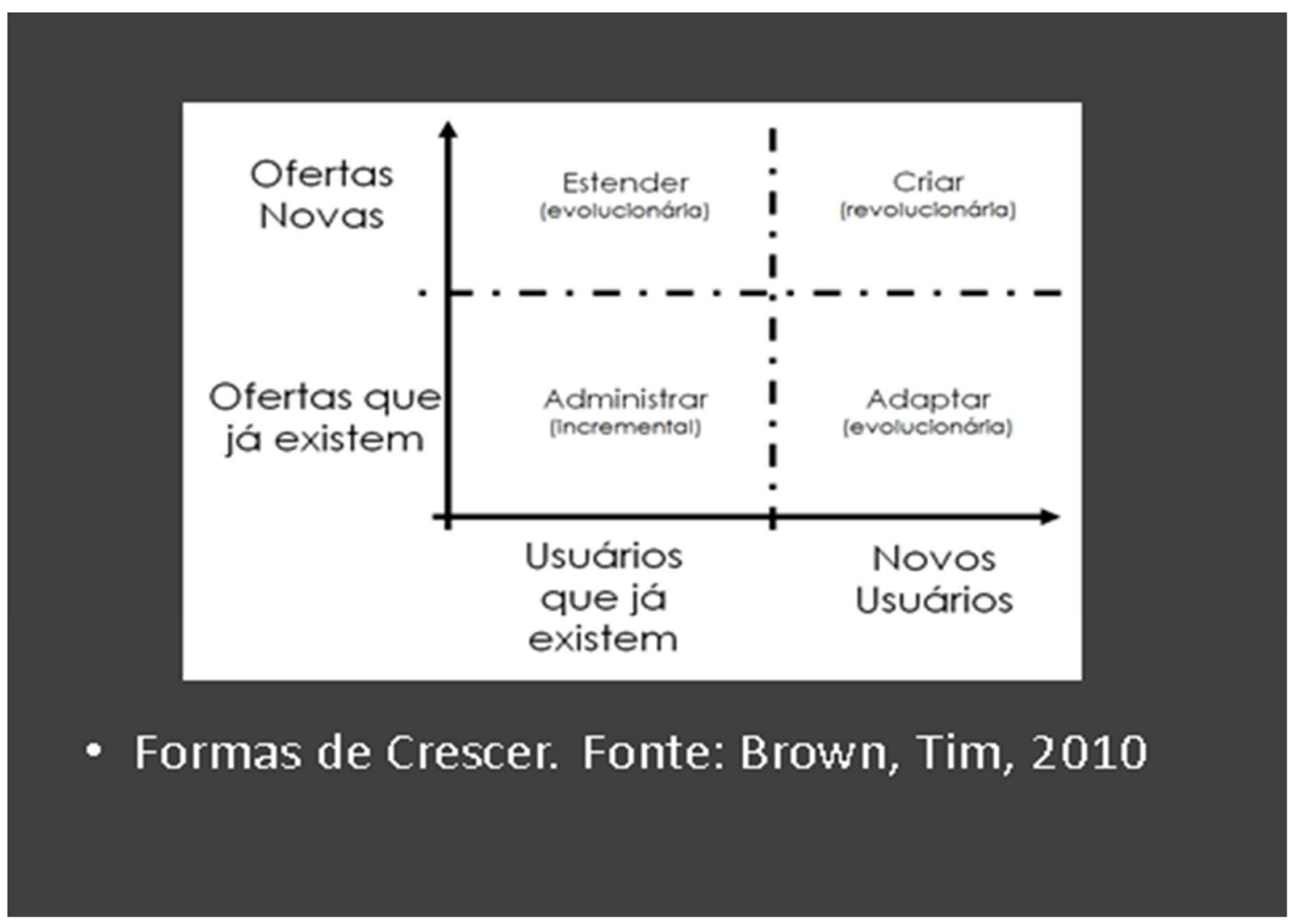

Figura 13 - Formas de crescer

Fonte: O autor. Trabalho de conclusão da disciplina de Gestão de Projetos. Slide PPT, 2018. 
Visualizando as opções deste quadro, podemos notar que a CAMARGO RODRIGUE, criou algo novo quando o desenvolveu a cobrança extrajudicial. Após este período criou-se a RAF Advogados pois o serviço de cobrança judicial ainda não era muito conhecido. Agora vimos a necessidade de desenvolver um novo serviço, inovador e revolucionário para a retomada do crescimento.

\section{6- RECONHECIMENTO DE OPORTUNIDADE}

Outro aspecto importante no estudo realizado foi conhecer e estudar o tema do empreendedorismo aos olhos do professor Shepherd (2014, p. 86), que relata que os empreendedores precisam ter condições de reconhecer oportunidades de negócio a fim de que possam expandir suas empresas. Essa visão nos auxiliou a olhar para o negócio com confiança nas oportunidades que eventualmente estão sendo visualizadas, mas que estariam sendo ignoradas, seja por miopia, seja por insegurança ou inexperiência:

Alguns empreendedores precisam da capacidade de reconhecer oportunidade de negócio, o que é fundamental para o processo empreendedor e para a expansão de uma empresa. Uma oportunidade de negócio representa uma possibilidade para um empreendedor atender com êxito a uma necessidade insatisfeita suficientemente grande, o que resulta em vendas e lucros.

O reconhecimento de uma oportunidade em geral é consequência do conhecimento e da experiência do empreendedor individual e, onde for pertinente, da empresa empreendedora. Esse conhecimento prévio resulta de uma combinação de educação e experiência, e a experiência relevante pode ser o trabalho relacionado ou o resultado de diversos eventos ou experiências pessoais. O empreendedor deve estar consciente desse conhecimento e dessa experiência e ter vontade de entendê-los e de usá-los. Os outros fatores importantes nesse processo são a atenção empreendedora e as redes empreendedoras.

Há um efeito de interação entre a atenção empreendedora e o conhecimento prévio dos mercados e dos problemas do cliente por parte do empreendedor. Os empreendedores que conseguem reconhecer oportunidades significativas de negócio se encontram em uma posição estratégica para concluir com êxito o processo de planejamento e desenvolvimento do produto e lançar novos empreendimentos com sucesso. 


\section{7- LEI 9870/99}

O autor do presente estudo, Rodrigues (2004), menciona que "o devedor educacional passa a ser realmente inadimplente a partir do $90^{\circ}$ (nonagésimo) dia, pois até este momento ele é visto pelas instituições de ensino como estando em atraso".

De fato, uma coisa é o devedor estar atrasado com seus compromissos, outra coisa é ele estar efetivamente inadimplente, ou seja, sem perspectiva de pagar no curto prazo, precisando de um parcelamento para quitar o débito que está em aberto junto ao credor.

Vale lembrar que a principal causa da inadimplência é o desemprego, segundo dados da ASCSP. Uma pessoa desempregada não tem condições de pagar suas dívidas no curto prazo. Ela precisa parcelar esse débito e, se possível, pagar cada mensalidade em aberto em duas parcelas no acordo; assim, se estiver devendo 4 mensalidades, seria melhor parcelar em 8 vezes (1 para 2).

Por outro lado, a instituição de ensino credora necessita receber esse valor o mais rápido possível para poder honrar seus compromissos, como salários, impostos, manutenção predial, pois nem sempre a instituição tem capital de giro suficiente para cobrir esses valores.

Além desses dois pontos, aluno desempregado e instituição sem capital de giro, vale destacar que o artigo $6^{\circ}$ da Lei 9.870/99 diz que o devedor só se sujeitará às medidas legais e administrativas caso a inadimplência perdure por mais de 90 dias. Lembre-se que as medidas legais seriam a cobrança judicial do débito e as medidas administrativas seriam a negativação nos órgãos de proteção ao crédito, sendo vedadas penalidades pedagógicas como retenção de documentos ou suspensão de provas.

\section{8- A SOLUÇÃO}

Por fim, após toda a experiência do autor, a identificação clara do problema e de suas causas, a definição dos objetivos principal e complementares, bem como a análise 
de todas as referências teóricas, chegou-se à solução do problema, que, conclui-se, passava pelo desenvolvimento, pela criação, pela iniciativa, pela coragem de lançar um novo serviço, que, no caso, foi a COMPRA DE RECEBÍVEIS EDUCACIONAIS VENCIDOS de IESP.

Agora, demonstrar-se-á o trabalho prático realizado para verificar se a solução proposta é realmente viável e se ela atende às necessidades da empresa e de seus clientes.

Entende-se que, de forma geral, a solução do problema deve cumprir um papel duplo, qual seja:

1 - Agregar valor para os clientes.

2 - Capturar valor para a CAMARGO RODRIGUES;

Assim, espera-se que o novo serviço apresente tais características, muito embora se saiba que o resultado do estudo pode ser tanto positivo quanto negativo.

A seguir, serão apresentados os métodos e as técnicas de pesquisa que foram aplicados ao presente estudo, visando desenvolver e validar a solução proposta tanto positiva quanto negativamente. 


\section{4- MÉTODOS E TÉCNICAS DE PESQUISA}

\section{1- PESQUISA-AÇÃO}

Segundo David Tripp, “pesquisa-ação é uma forma de investigação-ação que utiliza técnicas de pesquisa consagradas para informar a ação que se decide tomar para melhorar a prática".

Neste sentido, a metodologia utilizada foi a pesquisa-ação (YIN, 2005), com observação participante. Este método de pesquisa prescreve que uma pesquisa pode ser quantitativa, qualitativa ou de natureza exploratória.

A pesquisa-ação é uma metodologia que vem sendo bastante utilizada em projetos de pesquisa na pós-graduação profisssional. Ela tem como ponto central a pesquisa de campo participativa para solucionar o problema de pesquisa, podendo ser definida como uma pesquisa coletiva formada por um ou mais participantes em situações sociais.

Por meio da pesquisa-ação pretendia-se que, ao final, ficasse comprovado, utilizando os dados que a própria empresa possui, que a solução proposta para o objeto da pesquisa é viável e que a solução proposta poderá capturar valor para empresa e entregar valor aos clientes. Nesse sentido, entende-se a pesquisa-ação como sendo toda a tentativa continuada, sistemática e empiricamente fundamentada de aprimorar a prática.

A forma inicial de pesquisa-ação é caracterizada pela colaboração entre o pesquisador, especialistas e práticos, integrantes da pesquisa. No presente estudo essa diretriz se confirmou, porque foi necessário o desenvolvimento, por um especialista, de um modelo matemático que possibilitasse a precificação da solução proposta para o problema, ou seja, do novo serviço de compra de recebíveis vencidos.

O aspecto inovador da pesquisa-ação deve-se principalmente a três pontos: caráter participativo, impulso democrático e contribuição à mudança social. No presente estudo participaram o Prof. Dr. Martinho Isnard Ribeiro de Almeida, como orientador, o matemático Ivan Ferraz, que desenvolveu o modelo de precificação, e 2 
(dois) clientes do autor, que dirigem instituições de ensino superior. Uma delas com 10 faculdades e a outra com 115 faculdades, localizadas principalmente no Estado de São Paulo.

\section{2- ESPIRAL DE REFLEXÃO}

De modo geral, a pesquisa-ação possibilita que se investigue continuamente o problema, e este processo poderá ser contínuo como uma espiral de reflexão e ação, onde cada espiral inclui:

- Diagnosticar problema prático que se quer resolver;

- Planejar estratégias de ação;

- Aplicar as estratégias de ação;

- Avaliar os resultados;

- Proceder aos mesmos passos para a nova situação prática.

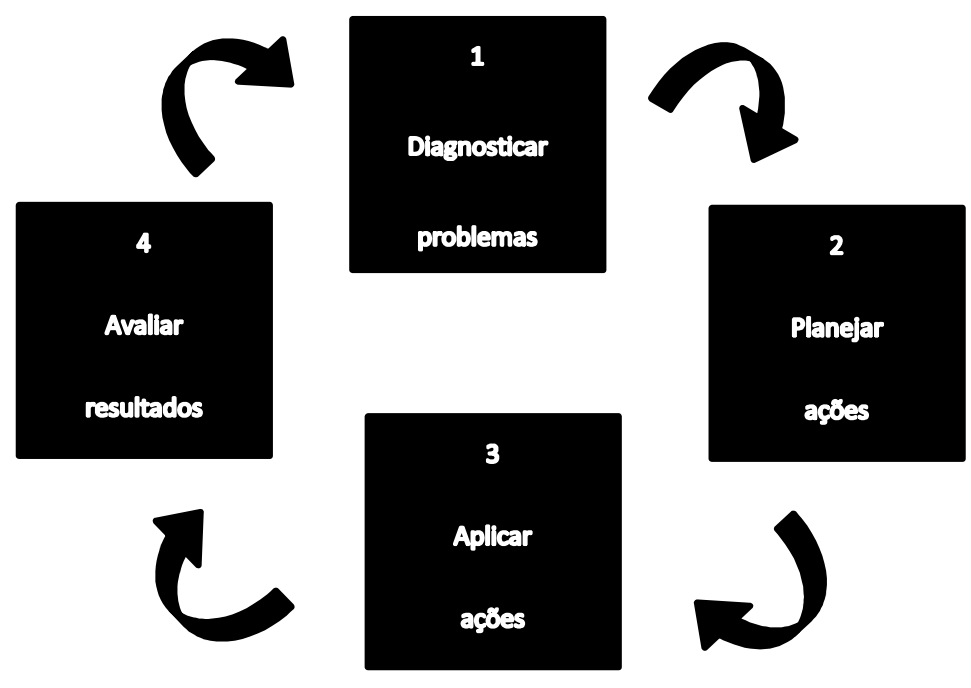

Figura 14 - Espiral de Reflexão

Fonte: Adaptado de Elliot (1997, p.17) 
1- No presente estudo, inicialmente diagnosticou-se como sendo o problema central 'como retomar o crescimento da CAMARGO RODRIGUES?', pois a empresa de cobrança, depois de 2008, passou a ter um crescimento negativo.

2- Num segundo momento, analisado o problema e suas causas, identificou-se, no planejamento de ações, que sua solução poderia ser o lançamento de um novo serviço por parte da empresa, que seria a compra de recebíveis vencidos.

3- Em seguida, o terceiro passo foi desenvolver e aplicar a solução hipotética para verificar se ela realmente teria êxito.

4- Finalmente, fizeram-se alguns ajustes para chegar ao serviço final, que poderá ser aperfeiçoado ao longo do tempo.

Assim, foi feita uma pesquisa-ação com aplicação-teste acerca do novo serviço que fora pensado como solução do problema. Além disso, realizou-se uma pesquisa teórica e prática, visando identificar os serviços existentes no mercado semelhantes ao serviço novo que está sendo proposto, para tomar conhecimento de como são eventualmente oferecidos no mercado e ver, se possível, como eles funcionam.

Depois, analisaram-se as carteiras existentes no escritório para verificar se o que foi proposto alcançaria os resultados esperados e se o novo serviço seria mesmo uma solução viável para o problema que se pretendia enfrentar, qual seja, a queda de receita por falta de encaminhamento de débitos por parte das instituições de ensino que supostamente estivessem com dificuldades de fluxo de caixa.

\section{3- PESQUISA EXPLORATÓRIA QUALITATIVA}

A pesquisa exploratória qualitativa realizada avaliou a receptividade por parte de 2 (dois) clientes de grande porte, se teriam realmente interesse pelo novo serviço, e, mais ainda, se este serviço iria efetivamente solucionar o problema de capital de giro e de fluxo de caixa que estas IESP vêm enfrentando devido à crise que o Brasil vem passando desde 2014. 
Tabela 7 - Entrevistas realizadas

\begin{tabular}{|l|l|l|}
\hline & \multicolumn{1}{|c|}{ EMPRESA A } & \multicolumn{1}{c|}{ EMPRESA B } \\
\hline FATURAMENTO APROX. & 50 MILUHÕES ANO & 250 MILHÕES ANO \\
\hline NR ALUNOS APROX. & 4.000 & 30.000 \\
\hline TICKET MÉDIO & R\$ 1.000,00 & R\$ 700,00 \\
\hline ENTREVISTADO & DIRETOR GERAL & DIRETOR FINANCEIRO \\
\hline DATA & $13 / 12 / 2018$ & $26 / 10 / 2018$ \\
\hline RELAÇÃO & CLIENTE & CLIENTE \\
\hline TIPO & PRESENCIAL & PRESENCIAL \\
\hline NR DE FACULDADES & 10 & 115 \\
\hline RESULTADO & ACEITAÇÃO IMEDIATA & ACEITAÇÃO IMEDIATA \\
\hline
\end{tabular}

Fonte: $\mathrm{O}$ autor.

As entrevistas foram realizadas mediante diálogo presencial, onde foi exposto ao entrevistado o serviço que havia sido desenvolvido no mestrado profissional e questionava-se basicamente se havia interesse por parte da instituição na contratação do mesmo. A recepção foi ótima. Os dois clientes pesquisados aceitaram de imediato a proposta e elogiaram a iniciativa.

De fato, o caixa das instituições de ensino, em sua grande maioria, ficou muito baixo com a crise econômica de 2014, que, consequentemente, com a queda do crescimento econômico, gerou um aumento do desemprego, limitando inclusive os recursos de financiamento do governo - FIES e levando o Brasil a uma das maiores recessões de sua história.

Foram pesquisados no Google scholar artigos e dissertações, a fim de verificar se já existia algo semelhante, bem como buscou-se averiguar, em sites de bancos, factorings e fundos de direitos creditórios que trabalhassem com a compra de recebíveis. Identificou-se que muitos trabalham com a compra de títulos a vencer, mas, naquele momento, não se encontrou nenhum serviço semelhante voltado exclusivamente ao setor educacional para compra de mensalidades vencidas.

Em suma, utilizou-se o método de pesquisa-ação tendo o autor como observador participante, cuja abordagem foi quantitativa e qualitativa de natureza exploratória, com pesquisa teórica na literatura e em fontes secundárias. 


\section{5- SOLUÇÃO PROPOSTA PARA O PROBLEMA}

Para solucionar o problema da queda do faturamento da empresa de cobrança educacional - o que supostamente ocorreu pelo surgimento de novos entrantes, concentração do setor, financiamento público e avanço das ferramentas tecnológicas, além de fatores internos limitantes, conforme analisado anteriormente - e auxiliar na retomada do crescimento, desenvolveu-se um novo serviço que poderá gerar aumento de receita por oferecer aos clientes algo inédito no setor educacional de cobrança - a Compra de Recebíveis Educacionais Vencidos.

\section{1- COMPRA DE RECEBÍVEIS EDUCACIONAIS VENCIDOS}

A Compra de Recebíveis Educacionais Vencidos (CREV) é um serviço novo. Mais do que isso, é um serviço inédito, único na indústria de cobrança educacional. Os próprios clientes da CAMARGO RODRIGUES afirmaram isso. Sendo assim, este pode ser um serviço que possibilite novamente uma estratégia de diferenciação em um alvo estreito, em um segmento particular que é a compra de recebíveis educacionais vencidos de instituições de ensino privado.

A Compra de Recebíveis Educacionais Vencidos, que nada mais é do que a compra de mensalidades após seu vencimento, poderá gerar a retomada do crescimento da CAMARGO RODRIGUES. Como se disse, este é um serviço novo, que ainda não existe no mercado, pois, atualmente, a operação mais realizada é a antecipação de recebíveis. A antecipação de recebíveis ocorre quando a instituição de ensino privado desconta em bancos os boletos de mensalidades a vencer, antecipando receita futura. Portanto, essa operação é realizada antes do vencimento das mensalidades e já é realizada pelo setor bancário e de fomento mercantil em larga escala. Essa operação de crédito permite que a instituição de ensino receba o dinheiro das mensalidades antes de seu vencimento, possibilitando que o caixa da instituição seja abastecido com recursos que ela receberia alguns dias depois, haja vista que são operações de curto prazo. $\mathrm{Na}$ 
prática, a IESP envia para a instituição financeira um lote de mensalidades a vencer e, em contrapartida, o banco antecipa uma parte deste lote para a instituição.

Neste caso, os valores não recebidos pelas instituições financeiras em seu vencimento são devolvidos às IESP por falta de pagamento. Posteriormente, estes valores passarão a compor a massa de inadimplentes, pois são mensalidades que não foram pagas pelos alunos, passando a ser classificados como recebíveis vencidos, de acordo com este projeto de pesquisa.

Basicamente, o novo serviço propõe que a cobrança de mensalidades vencidas seja feita em 3 (três) fases. A primeira fase seria realizada pela IESP. Nesta fase, as mensalidades não pagas seriam cobradas pela instituição de ensino através de um processo de cobrança interno por até 90 dias após o vencimento de cada uma das mensalidades.

Decorrido esse prazo, seria iniciada a segunda fase da cobrança. Nesta fase, a instituição de ensino venderia os débitos em aberto para a $\mathrm{CR}$, que passaria a realizar a cobrança dessas mensalidades vencidas como credora até o fim do semestre letivo ou do ano letivo, pois o aluno devedor tem o direito de permanecer estudando até o fim do semestre letivo ou do ano letivo. Então, a cobrança amigável aguardaria o fím do período letivo, haja vista que este é um bom momento de negociação, liberando o aluno devedor para a rematrícula.

Para terminar, iniciar-se-ia a terceira fase da cobrança. Nesta fase, os débitos que permanecessem em aberto após o período de rematrícula seriam cobrados judicialmente pela RAF. Dessa maneira, o ciclo de cobrança todo seria completado, ou seja, realizar a cobrança interna até 90 dias, a cobrança amigável até o fim do período letivo e a cobrança judicial após o fim da rematrícula.

Com o ciclo completo, a totalidade dos alunos seria cobrada, nenhuma mensalidade vencida deixaria de sofrer algum tipo de ação de cobrança e o aluno devedor teria recebido todas as oportunidades legais e administrativas para resolver seu endividamento. 
Tabela 8 - Fases de Cobrança

\begin{tabular}{|c|c|c|c|c|}
\hline $\begin{array}{c}\text { FASE DE } \\
\text { COBRANÇA }\end{array}$ & QUEM & TIPO & PRAZO & CREDOR \\
\hline Primeira fase & IESP & $\begin{array}{c}\text { Cobrança } \\
\text { Interna }\end{array}$ & Até 90 dias & IESP \\
\hline Segunda fase & $\mathrm{CR}$ & $\begin{array}{c}\text { Cobrança } \\
\text { Amigável }\end{array}$ & $\begin{array}{c}\text { Até } 180 \text { dias ou } \\
365 \text { dias }\end{array}$ & CR \\
\hline Terceira fase & RAF & $\begin{array}{c}\text { Cobrança } \\
\text { Judicial }\end{array}$ & $\begin{array}{c}\text { Após o fim do } \\
\text { semestre letivo } \\
\text { ou do ano letivo }\end{array}$ & CR \\
\hline
\end{tabular}

Fonte: $\mathrm{O}$ autor.

A grande vantagem deste novo serviço é o fato de que a instituição de ensino receberá todo o montante devido à vista, sem a necessidade de aguardar que o esforço de cobrança produza os resultados esperados.

Assim, ao invés de a IESP realizar a cobrança por conta própria através de uma equipe interna de cobrança, contratando cobradores e advogados para realizar a cobrança amigável e judicial, o que lhe aumentará os seus custos, ela venderá esses débitos e receberá o valor nominal descontado da taxa à vista.

Por outro lado, vendendo os débitos, a instituição não terá mais que aguardar a negociação e o repasse dos valores negociados. Normalmente, os acordos com os devedores ocorrem mediante o parcelamento dos débitos, pois o devedor, na maioria das vezes, paga sua dívida em parcelas, com prazo médio de 10 parcelas, podendo chegar a 60 meses em alguns casos.

Ademais, não teria que gerenciar o contrato de prestação de serviços de cobrança de uma assessoria de cobrança terceirizada, pois vendendo os débitos após o vencimento a IESP receberia, por exemplo, $40 \%$ do valor nominal à vista, eliminando os controles de encaminhamento, de negociação, de pagamentos, prestações de contas e outros relatórios de controle e auditoria. 
Ressalta-se que se desconhece a existência deste tipo de serviço no mercado, (pesquisas realizadas até dezembro de 2018), ou seja, que o setor bancário ou de factoring comprem recebíveis educacionais vencidos. Assim, acredita-se que este pode ser um serviço inovador e uma solução para o problema da queda de receita da CAMARGO RODRIGUES, tendo em vista que se deixará de cobrar estes débitos como terceirizado das instituições de ensino e passar-se-á a cobrá-los como titular dos débitos, invertendo as posições e estabelecendo um ganha-ganha, uma vez que a IESP poderá reforçar seu caixa e a empresa de cobrança poderá aumentar sua carteira de cobrança.

\section{Pagamento de custas processuais pela RAF}

Em 2014, a empresa fechou com um cliente algo semelhante ao novo serviço que foi desenvolvido no presente estudo, para a realização de cobrança judicial. Naquela época, o cliente externou que não queria mais pagar custas processuais inicias de ajuizamento de mensalidades em aberto nem as taxas de acompanhamento mensais de processo. Diante desse problema apresentado pelo cliente, a RAF propôs assumir esta despesa desde que o honorário advocatício passasse de $20 \%$ para $50 \%$. O cliente negociou e fechou-se em $40 \%$, ou seja, o cliente ficaria com $60 \%$ do valor efetivamente recebido e a RAF ficaria com $40 \%$ do valor à título de cobrir os honorários e reembolso de custas. No fim de 2018, ou seja, 4 anos depois, a RAF tinha recebido somente o valor gasto com custas processuais. Ocorre que, em tese, a expectativa era receber o dobro do valor investido em até 2 anos e, pelo caso concreto, viu-se que o resultado não foi o esperado.

O caso acima ilustra que a precificação da CREV deverá ser feita com muito cuidado, levando em consideração todas as variáveis, pois o valor investido poderá demorar mais tempo para retornar do que o esperado e isso poderá comprometer a saúde financeira da empresa. O quadro abaixo demonstra os serviços prestados atualmente pela CR e pela RAF, colocando por último o novo serviço de CREV. Entretanto, não se registrou nem o custo nem o percentual de êxito, pois o custo será verificado caso a 
caso, com base no modelo de precificação que será apresentado adiante, e o êxito só poderá ser medido após a compra da primeira carteira de recebíveis, o que deverá ocorrer neste ano de 2019.

Tabela 9 - Quadro dos serviços prestados atualmente e o novo serviço

\begin{tabular}{|c|c|c|c|}
\hline & CAMARGO RODRIGUES & RAF ADVOGADOS & NOVO SERVIÇO \\
\hline SERVIÇO & Cobrança amigável & Cobrança judicial & Compra de recebíveis \\
\hline ENVIO & Mensal & Semestral ou anual & Mensal \\
\hline DÉBITOS & $\begin{array}{c}\text { Débitos vencidos a partir de } \\
30 \text { dias }\end{array}$ & $\begin{array}{c}\text { Débitos vencidos a partir } \\
\text { de } 360 \text { dias }\end{array}$ & $\begin{array}{c}\text { Débitos vencidos a } \\
\text { partir de } 90 \text { dias }\end{array}$ \\
\hline CUSTO & Honorários $10 \%$ & Honorários $20 \%$ & Caso a caso \\
\hline ÊXITO & Sucesso $60 \%$ & Sucesso $90 \%$ & A ser medido \\
\hline
\end{tabular}

Fonte: $\mathrm{O}$ autor.

Como se disse acima, para efetuar a compra de recebíveis educacionais vencidos será necessário precificar cada lote de débitos a cada encaminhamento, levando em consideração uma série de variáveis já apontadas, para poder fixar corretamente as taxas de desconto. A data do vencimento da mensalidade atrasada será a informação mais importante de todas.

A seguir, veremos o modelo desenvolvido pelo matemático IVAN FERRAZ, que realizou os cálculos de precificação para um lote de 2014 cobrado pela CR. Este lote de 2014 já completou todo o ciclo de cobrança, ou seja, cobrança interna, amigável e judicial. É um lote que tem começo, meio e fim, e passou por todas as fases de cobrança possíveis.

\section{2- MODELO DE PRECIFICAÇÃO}

O modelo de precificação para compra de recebíveis educacionais vencidos foi feito pelo matemático Ivan Ferraz e visou estimar o valor de uma carteira de recebíveis vencidos do setor educacional usando como base uma carteira de mensalidades de 2014 de uma instituição do ensino superior cliente da CR. 
Tal carteira foi escolhida pois já havia sido aplicado nela o modelo de cobrança completo, ou seja, a cobrança interna realizada pela IESP, a cobrança amigável realizada pela CR até o fim da rematrícula e a cobrança judicial realizada pela RAF após o fim da rematrícula aos alunos que optaram por não negociar seus débitos e, por consequência, optaram por não se rematricular ou eram alunos concluintes, que deixaram o débito em aberto.

\section{3- METODOLOGIA}

O primeiro passo realizado foi analisar o problema utilizando um diagrama de influência para melhor entendimento e mapeamento dos fatores envolvidos na valoração da carteira.

O diagrama de influência é uma ferramenta que permite a estruturação, em um quadro conceptual lógico, de todos os elementos de incerteza envolvidos em determinado problema.

Tal metodologia encontra respaldo em Clemen (1996) e Mcnamee \& Colona (2008).

A seguir, apresenta-se o diagrama de influência adotado:

Figura 15 - Diagrama de influência

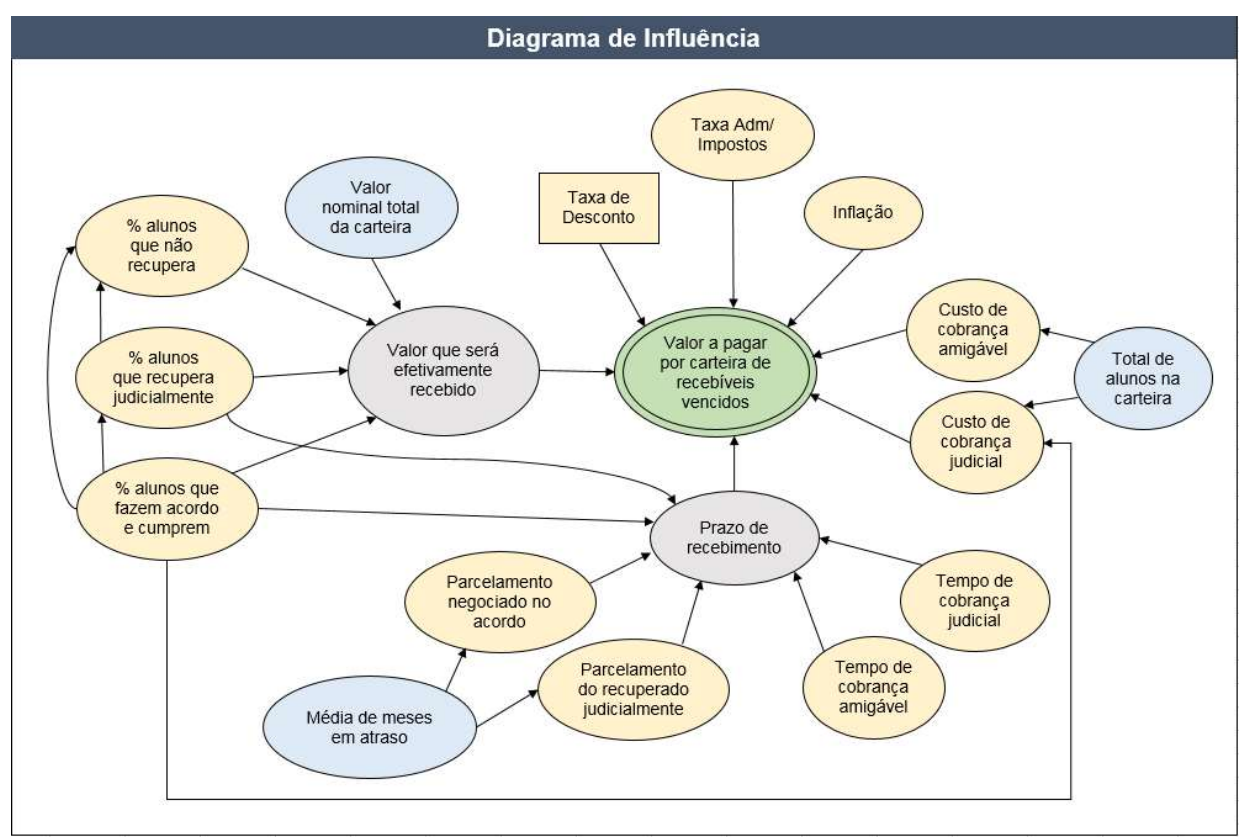

Fonte: Matemático Ivan Ferraz 
Para determinar o valor a pagar por cada carteira, foram levadas em consideração muitas variáveis, como pode ser visto na figura acima. A seguir, serão definidas cada uma delas, iniciando no alto da figura e analisando cada uma no sentido horário:

\subsection{1- NA COR AMARELA:}

1- Taxa de desconto - taxa de variável mensal a ser determinada caso a caso com base na inflação, visando gerar um ganho financeiro.

2- $\quad$ Taxa de administração + impostos - taxa a ser aplicada pela administração da carteira mais os impostos incidentes.

3- Inflação - índice oficial adotado pelo governo - IPCA.

4- Custo de cobrança amigável - é o custo mensal de cada cobrança, levando-se em consideração as despesas do escritório como um todo.

5- Custo de cobrança judicial - é o custo mensal de cada processo, levandose em consideração as despesas do escritório.

6- $\quad$ Tempo de cobrança judicial - é o tempo médio que leva para fechar um acordo judicial parcelado dentro de um processo na justiça.

7- Tempo de cobrança amigável - é o tempo médio que leva para fechar um acordo parcelado de um débito de mensalidade.

8- Parcelamento do recuperado judicialmente - é a quantidade média de parcelas de um acordo judicial.

9- $\quad$ Parcelamento negociado do acordo - é a quantidade média de parcelas de um acordo amigável de mensalidades vencidas. 
10- $\%$ de alunos que fazem o acordo e cumprem - percentual estimado de alunos devedores que fazem acordo amigável e cumprem.

11- \% de alunos dos quais se recuperam valores judicialmente - é a porcentagem média de alunos que são ajuizados e cumprem.

12- $\%$ alunos dos quais não recuperam - porcentagem média de alunos que ficam com os débitos em aberto.

\subsection{2- NA COR AZUL}

1- Total de alunos na carteira - é o número total de devedores enviado mensalmente pelos clientes que têm mensalidades em aberto para serem cobradas amigável ou judicialmente.

2- $\quad$ Média de meses em atraso - é a média de meses que as mensalidades estão em atraso quando é feito o acordo amigável ou judicial.

3- Valor nominal total da carteira - é o valor nominal total da carteira enviada mensalmente pelo cliente credor.

\subsection{3- NA COR VERDE ÁGUA}

1- Prazo de recebimento - é o prazo médio dos acordos amigáveis e judiciais.

2- Valor que será efetivamente recebido - é o valor que será recebido de cada devedor, devidamente corrigido com juros, mora e correção monetária.

\subsection{4- NA COR VERDE}

1- Valor a pagar por carteira de recebíveis - é o valor a ser pago por cada carteira de recebíveis vencidos, levando-se em consideração todas as variáveis acima.

Basicamente, ao se analisar o problema detalhadamente, chegou-se à hipótese de que o valor atual de uma carteira de recebíveis pode ser determinado como um percentual de seu valor nominal, o qual pode ser influenciado por determinadas 
características da carteira, como, por exemplo, o prazo médio das mensalidades vencidas.

O primeiro passo para testar essa hipótese foi determinar o valor de uma carteira com débitos de até 90 dias, para a qual estavam disponíveis informações históricas.

O método escolhido para valoração da carteira foi o Fluxo de Caixa Descontado (FCD). Trata-se de uma metodologia bastante utilizada por bancos de investimento, consultorias, etc., para avaliar empresas e calcular o valor da organização trazendo a valor presente a projeção de seu fluxo de caixa futuro.

Para isso, utilizaram-se os conceitos de Fluxo de Caixa Descontado tratados pelos autores Damodaran (2007, 2009) e Copeland, Koller \& Murrin (2001).

Essa metodologia foi adaptada para o problema em questão. Ao invés de tentar estimar o fluxo de caixa potencial de uma determinada carteira de recebíveis, optou-se por utilizar esse método para calcular o valor de carteiras históricas, das quais o fluxo de caixa real fosse conhecido.

Como os únicos dados históricos disponíveis diziam respeito ao status mensal de um lote de mensalidades vencidas do ano de 2014 e seus respectivos valores, a estratégia adotada foi elaborar premissas que permitissem estimar o fluxo de caixa dessa carteira.

Segue detalhamento desse processo. Exemplo dos dados utilizados:

Tabela 10 - Status de débito

\begin{tabular}{|c|c|c|c|}
\hline \begin{tabular}{|l|} 
VALOR DÉBITOS \\
STATUS DÉBITOS \\
\end{tabular} & \begin{tabular}{|l|l|} 
MESES \\
$2014-01$
\end{tabular} & 2014-02 & 2014-03 \\
\hline ABONADO & $1.506,00$ & 273,82 & \\
\hline ACORDO & $202.893,46$ & $86.613,02$ & $68.221,37$ \\
\hline BAIXADO & $59.854,10$ & $2.404,00$ & 972,00 \\
\hline DÉBITO & $9.118,50$ & & 450,00 \\
\hline \multicolumn{4}{|l|}{ DEVOLVIDO } \\
\hline INAJUIZAVE & $5.504,81$ & & \\
\hline J_SUSPENSO & $1.010,00$ & & \\
\hline JURIDICO & $20.252,47$ & $7.135,01$ & $8.317,94$ \\
\hline NEGOCIADO & $50.444,70$ & & $20.738,42$ \\
\hline Total Geral & $350.584,04$ & $96.425,85$ & $98.699,73$ \\
\hline
\end{tabular}

Fonte: Matemático Ivan Ferraz. 
Dentre os possíveis status das mensalidades, foram considerados como valores não recuperados (não entraram no fluxo de caixa) aqueles classificados como: "Abonado", "Débito", "Devolvido", "Inajuizável" e "J_Suspenso".

Já os débitos classificados como "Acordo" e "Baixado" foram considerados como valores recuperados (receitas no fluxo de caixa) por meio de cobrança amigável.

Por fim, os débitos classificados como "Jurídico" e "Negociado" foram considerados como valores recuperados (receitas no fluxo de caixa) por meio de cobrança judicial.

Os custos (valores negativos no fluxo de caixa), bem como sua alocação no tempo, foram estimados pela própria CAMARGO RODRIGUES.

As premissas iniciais para o cálculo foram as seguintes:

- As receitas mensais, geradas a partir dos dados históricos fornecidos, foram consideradas como receitas líquidas.

- $\quad$ Valores recuperados por "Acordo" ou "Baixado" no mês M entram no fluxo de caixa a partir do mês $\mathrm{M}+4$ em 10 parcelas iguais.

- $\quad$ Valores recuperados por "Jurídico" ou "Negociado" no mês M entram no fluxo de caixa a partir do mês M+18 em 20 parcelas iguais.

- $\quad$ Custo de cobrança amigável igual a $\mathrm{R} \$ 300,00$ por aluno (para 100\% dos alunos da carteira) e dividido em 6 parcelas iguais a partir do mês 1 .

- Custo de cobrança judicial igual a $\mathrm{R} \$ 1.000,00$ por aluno (para 30\% dos alunos da carteira) e dividido em 6 parcelas iguais a partir do mês 7 .

- VPL calculado para mês 0 , considerando-se taxa de desconto de $2 \%$ ao mês, lembre-se que esta taxo poderá variar de $0,5 \%$ a $2 \%$ por mera liberalidade do comprador.

Dessa forma, foi possível gerar o fluxo de caixa da carteira conforme exemplificado na figura abaixo: 


\begin{tabular}{|c|c|c|c|c|c|c|c|c|c|c|c|c|c|c|}
\hline \multirow{3}{*}{$\begin{array}{c}\text { Item } \\
1\end{array}$} & \multirow{3}{*}{$\begin{array}{c}\text { Mês } \\
\text { jan/14 }\end{array}$} & \multicolumn{6}{|c|}{ Receitas } & \multicolumn{7}{|c|}{ Custos } \\
\hline & & \multirow[t]{2}{*}{ Acordo_Baixado } & \multirow{2}{*}{ Juridico_Negociado } & \multicolumn{2}{|c|}{ Total } & \multicolumn{2}{|c|}{ Valor Presente } & \multicolumn{2}{|c|}{ Cobrança_Amigável } & \multirow[t]{2}{*}{ Cobrança_Judicial } & \multicolumn{2}{|c|}{ Total } & \multicolumn{2}{|c|}{ Valor Presente } \\
\hline & & & & $\mathrm{RS}$ & - & $\mathrm{RS}$ & - & $\mathrm{RS}$ & $60.950,00$ & & $\mathrm{RS}$ & $60.950,00$ & $\mathrm{RS}$ & $59.754,90$ \\
\hline 2 & $\mathrm{fev} / 14$ & & & $\mathrm{RS}$ & - & $\mathrm{RS}$ & - & $\mathrm{RS}$ & $60.950,00$ & & $\mathrm{RS}$ & $60.950,00$ & $\mathrm{RS}$ & $58.583,24$ \\
\hline 3 & $\mathrm{mar} / 14$ & & & $R S$ & - & $\mathrm{RS}$ & - & $\mathrm{R} \$$ & $60.950,00$ & & $\mathrm{RS}$ & $60.950,00$ & $\mathrm{RS}$ & $57.434,55$ \\
\hline 4 & $\mathrm{abr} / 14$ & & & RS & - & $\mathrm{RS}$ & - & $\mathrm{RS}$ & $60.950,00$ & & $\mathrm{RS}$ & $60.950,00$ & $\mathrm{RS}$ & $56.308,38$ \\
\hline 5 & $\mathrm{mai} / 14$ & $\begin{array}{|ll|}R & 26.274,76 \\
\end{array}$ & & $\mathrm{RS}$ & $26.274,76$ & $\mathrm{RS}$ & $23.797,86$ & $\mathrm{RS}$ & $60.950,00$ & & $\mathrm{RS}$ & $60.950,00$ & $\mathrm{R} \$$ & $55.204,29$ \\
\hline 6 & jun/14 & $\begin{array}{|ll|}\text { R\$ } & 35.176,46 \\
\end{array}$ & & R\$ & $35.176,46$ & $\mathrm{RS}$ & $31.235,69$ & $\mathrm{RS}$ & $60.950,00$ & & $\mathrm{R} \$$ & $60.950,00$ & $\mathrm{RS}$ & $54.121,86$ \\
\hline 7 & $\mathrm{jul} / 14$ & $\begin{array}{|ll|}\text { RS } & 42.095,80 \\
\end{array}$ & & \begin{tabular}{|l|}
$\mathrm{R} S$ \\
\end{tabular} & $42.095,80$ & $\mathrm{RS}$ & $36.646,92$ & & & $60.950,00$ & $\mathrm{R} \$$ & $60.950,00$ & $\mathrm{RS}$ & $53.060,64$ \\
\hline
\end{tabular}

Figura 16 - Fluxo de caixa dos 7 primeiros meses

Fonte: Matemático Ivan Ferraz.

A fórmula utilizada para trazer as receitas e custos a valor presente é a seguinte:

$$
\text { Valor }=\sum_{t=1}^{t=n} \frac{\mathrm{FC}_{t}}{(1+r)^{t}}
$$

$\mathrm{FC}_{\mathrm{t}}=$ Fluxo de caixa no período $\mathrm{t}$

$\mathrm{r}=$ taxa de desconto (mensal)

$\mathrm{t}=$ período (mês)

$\mathrm{n}=$ total de períodos (meses)

\section{RESULTADO FINAL}

O valor da carteira analisada ficou definido como um \% de seu valor nominal. $O$ resultado do fluxo de caixa descontado aparece no cenário e é o ponto de equilíbrio entre receitas e despesas, considerando uma taxa de retorno sobre o capital; a margem do lucro financeiro ainda deve ser aplicada, o que deve diminuir ainda mais estes percentuais, e os percentuais encontrados não consideram nenhuma margem de segurança, a qual poderia ser de $15 \%$ para mais, num cenário otimista, ou de $\mathbf{1 5 \%}$ para menos, num cenário pessimista. 
Tabela 11: Taxa de retorno sobre o capital

\begin{tabular}{|c|c|}
\hline $\begin{array}{c}\text { TAXA DE RETORNO } \\
\text { SOBRE O CAPITAL }\end{array}$ & $\begin{array}{c}\text { PERCENTUAL DE } \\
\text { PAGAMENTO }\end{array}$ \\
\hline $0,5 \%$ & $73,7 \%$ \\
\hline $1,0 \%$ & $65,5 \%$ \\
\hline $\mathbf{2 , 0} \%$ & $\mathbf{5 1 , 8 \%}$ \\
\hline
\end{tabular}

Fonte: Matemático Ivan Ferraz.

\section{4- VALIDAÇÃO}

A compra de recebíveis educacionais vencidos desenvolvida resume-se basicamente à compra de um lote de mensalidades 90 dias após seu vencimento. Este lote será pago ao cliente à vista - paga-se percentual sobre o valor nominal que será calculado caso a caso levando-se em consideração o tipo de débito, o valor da mensalidade, os custos de cobrança, encargos de cobrança e inadimplência - gerando um novo ciclo de crescimento no serviço de cobrança amigável realizado pela CAMARGO RODRIGUES.

Por meio do estudo feito, concluiu-se que o novo serviço de compra de recebíveis educacionais vencidos atendeu às expectativas dos clientes e poderá auxiliar a CAMARGO RODRIGUES na retomada de seu crescimento, pois será possível oferecer ao cliente um sistema completo de cobrança para o setor educacional, que será composto de três serviços principais e fundamentais:

1- Cobrança amigável;

2- Cobrança judicial;

3- $\quad$ Compra de Recebíveis Educacionais Vencidos - CREV.

Como foi dito anteriormente, os dois maiores clientes da empresa já demonstraram interesse no produto, e duas tentativas de prototipar o serviço foram feitas. Uma primeira tentativa de realizar a operação de compra de recebíveis ocorreu no mês de dezembro de 2018, junto ao Grupo A. Contudo, como se tratava da compra de 
direitos creditórios de uma ação judicial transitada em julgado junto ao Banco Santander, o negócio não se concretizou, pois o risco da operação mostrou-se altíssimo, mesmo pagando-se 50\% do valor nominal, ou seja, conforme o modelo de precificação. Além disso, esta operação acabou sendo descartada também, por não ser objeto da presente pesquisa.

Além dessa operação, foi feita outra tentativa, agora com o Grupo B, mas a operação também não se concretizou porque o cliente queria receber $70 \%$ do valor nominal dos débitos, o que representava uma taxa de remuneração de aproximadamente $0,5 \%$ (vide Tabela 11). Por ser desejada uma taxa de retorno superior, a operação não foi concretizada.

Dessa forma, identificou-se que o percentual a ser pago para à Instituição de Ensino poderá variar conforme a taxa de retorno sobre o capital que se pretender ter. Quanto maior a taxa de retorno (2\%), menor o percentual a ser pago $(51,8 \%)$. Quanto menor a taxa de retorno $(0,5 \%)$, maior o percentual a ser pago $(73,7 \%)$.

Nesse sentido, como exemplo, veja-se o resultado de uma operação concretizada há 4 anos sem um estudo estatístico e financeiro. O produto consistia em assumir o pagamento das custas processuais para ajuizamento, realizando a cobrança judicial de mensalidades em aberto e de acordos rompidos por conta e responsabilidade do escritório, para depois repartir o resultado em $60 / 40,60 \%$ para o cliente e $40 \%$ para a RAF ADVOGADOS, a título de honorários e reembolso das custas processuais. Pela experiência acumulada, a empresa achou que conseguiria receber em 2 anos as custas processuais pagas pelo escritório e ainda parte dos honorários. No entanto, passados 4 anos, só recebeu as despesas incorridas com o pagamento das custas processuais, mas não as relativas às despesas para dar andamento aos processos e os juros do período, que seriam cobertas pelos honorários advocatícios, os quais normalmente são de $20 \%$. Neste caso, cobrou-se $100 \%$ a mais do cliente, ou seja, $40 \%$ no sucesso; mas, em 4 anos conseguiu-se receber somente a importância gasta com as custas processuais, que foi a importância investida inicialmente para dar entrada nos processos, e não se receberam ainda os honorários devidos, pois os valores recebidos até o momento, somando-se custas e honorários, foram inferiores ao que se previu à época. 
Sendo assim, a pesquisa demonstrou a importância de precificar corretamente as carteiras a serem compradas utilizando-se bases históricas, para evitar prejuízos. 


\section{6- CONCLUSÕES E LIMITAÇÕES DA PESQUISA}

Incialmente, se destaca que a Camargo Rodrigues iniciou suas atividades em 1996 e seguiu em oceano azul até meados de 2008 quando foi obrigada a se reinventar pois seus serviços já haviam sido copiados pela concorrência e pelo próprio cliente que graças aos avanços tecnológicos passou a realizar a cobrança internamente.

Nessa reinvenção, constituiu a RAF Advogados que passou a realizar a cobrança judicial das mensalidades vencidas de seus clientes até que em 2016 começou novamente a ser copiada pelos seus concorrentes e por outros escritórios de advocacia que prestavam serviços para instituições de ensino.

Em razão disso, no Mestrado Profissional de empreendedorismo desenvolvemos um novo serviço: a compra de recebíveis vencidos educacionais. A aceitação do novo serviço foi excelente, tanto que os 2 (dois) maiores clientes, mais antigos e mais importantes, reagiram de forma positiva imediatamente. Acredita-se que houve tamanha aceitação pelo fato de que estes clientes sofreram muito nos últimos anos com as altas taxas de evasão e de inadimplência. De fato, quando há uma crise econômica, as instituições de ensino têm dificuldade de cortar custos na mesma velocidade em que a receita cai, porque qualquer número de alunos em sala de aula precisa de um professor. Hoje em dia, o aluno inadimplente prefere desistir do curso a permanecer estudando e gerando dívida.

Concluiu-se também, conforme os estudos realizados em uma carteira de 4 anos (2014/2018), que será possível pagar, no máximo, 51,8\% pelas carteiras a serem compradas, estimando-se taxa de retorno sobre o capital de $2 \%$ ao mês, percentual que pode ser ainda menor dependendo do ganho financeiro que se pretenda ter. Teoricamente, este percentual, de 51,8\%, representa o ponto de equilíbrio da operação, ou seja, não se estaria ganhando nem perdendo. O ideal seria pagar menos de $50 \%$ para carteiras vencidas há mais de 90 dias, gerando assim um ganho financeiro para a empresa.

Entretanto, viu-se também que poderia ser aplicada uma taxa de retorno sobre o capital menor, de $1,0 \%$ e de $0,5 \%$, o que aproximaria o percentual a ser pago àquele 
ofertado pelo cliente $\mathrm{B}$, ora pesquisado, haja vista que os percentuais ficariam em $65,5 \%$ e $73,7 \%$, respectivamente.

Dessa forma, vê-se a importância do presente estudo, pois, como demonstrado, na tentativa de negociação com o Grupo B, o percentual pedido pelo cliente foi de $70 \%$ do valor nominal das mensalidades vencidas. Se fossem pagos $70 \%$ pela carteira do cliente, a empresa estaria recebendo uma taxa de retorno sobre o capital de $0,5 \%$, que seria menor do que o pretendido.

Assim, a pesquisa desenvolvida na experiência do pesquisador no mestrado profissional de empreendedorismo mostrou que os novos produtos e serviços a serem desenvolvidos têm que ser muito bem estudados estatisticamente, orçados, validados e prototipados, para não incorrerem futuramente em prejuízos, o que poderia comprometer a saúde financeira da empresa.

Quanto às limitações encontradas, viu-se que, com referência às análises das carteiras, será necessário um aperfeiçoamento do modelo de avaliação das carteiras a serem compradas, para obtenção de uma precificação ainda mais precisa, com dedicação em tempo integral dos programadores de TI, assim como de matemáticos, para a realização de cálculos que levem em consideração também a situação econômica do momento.

Outra ameaça encontrada foi a disposição do devedor de quitar sua dívida, que pode mudar de uma época para outra e alterar a estimativa de sucesso da carteira.

Além disso, há toda uma análise de documentos dos alunos que serão fundamentais para legalizar a operação, como: contrato de prestação de serviço educacional devidamente assinado pelo aluno, ficha de presença e ficha financeira. Esses documentos são indispensáveis para a realização da cobrança judicial dos débitos em segurança, para que não haja objeções legais.

Diante do exposto, pode-se dizer que o novo serviço desenvolvido pelo autor durante o mestrado tem potencial para ser difundido, contudo há que ter cautela, pois os riscos são altos.

Em tempo, vale destacar um fato identificado em dezembro/2018 e janeiro/2019. Muitos alunos não compareceram para realizar os acordos de suas dívidas para a 
rematrícula de 2019, o que diminuiu sensivelmente as taxas de recuperação, que giravam em torno de 70\% no amigável e 95\% no judicial. Além disso, identificou-se também um aumento na inadimplência de acordos realizados, que era em torno de 5\% em 2014 e passou para algo em torno de 20\% em 2018. Ainda não se conseguiu identificar precisamente as causas disso, mas é incontestável que esse fato aumenta ainda mais o risco do novo serviço, uma vez que as taxas de recuperação podem ficar em níveis que inviabilizem o novo serviço de compra de recebíveis.

Em suma, a empresa está avaliando com bastante cautela este novo produto, para que não venha a ter problemas futuros. $\mathrm{O}$ estudo demonstrou que este mercado é muito volátil e sensível a mudanças econômicas. Assim, é muito importante que a economia volte a crescer, para que os devedores se sintam seguros o suficiente para negociar suas dívidas, pois realmente não é possível exigir que o aluno devedor assuma um compromisso sem a devida contrapartida do salário para poder honrá-lo.

Futuramente, como o produto Compra de Recebíveis Educacionais Vencidos é regulamentado por lei, poderá dar margem a uma nova atividade financeira. Todavia, para a realização desta atividade será necessária a abertura de uma nova empresa. Nessa perspectiva, recentemente, em 24/04/2019, foi promulgada a LC 167, dispondo sobre a ESC - Empresa Simples de Crédito e alterando a lei de Lavagem de Dinheiro e a Lei do Simples Nacional. Esta nova empresa poderá realizar operações de empréstimo, de financiamento e de desconto de títulos de crédito, exclusivamente com recursos próprios.

Finalmente, conclui-se que a retomada do crescimento da CAMARGO RODRIGUES depende de ela se manter em movimento, criando novos serviços, aperfeiçoando os já existentes, trazendo pessoas competentes para seus quadros, atualizando-se tecnologicamente e adaptando-se constantemente ao novo.

Como diz o professor Martinho I. R de Almeida: "Precisamos estar sempre olhando para a empresa para ver o que pode ser feito". 


\section{7- REFERÊNCIAS BIBLIOGRÁFICAS}

ADIZES, Ichak. Os ciclos de vida das organizações: como e por que as empresas crescem e morrem e o que fazer a respeito. São Paulo: Pioneira, 1993.

ALMEIDA, Martinho Isnard Ribeiro de. Manual de planejamento estratégico: desenvolvimento de um plano estratégico com a utilização de planilhas Excel. São Paulo: Editora Atlas, 2010.

; FRANCESCONI, Milton; FERNANDES, Priscila Pereira. Manual para desenvolvimento de pesquisa profissional: métodos para trabalhos práticos e aplicados. São Paulo: Atlas, 2019.

ANDRADE, Daniela Meirelles et al. Ciclo de vida, competição e estratégias em pequenas e microempresas. REAd - Revista Eletrônica de Administração, Porto Alegre, v. 10, n. 3, ed. 39, maio-jun. 2004.

ANSELMO, Estevão. Mudanças estratégicas nas empresas: um estudo de caso. Dissertação (Mestrado em Administração) - Departamento de Administração da FEAUSP, São Paulo, 1995.

BROWN, Tim. Desing thinking: uma metodologia poderosa para decretar o fim das velhas ideias. Rio de Janeiro: Elsevier, 2010.

CLEMEN, R. T. Making Hard Decisions: An Introduction to Decision Analysis. 2. ed. Duxbury Press, USA, 1996.

COLlinS, James C. Feitas para durar: práticas bem-sucedidas de empresas visionárias. Rio de Janeiro: Rocco, 1995.

COPELAND, T.; KOLLER, T.; MURRIN, J. Avaliação de Empresas: Valuation Calculando e Gerenciando o Valor das Empresas. São Paulo: Pearson Makron Books, 2001.

COSTA, Benny Kramer; ALMEIDA, Martinho Isnard Ribeiro de. Estratégia: perspectivas e aplicações. São Paulo: Atlas, 2002. 
COVEY, Stephen R. O poder da confiança: o elemento que faz toda a diferença. São Paulo: Franklin Covey, Campus/Elsevier, 2008.

DAMODARAN, Aswath. Avaliação de Empresas. 2. ed. São Paulo: Pearson Prentice Hall, 2007.

DAMODARAN, Aswath. The Dark Side of Valuation. Financial Times/Prentice Hall, 2009.

ELLIOTT, J. La investigación-acción en educación. 3. ed. Madrid: Morata, 1997.

FISCHMANN, Adalberto; ALMEIDA, Martinho Isnard Ribeiro de. Planejamento estratégico na prática: Desmistificando a prática do Planejamento Estratégico nas organizações. São Paulo: Atlas, 2018.

FRANCESCONI, Milton. Centro de serviços compartilhados para pequenas empresas: avaliação de uma iniciativa empreendedora de prestação de serviços. Dissertação (Mestrado em Administração) - Departamento de Administração da FEAUSP, São Paulo, 2016.

GASSMAN, Oliver; FRANKERBERGER, Karolin; CSIK, Michaela. O navegador de modelos de negócio: 55 modelos que revolucionarão seu negócio. Rio de Janeiro: Alta Books, 2016.

KIM, W. Chan. A estratégia do oceano azul: como criar novos mercados e tornar a concorrência irrelevante. Rio de Janeiro: Elsevier, 2005.

MCNAMEE, Peter; CELONA, John. Decision Analysis for the professional. 4. ed. Smartorg Inc., USA, 2008.

MINTZBERG, Henry. Safari de estratégia: um roteiro pela selva do planejamento estratégico. Porto Alegre: Bookman, 2010.

MORITZ, Gilberto Oliveira et al. A inadimplência nas instituições de ensino superior: um estudo de caso da instituição XZX. In: COLÓQUIO INTERNACIONAL SOBRE GESTÃO UNIVERSITÁRIA NA AMÉRICA DO SUL, 11., 2011, Florianópolis. CONGRESSO INTERNACIONAL IGLU, 2., 2011, Florianópolis. Anais. Florianópolis: Centro IGLU, 2011. 
OHNO, Taiichi. O sistema Toyota de produção: além da produção em larga escala. Porto Alegre: Bookman, 1997.

OSTERWALDER, Alexander. Business Model Generation: Inovação em Modelos de Negócios. Um manual para visionários, inovadores e revolucionários. Rio de Janeiro: Alta Books, 2011.

PORTER, Michael Eugene. Estratégia Competitiva: técnicas para análise de indústrias e da concorrência. Rio de Janeiro: Elsevier, 2004.

. Vantagem competitiva: criando e sustentando um desempenho superior. Rio de Janeiro: Elsevier, 1989.

RODRIGUES, Luis Fernando O. Gestão da inadimplência educacional. São Paulo: Alabama, 2004.

SCHWAB, Klaus. A quarta revolução industrial. São Paulo: Edipro, 2016.

SHEPHERD, Dean. Empreendedorismo. Porto Alegre: Bookman, 2014.

YIN, Robert K. Estudo de caso: planejamento e métodos. Porto Alegre: Bookman, 2005 . 


\section{8- BIBLIOGRAFIA COMPLEMENTAR}

BRASIL. Constituição da República Federativa do Brasil (CF/88). Coordenação Maurício Antonio Ribeiro Lopes. São Paulo: Editora Revista dos Tribunais, 1996.

BRASIL. Novo Código Civil Brasileiro. Lei 10.406, de 10 de janeiro de 2002. São Paulo: Editora Revista dos Tribunais, 2003.

CLEMEN, R.T. Making Hard Decisions: An Introduction to Decision Analysis. 2 ed. Duxbury Press, USA, 1996.

FLICK, Uwe. Uma introdução à pesquisa qualitativa. Porto Alegre: Bookman, 2007.

GIL, Antonio Carlos. Como elaborar projetos de pesquisa. São Paulo: Atlas, 1987.

GONÇALVES, Elisa Pereira. Iniciação à pesquisa científica. Campinas: Alinea, 2007.

GRESSLER, Lori Alice. Introdução à pesquisa: projetos e relatórios. São Paulo: Loyola, 2003.

HAIR, Joseph Jr. et al. Fundamentos de métodos de pesquisa em Administração. Porto Alegre: Bookman, 2005.

Lei 9870/99- Dispõe sobre o valor total das anuidades escolares e dá outras providências.

MCNAMEE, Peter; CELONA, John. Decision Analysis for the Professional. 4 ed. Smartorg Inc, USA, 2008.

MARCONI, Marina de Andrade; LAKATOS, Eva Maria. Fundamentos de metodologia científica. São Paulo: Atlas, 2010.

RODRIGUES, Luis Fernando $O$. Como reduzir a inadimplência em estabelecimentos de ensino. São Paulo: Alabama, 2001.

TRIPP, David. Pesquisa-ação: uma introdução metodológica. (http://scielo.br)

VERGARA, Sylvia Constant. Métodos de pesquisa em Administração. São Paulo: Atlas, 2008.

WALLIMAN, Nicholas. Métodos de pesquisa. São Paulo: Saraiva, 2015. 


\section{9- ANEXOS}

\section{ANEXO 1}

\section{PREMISSAS INICIAIS PARA CÁLCULO DO FLUXO DE CAIXA}

(PARÂMETROS EM VERMELHO PODEM SER ALTERADOS NAS RESPECTIVAS CÉLULAS)

As receitas mensais, geradas a partir dos dados históricos fornecidos, são consideradas como receitas líquidas.

- Valores recuperados por "Acordo" ou "Baixado" no mês M entram no fluxo de caixa a partir do mês $M+4$, em 10 parcelas iguais.

- Valores recuperados por "Jurídico" ou "Negociado" no mês $M$ entram no fluxo de caixa a partir do mês $M+18$, em 20 parcelas iguais.

- Custo de cobrança amigável igual a $\mathbf{R} \$ \mathbf{3 0 0 , 0 0}$ por aluno (para $100 \%$ dos alunos da carteira) e dividido em 6 parcelas iguais a partir do mês 1.

- Custo de cobrança judicial igual a $\mathbf{R} \mathbf{\$} 1.000,00$ por aluno (para $30 \%$ dos alunos da carteira) e dividido em 6 parcelas iguais a partir do mês 7 .

- VPL calculado para mês 0 , considerando taxa de desconto de $2 \%$ ao mês e intervalo de segurança de $15 \%$ para elaboração de cenários. 


\section{ANEXO 2}

\begin{tabular}{|c|c|c|c|c|}
\hline \multicolumn{5}{|c|}{ Valores históricos de mensalidades em aberto } \\
\hline \multirow{2}{*}{ Mês } & \multicolumn{4}{|c|}{ Status do débito } \\
\hline & \multicolumn{2}{|c|}{ Acordo_Negociado } & \multicolumn{2}{|c|}{ Juridico_Negociado } \\
\hline $2014-01$ & $\mathrm{R} \$$ & $262.747,56$ & $\mathrm{R} \$$ & $70.697,17$ \\
\hline $2014-02$ & $\mathrm{R} \$$ & $89.017,02$ & $\mathrm{R} \$$ & $7.135,01$ \\
\hline $2014-03$ & $\mathrm{R} \$$ & $69.193,37$ & $\mathrm{R} \$$ & $29.056,36$ \\
\hline $2014-04$ & $\mathrm{R} \$$ & $29.352,56$ & $\mathrm{R} \$$ & $45.837,33$ \\
\hline $2014-05$ & $\mathrm{R} \$$ & $128.748,88$ & $\mathrm{R} \$$ & $47.291,06$ \\
\hline $2014-06$ & $\mathrm{R} \$$ & $74.445,81$ & $\mathrm{R} \$$ & $11.781,42$ \\
\hline $2014-07$ & $\mathrm{R} \$$ & $36.063,85$ & $\mathrm{R} \$$ & $67.176,25$ \\
\hline $2014-08$ & $\mathrm{R} \$$ & $1.330 .178,12$ & $\mathrm{R} \$$ & $475.329,58$ \\
\hline 2014-09 & $\mathrm{R} \$$ & $287.064,45$ & $\mathrm{R} \$$ & $117.977,85$ \\
\hline 2014-10 & $\mathrm{R} \$$ & $317.801,93$ & $\mathrm{R} \$$ & $85.221,39$ \\
\hline $2014-11$ & $\mathrm{R} \$$ & $337.288,09$ & $\mathrm{RS}$ & $91.937,50$ \\
\hline $2014-12$ & $\mathrm{R} \$$ & $553.776,24$ & $\mathrm{R} \$$ & $183.501,04$ \\
\hline
\end{tabular}

\begin{tabular}{|c|c|c|}
\hline \multicolumn{2}{|c|}{ Total Nominal } & \multirow{2}{*}{$\begin{array}{c}\text { \% Recuperado } \\
98,4 \%\end{array}$} \\
\hline & $4.827 .679,29$ & \\
\hline
\end{tabular}

\begin{tabular}{|c|}
\hline Taxa de Desconto (\% ao mês) \\
\hline $2,00 \%$ \\
\hline
\end{tabular}

\begin{tabular}{|c|c|c|}
\hline \multicolumn{3}{|c|}{ Alunos na Carteira } \\
\hline Total & 1.219 & $100 \%$ \\
\hline Acordo Negociado & 853 & $70 \%$ \\
\hline Jurídico_Negociado & 366 & $30 \%$ \\
\hline
\end{tabular}




\section{ANEXO 3}

\begin{tabular}{|l|cc|}
\hline \multicolumn{2}{|c|}{ Valor Presente } \\
\hline Receitas & R\$ & $3.147 .460,18$ \\
\hline Custos & & \\
& R\$ & $644.567,05$ \\
\hline
\end{tabular}

Intervalo de segurança:

$15 \%$

\begin{tabular}{|c|c|c|c|}
\hline Cenário & \multicolumn{2}{|c|}{ Valor da Carteira no mês 0} & $\begin{array}{c}\% \text { do Valor } \\
\text { Nominal }\end{array}$ \\
\hline Pessimista & $\mathrm{RS}$ & $2.127 .459,16$ & $44,1 \%$ \\
\hline Realista & $\mathrm{R} \$$ & $2.502 .893,13$ & $51,8 \%$ \\
\hline Otimista & $\mathrm{RS}$ & $2.878 .327,10$ & $59,6 \%$ \\
\hline
\end{tabular}

\begin{tabular}{|c|c|c|c|c|c|}
\hline \multicolumn{7}{|c|}{ Custos } \\
\hline & Unitário & Total & Parcelas & Valor Parcela & $\begin{array}{c}\text { A partir } \\
\text { do mês }\end{array}$ \\
\hline Cobrança Amigável & $\begin{array}{c}\mathrm{R} \$ \\
300,00\end{array}$ & $\begin{array}{c}\mathrm{R} \$ \\
365.700,00\end{array}$ & 6 & $\begin{array}{c}\mathrm{R} \$ \\
60.950,00\end{array}$ & 1 \\
\hline Cobrança Judicial & $\begin{array}{c}\mathrm{R} \$ \\
1.000,00\end{array}$ & $\begin{array}{c}\mathrm{R} \$ \\
365.700,00\end{array}$ & 6 & $\begin{array}{c}\mathrm{R} \$ \\
60.950,00\end{array}$ & 7 \\
\hline
\end{tabular}




\section{ANEXO 4}

\begin{tabular}{|c|c|c|c|c|c|c|c|c|c|c|c|c|c|c|c|}
\hline \multirow{3}{*}{$\begin{array}{c}\text { Item } \\
1 \\
\end{array}$} & \multirow{3}{*}{$\begin{array}{c}\text { Mês } \\
\mathrm{jan} / 14 \\
\end{array}$} & \multicolumn{7}{|c|}{ Receitas } & \multicolumn{7}{|c|}{ Custos } \\
\hline & & Acordo_Baixado & \multicolumn{2}{|c|}{ Juridico_Negociado } & \multicolumn{2}{|r|}{ Total } & \multicolumn{2}{|c|}{ ValorPresente } & \multicolumn{2}{|c|}{ Cobrança_Amigável } & Cobrança Jucicial & \multicolumn{2}{|c|}{ Total } & \multicolumn{2}{|c|}{ Valor Presente } \\
\hline & & & & & $\mathrm{RS}$ & - & $\mathrm{RS}$ & - & $\mathrm{RS}$ & $60.950,00$ & & $\mathrm{RS}$ & $60.950,00$ & $\mathrm{RS}$ & $59.754,90$ \\
\hline 2 & $\mathrm{fev} / 14$ & & & & $\mathrm{RS}$ & - & $\mathrm{RS}$ & - & $\mathrm{RS}$ & $60.950,00$ & & $\mathrm{RS}$ & $60.950,00$ & $\mathrm{RS}$ & 58583,24 \\
\hline 3 & $\mathrm{mar} / 14$ & & & & $\mathrm{RS}$ & - & $\mathrm{RS}$ & - & $\mathrm{RS}$ & $60.950,00$ & & $\mathrm{RS}$ & $60.950,00$ & $\mathrm{RS}$ & $57.434,55$ \\
\hline 4 & $a b r / 14$ & & & & $\mathrm{RS}$ & - & $\mathrm{RS}$ & - & $\mathrm{RS}$ & $60.950,00$ & & $\mathrm{RS}$ & $60.950,00$ & $\mathrm{RS}$ & $56,308,38$ \\
\hline 5 & $\mathrm{mai} / 14$ & $\mathrm{R} \$ \quad 26274,76$ & & & $\mathrm{RS}$ & $26.274,76$ & $\mathrm{RS}$ & $23.797,86$ & $\mathrm{RS}$ & $60.950,00$ & & $\mathrm{RS}$ & $60.950,00$ & $\mathrm{RS}$ & $55.204,29$ \\
\hline 6 & $\mathrm{jun} / 14$ & $\mathrm{R} \$ \quad 35.176,46$ & & & $\mathrm{R} S$ & $35.176,46$ & $\mathrm{RS}$ & 31235,69 & $\mathrm{RS}$ & $60.950,00$ & & $\mathrm{RS}$ & $60.950,00$ & $\mathrm{RS}$ & $54.121,86$ \\
\hline 7 & $\mathrm{jul} / 14$ & $\mathrm{R} \$ \quad 42095,80$ & & & $\mathrm{RS}$ & 42095,80 & $R S$ & $36,646,92$ & & & $\mathrm{R} S \quad 60.950,00$ & $\mathrm{RS}$ & $60.950,00$ & $\mathrm{RS}$ & $53.060,64$ \\
\hline 8 & ago/14 & $\mathrm{R} \$ \quad 45.081,05$ & & & $\mathrm{R} S$ & $45.031,05$ & $\mathrm{RS}$ & $38.433,57$ & & & $\mathrm{R} \$ \quad 60.950,00$ & $\mathrm{R} \$$ & $60.950,00$ & $\mathrm{RS}$ & 52020,24 \\
\hline 9 & set/14 & $\begin{array}{ll}\mathrm{R} S \quad 57.905,94 \\
\end{array}$ & & & $\mathrm{R} S$ & $57.905,94$ & $\mathrm{RS}$ & $48.453,10$ & & & $\begin{array}{|ll|}\mathrm{R} S & 60.950,00 \\
\end{array}$ & $\mathrm{RS}$ & $60.950,00$ & $\mathrm{RS}$ & 5100,23 \\
\hline 10 & out $/ 14$ & $\mathrm{R} \$ \quad 65.350,52$ & & & $\mathrm{R} S$ & $65.350,52$ & $\mathrm{RS}$ & $53.610,19$ & & & $\mathrm{R} \$ \quad 60.950,00$ & $\mathrm{RS}$ & $60.950,00$ & $\mathrm{RS}$ & $50.000,23$ \\
\hline 11 & nov/14 & $\mathrm{R} S \quad 68956,91$ & & & $\mathrm{RS}$ & 68956,91 & $\mathrm{RS}$ & $55.459,49$ & & & $\begin{array}{ll}S & 60.950,00 \\
\end{array}$ & RS & $60.950,00$ & $\mathrm{RS}$ & $49.019,83$ \\
\hline 12 & $\mathrm{dez} / 14$ & RS $\quad 201974,72$ & & & $\mathrm{RS}$ & 201974,72 & $\mathrm{RSS}$ & $159.255,69$ & & & $\mathrm{R} S \quad 60.950,00$ & $\mathrm{RS}$ & $60.950,00$ & $\mathrm{RS}$ & 48058,66 \\
\hline 13 & $\mathrm{jan} / 15$ & RS' 230681,16 & & & $\mathrm{R} S$ & $230.681,16$ & $\mathrm{RS}$ & $178.324,04$ & & & & $\mathrm{RS}$ & - & $R S$ & - \\
\hline 14 & $\mathrm{fev} / 15$ & RS 262461,36 & & & $\mathrm{RS}$ & 262461,36 & $R S$ & $198.912,91$ & & & & $\mathrm{RS}$ & - & $R S$ & - \\
\hline 15 & $\mathrm{mar} / 15$ & RS' $269.915,41$ & & & $\mathrm{RS}$ & $269.915,41$ & $\mathrm{RS}$ & $200.551,12$ & & & & $\mathrm{R} S$ & - & $\mathrm{RS}$ & - \\
\hline 16 & $a b r / 15$ & RS' 316391,33 & & & $\mathrm{R} S$ & $316.391,33$ & $\mathrm{RS}$ & $230.473,94$ & & & & $\mathrm{R} S$ & - & $R S$ & - \\
\hline 17 & $\mathrm{mai} / 15$ & RS' $309.471,99$ & & & $\mathrm{RS}$ & $309.471,99$ & $R S$ & 221013,31 & & & & $\mathrm{RS}$ & - & $R S$ & - \\
\hline 18 & jun/15 & RS 306536,74 & & & $\mathrm{R} S$ & $306.536,74$ & $\mathrm{RS}$ & $214.624,57$ & & & & $\mathrm{R} S$ & - & $R S$ & - \\
\hline 19 & $\mathrm{jul} / 15$ & RS' $293.661,85$ & $\mathrm{RS}$ & $3.534,86$ & $\mathrm{RS}$ & 297.196,71 & $\mathrm{RSS}$ & $204.004,96$ & & & & $\mathrm{RS}$ & - & $\mathrm{RS}$ & - \\
\hline 20 & $\mathrm{ago} / 15$ & $\mathrm{RS} \quad 286,217,27$ & $\mathrm{RS}$ & $3.891,61$ & $\mathrm{R} S$ & $290.108,88$ & $\mathrm{RSS}$ & $195.234,96$ & & & & $\mathrm{R} \$$ & - & $\mathrm{RSS}$ & - \\
\hline 21 & set/15 & RS' 282610,88 & $\mathrm{RSS}$ & $5.344,43$ & $\mathrm{RS}$ & $287.955,31$ & $\mathrm{RS}$ & $189.985,95$ & & & & $\mathrm{R} S$ & - & $\mathrm{RS}$ & - \\
\hline 22 & out/15 & $\mathrm{R} S \quad 149.593,07$ & $\mathrm{R} \$$ & $7.636,29$ & $\mathrm{R} S$ & $157.229,36$ & $\mathrm{RSS}$ & 101702,09 & & & & $\mathrm{R} S$ & - & $R S$ & - \\
\hline 23 & nov/15 & R's 120886,63 & $\mathrm{RS}$ & $10.000,85$ & $\mathrm{RS}$ & $130.887,47$ & RS & $83.003,07$ & & & & $\mathrm{RS}$ & - & $\mathrm{RS}$ & - \\
\hline 24 & $\mathrm{dez} / 15$ & RS $89.106,43$ & $\mathrm{RS}$ & $10.589,92$ & $\mathrm{RS}$ & $99.696,35$ & $\mathrm{RS}$ & 61983,36 & & & & $\mathrm{RS}$ & - & $R S$ & - \\
\hline 25 & $\mathrm{jan} / 16$ & $\mathrm{R} S \quad 55.377,62$ & $\mathrm{RS}$ & $13.948,73$ & $\mathrm{RS}$ & $69.326,35$ & $\mathrm{RS}$ & 42256,55 & & & & $\mathrm{RS}$ & - & $\mathrm{RS}$ & - \\
\hline 26 & $\mathrm{fev} / 16$ & & $\mathrm{RS}$ & $37.715,21$ & $\mathrm{RS}$ & $37.715,21$ & $\mathrm{RS}$ & 22537,83 & & & & $\mathrm{R} S$ & - & $\mathrm{RS}$ & - \\
\hline 27 & $\mathrm{mar} / 16$ & & $\mathrm{RS}$ & $43.614,10$ & $\mathrm{RS}$ & $43.614,10$ & $\mathrm{RS}$ & $25.551,85$ & & & & $\mathrm{RS}$ & - & $R S$ & - \\
\hline 28 & $\mathrm{abr} / 16$ & & $\mathrm{RS}$ & $47.875,17$ & $\mathrm{RS}$ & $47.875,17$ & $\mathrm{RS}$ & $27.498,28$ & & & & $\mathrm{RS}$ & - & $\mathrm{RS}$ & - \\
\hline 29 & $\mathrm{mai} / 16$ & & $\mathrm{RS}$ & 52472,05 & $\mathrm{RS}$ & 52472,05 & $\mathrm{RS}$ & $29.547,65$ & & & & $\mathrm{R} S$ & - & $\mathrm{RS}$ & - \\
\hline 30 & $\mathrm{jun} / 16$ & & $\mathrm{RS}$ & 61647,10 & $\mathrm{R} S$ & 61647,10 & $\mathrm{RSS}$ & $34.033,57$ & & & & $\mathrm{R} S$ & - & $R S$ & - \\
\hline 31 & $\mathrm{jul} / 16$ & & $\mathrm{RS}$ & 61647,10 & $\mathrm{RS}$ & 61647,10 & $\mathrm{RS}$ & $33.366,24$ & & & & $\mathrm{RS}$ & - & $\mathrm{RS}$ & - \\
\hline 32 & ago/16 & & $\mathrm{RS}$ & 61647,10 & $\mathrm{R} S$ & 61647,10 & $\mathrm{RSS}$ & 32712,00 & & & & $\mathrm{R} S$ & - & $\mathrm{RS}$ & - \\
\hline 33 & set/16 & & $\mathrm{RS}$ & 61647,10 & $\mathrm{R} S$ & 61647,10 & $\mathrm{RS}$ & 32070,59 & & & & $\mathrm{R} S$ & - & $R S$ & - \\
\hline 34 & out/16 & & $\mathrm{RS}$ & 61647,10 & $\mathrm{RS}$ & $61,647,10$ & $\mathrm{RS}$ & 31441,76 & & & & $\mathrm{RS}$ & - & $R S$ & - \\
\hline 35 & nov/16 & & $\mathrm{RS}$ & 61647,10 & $\mathrm{RS}$ & 61647,10 & $\mathrm{RSS}$ & $30.825,25$ & & & & $\mathrm{R} S$ & - & $\mathrm{RS}$ & - \\
\hline 36 & $\mathrm{dez} / 16$ & & $\mathrm{RS}$ & 61647,10 & $\mathrm{RS}$ & $61,647,10$ & $\mathrm{RS}$ & $30.220,83$ & & & & $\mathrm{RS}$ & - & $R S$ & - \\
\hline 37 & $\mathrm{jan} / 17$ & & $\mathrm{RS}$ & 61647,10 & $\mathrm{RS}$ & $61,647,10$ & $\mathrm{RS}$ & $29.628,27$ & & & & $\mathrm{RS}$ & - & $R S$ & - \\
\hline 38 & $\mathrm{fev} / 17$ & & $\mathrm{RS}$ & 61647,10 & $\mathrm{RS}$ & 61647,10 & $\mathrm{RS}$ & $29.047,32$ & & & & $\mathrm{RS}$ & - & $\mathrm{RS}$ & - \\
\hline 39 & $\mathrm{mar} / 17$ & & $\mathrm{RS}$ & 58112,24 & $\mathrm{RS}$ & $58.112,24$ & $\mathrm{RS}$ & $26.844,85$ & & & & $\mathrm{RS}$ & - & $\mathrm{RS}$ & - \\
\hline 40 & $\mathrm{abr} / 17$ & & $\mathrm{RS}$ & $57.755,49$ & $\mathrm{RS}$ & $57.755,49$ & RS & $26.156,91$ & & & & $\mathrm{RS}$ & - & $\mathrm{RS}$ & - \\
\hline 41 & $\mathrm{mai} / 17$ & & $\mathrm{RS}$ & $56,302,6$ & $\mathrm{RS}$ & $56.302,6$ & $\mathrm{RS}$ & $24.998,96$ & & & & $\mathrm{RS}$ & - & $\mathrm{RS}$ & - \\
\hline 42 & $\mathrm{jun} / 17$ & & $\mathrm{RS}$ & $54.010,80$ & $\mathrm{RS}$ & $54.010,80$ & $\mathrm{RS}$ & $23.511,13$ & & & & $\mathrm{R} \$$ & - & $\mathrm{RS}$ & - \\
\hline 43 & $\mathrm{jul} / 17$ & & $\mathrm{RS}$ & 51646,25 & $\mathrm{RS}$ & $51,646,25$ & $\mathrm{RS}$ & 22041,01 & & & & $\mathrm{RS}$ & - & $R S$ & - \\
\hline 44 & ago/17 & & $\mathrm{RS}$ & 51057,18 & $\mathrm{RS}$ & 51057,18 & $\mathrm{RS}$ & 21362,36 & & & & $\mathrm{RS}$ & - & $\mathrm{RS}$ & - \\
\hline 45 & set/17 & & $\mathrm{RS}$ & $47.698,37$ & $\mathrm{RS}$ & $47.698,37$ & $\mathrm{RS}$ & $19.565,72$ & & & & $\mathrm{RS}$ & - & $\mathrm{RS}$ & - \\
\hline 46 & out/17 & & $\mathrm{RS}$ & $23.931,89$ & $\mathrm{RS}$ & $23.931,89$ & $\mathrm{RS}$ & $9.624,30$ & & & & $\mathrm{R} S$ & - & $\mathrm{RS}$ & - \\
\hline 47 & nov/17 & & $\mathrm{RS}$ & 18033,00 & $\mathrm{R} S$ & $18.033,00$ & $\mathrm{RS}$ & $7.109,84$ & & & & $\mathrm{R} S$ & - & $\mathrm{RS}$ & - \\
\hline 48 & dez/17 & & $\mathrm{RS}$ & $13.77,93$ & $\mathrm{RS}$ & $13.71,93$ & $\mathrm{RS}$ & $5.323,37$ & & & & $\mathrm{RS}$ & - & $\mathrm{RS}$ & - \\
\hline 49 & $\mathrm{jan} / 18$ & & $\mathrm{RS}$ & $9.175,05$ & $\mathrm{RS}$ & $9.175,05$ & $\mathrm{RS}$ & $3.476,96$ & & & & $R S$ & - & $\mathrm{RS}$ & - \\
\hline
\end{tabular}




\section{ANEXO 5 \\ MINUTA DO CONTRATO \\ CONTRATO DE CESSÃO DE CRÉDITO EDUCACIONAL}

Pelo presente instrumento, de um lado, como

CEDENTE: (Nome da Cedente), com sede em ( $\mathrm{xxx}$ ), na Rua (xxx), $\mathrm{n}^{\mathrm{o}}(\mathrm{xxx})$, bairro $(\mathrm{xxx})$, CEP ( $\mathrm{xxx})$, no Estado ( $\mathrm{xxx}$ ), inscrita no CNPJ/MF. sob o $\mathrm{n}^{\mathrm{o}}(\mathrm{xxx})$, neste ato representada por seu representante legal (xxx), (Nacionalidade), (Estado Civil), (Profissão), Carteira de Identidade $\mathrm{n}^{\mathrm{o}}(\mathrm{xxx})$, C.P.F. $\mathrm{n}^{\mathrm{o}}$ (xxx), residente e domiciliado na Rua $(\mathrm{xxx}), \mathrm{n}^{\mathrm{o}}(\mathrm{xxx})$, bairro $(\mathrm{xxx})$, CEP ( $\left.\mathrm{xxx}\right)$, Cidade ( $\left.\mathrm{xxx}\right)$, no Estado ( $\mathrm{xxx}$ );

E de outro, como

CESSIONÁRIA: (Nome da Cessionária), com sede em (xxx), na Avenida (xxx), $\mathrm{n}^{\circ}$ ( $\mathrm{xxx}$ ), bairro (xxx), CEP ( $\mathrm{xxx}$ ), no Estado ( $\mathrm{xxx}$ ), inscrita no CNPJ/MF. sob o $\mathrm{n}^{\mathrm{o}}(\mathrm{xxx})$, neste ato representada pelo seu representante legal (xxx), (Nacionalidade), (Estado Civil), (Profissão), Carteira de Identidade $\mathrm{n}^{\mathrm{o}}(\mathrm{xxx})$, C.P.F. $\mathrm{n}^{\mathrm{o}}(\mathrm{xxx})$, residente $\mathrm{e}$ domiciliado na Rua (xxx), $\mathrm{n}^{\mathrm{o}}(\mathrm{xxx})$, bairro (xxx), CEP ( $\mathrm{xxx}$ ), Cidade (xxx), no Estado $(\mathrm{xxx})$.

As partes acima qualificadas têm, entre si, justo e acertado, o presente Contrato de Cessão de Crédito Educacional, que se regerá pelas cláusulas seguintes e condições a seguir aduzidas: 


\section{DO OBJETO}

Cláusula $1^{\text {a }}$. O presente contrato tem como OBJETO o crédito decorrente de contrato de prestação de serviços educacionais firmado entre a CEDENTE e seus contratantes.

\section{DO CRÉDITO}

Cláusula $2^{\mathrm{a}}$. O crédito mencionado acima se configura no valor total de $\mathrm{R} \$(\mathrm{xxx})$ (Valor Expresso), conforme relatório anexo a este instrumento, que será pago pela CESSIONÁRIA mediante TED (transferência bancária).

Cláusula $3^{\text {a }}$. O referido contrato deu origem ao crédito e, consequentemente, à obrigação decorrente deste. Assim, como não houve a entrega do produto, a CESSIONÁRIA se obriga a retirá-lo do depósito da CEDENTE, por sua conta e risco, e entregá-lo diretamente no endereço da Devedora, desde que adimplido com respectivo crédito.

\section{DA CESSÃO}

Cláusula 4a A CEDENTE neste ato declara expressamente ter recebido da CESSIONÁRIA o valor referente ao crédito citado, recebendo-o em moeda corrente e dinheiro, dando a mais ampla e irrevogável quitação, para que não reclame em nenhum tempo nada relacionado à presente cessão.

Cláusula 5a $5^{\mathrm{a}}$. Toda e qualquer responsabilidade relativa aos créditos ora cedidos são exclusivamente da CEDENTE, respondendo esta por perdas e danos nos termos da legislação vigente caso a CESSIONÁRIA sofra qualquer prejuízo.

\section{CONDIÇÕES GERAIS}

Cláusula $6^{\mathbf{a}}$. O presente contrato passa a vigorar entre as partes acima qualificadas a partir da assinatura do mesmo. 


\section{DO FORO}

Cláusula $7^{\mathbf{a}}$. Para dirimir quaisquer controvérsias oriundas do CONTRATO, as partes elegem o foro da comarca de São Paulo.

E, por estarem assim justos e contratados, firmam o presente instrumento, em duas vias de igual teor, juntamente com 2 (duas) testemunhas.

(Local, data e ano)

(Nome e assinatura do Representante legal da Cedente)

(Nome e assinatura do Representante legal da Cessionária)

(Nome, RG e assinatura da Testemunha 1)

(Nome, RG e assinatura da Testemunha 2) 